\title{
Thermodynamic controls on element partitioning between titanomagnetite and andesitic-dacitic silicate melts
}

\author{
R. H. Sievwright ${ }^{1,2}$ • J. J. Wilkinson ${ }^{2,1}$ - H. St. C. O'Neill ${ }^{3}$ A. J. Berry ${ }^{3,2}$
}

Received: 23 December 2016 / Accepted: 19 June 2017 / Published online: 7 July 2017

(C) The Author(s) 2017. This article is an open access publication

\begin{abstract}
Titanomagnetite-melt partitioning of $\mathrm{Mg}, \mathrm{Mn}$, $\mathrm{Al}, \mathrm{Ti}, \mathrm{Sc}, \mathrm{V}, \mathrm{Co}, \mathrm{Ni}, \mathrm{Cu}, \mathrm{Zn}, \mathrm{Ga}, \mathrm{Zr}, \mathrm{Nb}, \mathrm{Mo}, \mathrm{Hf}$ and Ta was investigated experimentally as a function of oxygen fugacity $\left(f \mathrm{O}_{2}\right)$ and temperature $(T)$ in an andesitic-dacitic bulk-chemical compositional range. In these bulk systems, at constant $\mathrm{T}$, there are strong increases in the titanomagnetite-melt partitioning of the divalent cations $\left(\mathrm{Mg}^{2+}\right.$, $\mathrm{Mn}^{2+}, \mathrm{Co}^{2+}, \mathrm{Ni}^{2+}, \mathrm{Zn}^{2+}$ ) and $\mathrm{Cu}^{2+} / \mathrm{Cu}^{+}$with increasing $f \mathrm{O}_{2}$ between 0.2 and $3.7 \mathrm{log}$ units above the fayalitemagnetite-quartz buffer. This is attributed to a coupling between magnetite crystallisation and melt composition. Although melt structure has been invoked to explain the patterns of mineral-melt partitioning of divalent cations, a more rigorous justification of magnetite-melt partitioning can be derived from thermodynamic principles, which accounts for much of the supposed influence ascribed to melt structure. The presence of magnetite-rich spinel in equilibrium with melt over a range of $f \mathrm{O}_{2}$ implies a reciprocal relationship between $a\left(\mathrm{Fe}^{2+} \mathrm{O}\right)$ and $a\left(\mathrm{Fe}^{3+} \mathrm{O}_{1.5}\right)$ in the melt. We show that this relationship accounts for the observed dependence of titanomagnetite-melt partitioning of divalent cations with $f \mathrm{O}_{2}$ in magnetite-rich spinel. As a result of this, titanomagnetite-melt partitioning of divalent
\end{abstract}

Communicated by Chris Ballhaus.

\section{R. H. Sievwright \\ r.sievwright13@imperial.ac.uk}

1 Department of Earth Science and Engineering, Imperial College London, London SW7 2AZ, UK

2 Department of Earth Sciences, Natural History Museum, Cromwell Road, London SW7 5BD, UK

3 Research School of Earth Sciences, Australian National University, Canberra, ACT 2601, Australia cations is indirectly sensitive to changes in $f_{2}$ in silicic, but less so in mafic bulk systems.

Keywords Magnetite $\cdot$ Trace-element partitioning · Andesite $\cdot$ Dacite $\cdot$ Oxygen fugacity $\cdot$ Petrogenetic indicator

\section{Introduction}

Magnetite is a common liquidus phase in andesitic-dacitic magmas. Here we present new experimental data on the partition coefficients of key elements between magnetiterich spinel and andesitic-dacitic melts which will help in interpreting the petrogenesis of such magmas. Advances in microanalytical techniques, such as laser ablation inductively coupled-plasma mass spectrometry (LA-ICP-MS), have allowed us to determine a large range of trace elements in magnetite quantitatively, including alkali and alkaline earths, metals to transition metals, metalloids, rare-earth elements and others (Dare et al. 2012; Dupuis and Beaudoin 2011; Nadoll et al. 2014). The trace-element chemistry of magnetite and $\mathrm{Fe}-\mathrm{Ti}$ oxides in general has been recognised as a useful tool for interpreting the formation environment of igneous rocks (Dare et al. 2012). Nevertheless, the use of magnetite as a petrogenetic indicator requires full understanding of the controls on element partitioning. To develop a better understanding of the partitioning behaviour of a wide range of elements into magnetite, a set of experiments were conducted at atmospheric pressure $(0.1 \mathrm{MPa})$ as a function of oxygen fugacity $\left(f \mathrm{O}_{2}-\mathrm{FMQ}+0.2\right.$ to $\left.\mathrm{FMQ}+3.7\right)$ and temperature $\left(1070-1120^{\circ} \mathrm{C}\right)$.

Although previous experimental work has studied partitioning of various elements into magnetite as a function of 
different bulk composition, temperature, $\mathrm{fO}_{2}$ and pressure, few studies have covered the range of trace elements detectable using LA-ICP-MS. The growth of crystals large enough to measure low trace-element abundances has previously posed a challenge in experimental petrology, because of the inverse relationship between analysis volume and detection limits. LA-ICP-MS analysis of trace elements requires the crystal size to be large (generally $>20 \mu \mathrm{m}$ ). Previous studies have overcome issues regarding crystal size by doping starting materials to high concentrations, e.g. 10,000 ppm (Nielsen et al. 1994) and analysing magnetite composition by electron probe micro-analysis (EPMA). However, recent work has highlighted that such highly doped systems could in fact overestimate partition coefficients (Righter et al. 2006). Moreover, only a few elements can be added at such levels without compromising the systems bulk chemistry. Fortunately, the development of LA-ICP-MS has significantly enhanced the ease with which the trace-element chemistry of magnetite can be determined. Magnetite associated with magmatic-hydrothermal mineral deposits has been recognised as a potential indicator mineral for fertility (Dare et al. 2014). Such deposits are commonly associated with calc-alkaline, intermediate to felsic magmas. Consequently, a natural calcalkaline andesite and dacite were chosen as starting compositions for this study. Previous work has not investigated in detail the influence of $f \mathrm{O}_{2}$ on the trace-element partitioning of magnetite in an andesitic-dacitic bulk compositional range.

\section{Theoretical background}

Magnetite-melt partitioning relations are not only useful for petrogenetic modelling, they also hold theoretical interest for understanding some of the fundamental principles of trace-element geochemistry. In particular, the very large variation in magnetite-melt partition coefficients observed for many elements over a restricted range of melt compositions at a given temperature and pressure highlights the importance of the "stoichiometric control" in trace-element partitioning. In magnetite, the major-element components providing the stoichiometric control are $\mathrm{Fe}^{2+} \mathrm{O}$ and $\mathrm{Fe}^{3+} \mathrm{O}_{1.5}$, whose activities in the melt, unlike those of silicate minerals, can be varied greatly while still maintaining magnetite on the liquidus. However, this variation in the activities can only occur subject to two constraints, namely the homogeneous equilibrium involving $f \mathrm{O}_{2}$ :

$\mathrm{Fe}^{2+} \mathrm{O}_{\text {(silicate melt) }}+{ }^{1 / 4} \mathrm{O}_{2}=\mathrm{Fe}^{3+} \mathrm{O}_{1.5 \text { (silicate melt) }}$.

And the condition of magnetite saturation:

$\mathrm{Fe}^{2+} \mathrm{O}_{\text {(silicate melt) }}+2 \mathrm{Fe}^{3+} \mathrm{O}_{1.5 \text { (silicate melt })}=\mathrm{Fe}_{3} \mathrm{O}_{4 \text { (spinel) }}$.
These constraints impose a correlation between the variables in magnetite-melt partitioning experiments, which must be deconvoluted by recourse to the underlying thermodynamic principles.

Magnetite has the spinel structure, with the ideal stoichiometry of 3 cations to 4 oxygens per formula unit (i.e. $\mathrm{Fe}_{3} \mathrm{O}_{4}$ ). The deviations from this ideal stoichiometry are very small over the temperature- $f \mathrm{O}_{2}$ range relevant to this study, with $\delta<0.002$ in the formula $\mathrm{Fe}_{3-\delta} \mathrm{O}_{4}$, according to the thermogravimetric measurements of Dieckmann (1982). The spinel structure has two distinct crystallographic sites for cations, one having perfectly regular tetrahedral coordination, the other with almost regular octahedral coordination (e.g. O'Neill and Navrotsky 1983), providing suitable environments for cations with a preference for highly symmetrical coordination environments. For example, $\mathrm{Ni}^{2+}$ and $\mathrm{Cr}^{3+}$ would be expected to partition readily into magnetite because of their large crystal-field stabilisation energies in regular octahedral coordination, but cations with potentially strong Jahn-Teller distortions like $\mathrm{Cr}^{2+}$ are less favoured. The cation distribution in magnetite at room temperature is that of an inverse spinel $\left(\mathrm{Fe}^{3+}\right)_{\text {tet }}\left[\mathrm{Fe}^{2+} \mathrm{Fe}^{3+}\right]_{\text {oct }} \mathrm{O}_{4}$, but at magmatic temperatures it is disordered towards the random distribution, $\left(\mathrm{Fe}_{1 / 3}^{2+} \cdot \mathrm{Fe}_{2 / 3}^{3+}\right)_{\mathrm{tet}}\left[\mathrm{Fe}_{2 / 3}^{2+} \mathrm{Fe}_{4 / 3}^{3+}\right]_{\text {oct }} \mathrm{O}_{4} \quad(\mathrm{Wu}$ and Mason 1981). Its structure therefore provides crystallographic sites suitable for both $2+$ and $3+$ cations in both tetrahedral and octahedral coordination. The presence of $\mathrm{Fe}$ in two valence states $\left(2+\right.$ and $\left.3+^{+}\right)$also facilitates chargebalancing of cations with other valence states. Tetravalent cations such as $\mathrm{Ti}^{4+}$ or $\mathrm{Ge}^{4+}$ can substitute easily onto octahedral or tetrahedral sites, as appropriate, charge-balanced by additional $\mathrm{Fe}^{2+}$, e.g. $\mathrm{Ti}^{4+}+\mathrm{Fe}^{2+}$ for $2 \mathrm{Fe}^{3+}$. In addition to the large range of $2+, 3+$ and $4+$ cations forming ferrite spinels with extensive binary solid solutions with $\mathrm{Fe}_{3} \mathrm{O}_{4}$ (e.g. O'Neill and Navrotsky 1984), there may be extensive incorporation of $1+$ and $5+$ cations. Examples are $\mathrm{Li}^{1+}$, as in the end-member spinel $\mathrm{Li}_{0.5}^{1+} \mathrm{Fe}_{2.5}^{3+} \mathrm{O}_{4}\left(\mathrm{Li}^{+}+\mathrm{Fe}^{3+}\right.$ for 2 $\mathrm{Fe}^{2+}$ ); and $\mathrm{Nb}^{5+}$, for which the phase relations in the system $\mathrm{Fe}-\mathrm{Nb}-\mathrm{O}$ at $1180-1200{ }^{\circ} \mathrm{C}$ show that niobian magnetites may be synthesised with up to $\sim 80 \%$ solid solution towards the hypothetical end-member $\mathrm{Fe}_{2.33}^{2+} \mathrm{Nb}_{0.67}^{5+} \mathrm{O}_{4}$ (Turnock 1966; Katayama 1987).

A distinctive feature of magnetite-melt trace-element partitioning is that while the oxidation states of redoxvariable elements, including $\mathrm{Fe}$, change with $\mathrm{fO}_{2}$ in the melt, they do not change with $f \mathrm{O}_{2}$ in magnetite. The reason is obvious for $\mathrm{Fe}$, because stoichiometry obviously fixes $\mathrm{Fe}^{3+} / \mathrm{Fe}^{2+}$ at 2 for pure magnetite. But this same constraint also applies to some redox-variable trace elements, because its redox speciation will be controlled by an electron-exchange reaction with $\mathrm{Fe}^{2+}$ and $\mathrm{Fe}^{3+}$. A well-known example is $\mathrm{V}$, whose substitution into $\mathrm{Fe}_{3} \mathrm{O}_{4}$ has been studied by thermodynamic measurements on 
the spinel solid solution $\mathrm{FeV}_{2} \mathrm{O}_{4}-\mathrm{Fe}_{3} \mathrm{O}_{4}$ (see review in O'Neill and Navrotsky 1984). Here, the two oxidation states of $\mathrm{V}$ are $3+$ and $4+$, hence the electron-exchange reaction is:

$\mathrm{Fe}^{3+}+\mathrm{V}^{3+}=\mathrm{Fe}^{2+}+\mathrm{V}^{4+}$.

Thus the ratio of $\mathrm{V}^{3+}$ to $\mathrm{V}^{4+}$ in $\mathrm{FeV}_{2} \mathrm{O}_{4}-\mathrm{Fe}_{3} \mathrm{O}_{4}$ spinels is independent of $f \mathrm{O}_{2}$ at a given temperature and pressure; this includes the ratio at infinite dilution. When the free energy of such an electron-exchange reaction is small, the phenomenon contributes a considerable configurational entropy, as seen for example, by the large negative deviations from ideality in $\mathrm{Fe}_{3} \mathrm{O}_{4}-\mathrm{FeV}_{2} \mathrm{O}_{4}$ (O'Neill and Navrotsky 1984). This effect makes $\mathrm{V}$, usually moderately incompatible in common silicate minerals, compatible in magnetite, which has been exploited in petrogenetic hypotheses-see, for example, the discussion in Gill (1981). By contrast, $\mathrm{V}^{3+} / \mathrm{V}^{4+}$ in a spinel without $\mathrm{Fe}$ or other redox-variable major elements, such as $\mathrm{MgAl}_{2} \mathrm{O}_{4}$, can only vary in a way that depends on $f \mathrm{O}_{2}$. For example, in the system $\mathrm{MgO}-\mathrm{Al}_{2} \mathrm{O}_{3}-\mathrm{V}-\mathrm{O}$, the relevant $\mathrm{V}$ components in spinel would be $\mathrm{MgV}_{2}^{3+} \mathrm{O}_{4}$ and $\mathrm{Mg}_{2} \mathrm{~V}^{4+} \mathrm{O}_{4}$, hence the redox speciation of $\mathrm{V}$ in the spinel phase is given by the equilibrium:

$$
0.5 \mathrm{MgV}_{2}^{3+} \mathrm{O}_{4}+1.5 \mathrm{MgO}+0.25 \mathrm{O}_{2}=\mathrm{Mg}_{2} \mathrm{~V}^{4+} \mathrm{O}_{4} .
$$

For a detailed consideration of the thermodynamics of the mineral/melt partitioning of $\mathrm{V}$ as a function of $f \mathrm{O}_{2}$, see Mallmann and O'Neill (2009). Insofar as the spinels of this study are rich in the $\mathrm{Fe}_{3} \mathrm{O}_{4}$ component, the redox speciation of redox-variable elements may be expected to be dominated by electron-exchange reactions and stoichiometry, rather than directly reflecting $f \mathrm{O}_{2}$. Hence the effect of $f \mathrm{O}_{2}$ on the partitioning of redox-variable elements, such as $\mathrm{V}$, $\mathrm{Cu}$ and $\mathrm{Mo}$, between $\mathrm{Fe}_{3} \mathrm{O}_{4}$-rich spinel and melt requires a particularly careful formulation of the underlying thermodynamic relations.

\section{Experimental procedures}

\section{Starting compositions}

Two natural lavas were chosen as experimental starting materials: a natural dacite, 'Japanese Andesite-1' (JA-1); and an andesite 'Andesite 190' (Henderson et al. 1985). Two additional compositions were prepared from these starting materials by adding an extra $5 \mathrm{wt} \% \mathrm{Fe}_{2} \mathrm{O}_{3}$ to promote magnetite saturation. In order to check the bulk chemistry of the starting materials, superliquidus experiments were conducted in a 1 -atm furnace at $1400{ }^{\circ} \mathrm{C}$. The glasses produced were subsequently characterised by EPMA (Table 1).

\section{Choice of trace elements and doping}

The initial starting materials used in this study were not doped with additional trace elements. However, some elements were not detectable with LA-ICP-MS analysis using this approach. Therefore, an additional starting material was prepared by doping the And- $190+\mathrm{Fe}_{2} \mathrm{O}_{3}$ starting material with trace elements, but only in sufficient quantity to raise the expected concentration above the limit of detection for LA-ICP-MS. Expected detection limits based on a 15-micron spot size, were sourced from Nadoll et al. (2014), and expected partition coefficients were derived from existing literature values (Ewart and Griffin 1994; Luhr and Carmichael 1980; Nielsen and Beard 2000). Consequently, $\mathrm{Co}, \mathrm{Ni}, \mathrm{V}, \mathrm{Zn}, \mathrm{Ga}, \mathrm{Nb}, \mathrm{Cu}$ and $\mathrm{Sn}$ were doped at 10 ppm; and Sc, Zr, Hf, Ta, Mo, Pb, Th, U and In
Table 1 Major-element composition of experimental starting materials as determined by EPMA of glasses

\begin{tabular}{|c|c|c|c|c|}
\hline & JA-1 $(n=12)$ & $\mathrm{JA}-1+\mathrm{Fe}_{2} \mathrm{O}_{3}(n=11)$ & And-190 $(n=14)$ & And-190 $+\mathrm{Fe}_{2} \mathrm{O}_{3}(n=8)$ \\
\hline \multicolumn{5}{|c|}{ Major elements (wt\%) } \\
\hline $\mathrm{Na}_{2} \mathrm{O}$ & $3.50 \pm 0.05$ & $3.37 \pm 0.07$ & $4.15 \pm 0.06$ & $3.64 \pm 0.10$ \\
\hline $\mathrm{SiO}_{2}$ & $65.86 \pm 0.52$ & $62.67 \pm 0.93$ & $57.51 \pm 0.28$ & $55.40 \pm 0.7$ \\
\hline $\mathrm{MgO}$ & $1.57 \pm 0.05$ & $1.48 \pm 0.05$ & $3.41 \pm 0.03$ & $3.28 \pm 0.13$ \\
\hline $\mathrm{Al}_{2} \mathrm{O}_{3}$ & $15.10 \pm 0.14$ & $14.37 \pm 0.36$ & $17.79 \pm 0.08$ & $16.74 \pm 0.04$ \\
\hline $\mathrm{P}_{2} \mathrm{O}_{5}$ & $0.13 \pm 0.01$ & $0.12 \pm 0.02$ & $0.16 \pm 0.02$ & $0.14 \pm 0.02$ \\
\hline $\mathrm{K}_{2} \mathrm{O}$ & $0.78 \pm 0.01$ & $0.76 \pm 0.03$ & $1.88 \pm 0.05$ & $1.65 \pm 0.09$ \\
\hline $\mathrm{CaO}$ & $5.75 \pm 0.17$ & $5.47 \pm 0.2$ & $6.60 \pm 0.12$ & $6.60 \pm 0.2$ \\
\hline $\mathrm{TiO}_{2}$ & $0.86 \pm 0.03$ & $0.84 \pm 0.02$ & $0.90 \pm 0.02$ & $0.86 \pm 0.02$ \\
\hline $\mathrm{FeO}^{\mathrm{a}}$ & $6.35 \pm 0.36$ & $10.31 \pm 0.58$ & $6.24 \pm 0.13$ & $10.20 \pm 0.35$ \\
\hline $\mathrm{MnO}$ & $0.15 \pm 0.01$ & $0.12 \pm 0.02$ & $0.12 \pm 0.02$ & $0.12 \pm 0.02$ \\
\hline
\end{tabular}

Errors $=1 \sigma$ standard deviation $n$ number of replicate analysis

a Total $\mathrm{FeO}$ assuming all $\mathrm{Fe}$ is $\mathrm{FeO}$ 
were doped at $100 \mathrm{ppm}$. Trace elements were added to the starting composition as inductively coupled-plasma standard nitrate solutions; the mixture was then dried under a heat lamp and finally re-homogenised in an agate mortar.

\section{Magnetite synthesis method}

Approximately $100 \mathrm{mg}$ of each starting material was mixed with polyethylene oxide and water to form a paste, which was pressed onto $0.3 \mathrm{~mm}$-diameter Pt wire loops. Thin loops were used to avoid Fe loss. The Pt wire loops were then suspended from a Pt chandelier at the end of an alumina rod in the hot zone of a GERO 1-atm vertical furnace at a temperature of $600{ }^{\circ} \mathrm{C}$ and the gas mixing ratios set to produce the desired $f \mathrm{O}_{2}$. Gas mixing ratios were regulated using Celerity FC2900 mass flow controllers (see Burnham et al. (2015) for further experimental details).

Samples were heated to $1250{ }^{\circ} \mathrm{C}$ and held for $9 \mathrm{~h}$, in order to promote homogeneity and equilibration with the imposed $f \mathrm{O}_{2}$. The temperature was then cooled at $20-1190{ }^{\circ} \mathrm{C} / \mathrm{h}$, and subsequently cooled at $3{ }^{\circ} \mathrm{C} / \mathrm{h}$ to the desired temperature where samples were held for $36 \mathrm{~h}$. The temperature was then cycled up at $5{ }^{\circ} \mathrm{C} / \mathrm{h}$ to reduce the number of magnetite nucleation sites, then cooled at $3{ }^{\circ} \mathrm{C} / \mathrm{h}$ again to the desired temperature where samples were held for at least 3 days before drop-quenching into water. The incorporation of a temperature cycle significantly increased magnetite crystal size in experiments with composition And-190 $+\mathrm{Fe}_{2} \mathrm{O}_{3}$ (some $>100$ micron) generating crystals sufficiently large for LA-ICP-MS analysis. It is worth noting that although the absolute $f \mathrm{O}_{2}$ in the furnace varies with temperature, gas mixing ratios used to define the $f \mathrm{O}_{2}$ do not substantially vary the $f \mathrm{O}_{2}$ relative to common $f \mathrm{O}_{2}$ buffers. As a result, only a negligible change in oxidation state $\left(<0.05 \mathrm{Fe}^{3+} / \Sigma \mathrm{Fe}\right)$ of the melt would have occurred during temperature fluctuations in experimental runs. Details of all experimental runs are provided in Table 2.

Temperature inside the furnace was calibrated using a type $\mathrm{B}$ thermocouple and the $\mathrm{fO}_{2}$ calibrated using an SIRO2 solid-state electrode. Temperature is considered accurate to $\pm 1{ }^{\circ} \mathrm{C}$, and $\log f \mathrm{O}_{2}$ is accurate to \pm 0.1 .

\section{Analytical methods}

Run products were examined using a Zeiss EVO 15LS scanning electron microscope in the Imaging and Analysis Centre at the Natural History Museum, London. Energydispersive spectroscopy (EDS) was used in conjunction with back-scattered electron (BSE) imaging to identify the coexisting phases. Analytical conditions were $20 \mathrm{kV}$ accelerating voltage, $3 \mathrm{nA}$ sample current and a $1 \mu \mathrm{m}$ spot size.

A Cameca SX-100 electron microprobe, also at the Natural History Museum, London, was used to measure major
Table 2 Experimental conditions

\begin{tabular}{llllc}
\hline Run $^{\mathrm{a}}$ & Final $T\left({ }^{\circ} \mathrm{C}\right)$ & $\log f \mathrm{O} 2$ & $\Delta \mathrm{FMQ}^{\mathrm{b}}$ & ${\text { Time }(\mathrm{h})^{\mathrm{c}}}^{\mathrm{a}}$ \\
\hline RSM-20 & 1070 & -9.82 & 0.2 & 112 \\
RSM-6 & 1070 & -9.02 & 1 & 78 \\
RSM-11 & 1070 & -8.02 & 2 & 102 \\
RSM-21 & 1070 & -7.02 & 3 & 109 \\
RSM-9 & 1070 & -6.31 & 3.7 & 97 \\
RSM-19 & 1095 & -8.38 & 1.2 & 136 \\
RSM-15 & 1095 & -7.68 & 2 & 121 \\
RSM-12 & 1095 & -6.68 & 3 & 112 \\
RSM-18 & 1095 & -5.98 & 3.7 & 101 \\
RSM-16 & 1120 & -7.16 & 2.2 & 115 \\
RSM-4 & 1120 & -6.36 & 3 & 114 \\
RSM-17 & 1120 & -5.66 & 3.7 & 103 \\
RSM-10 & 1070 & -9.02 & 1 & 344 \\
\hline
\end{tabular}

${ }^{\text {a }}$ For each experimental run, all starting compositions were equilibrated

b $\Delta \mathrm{FMQ}=\log f \mathrm{O}_{2}$ (experiment) $-\log f \mathrm{O}_{2}$ (FMQ buffer); values of FMQ calculated using Hemmingway (1990)

c Time represents dwell time in hours at the final temperature after temperature cycle was completed

and some trace-element contents. Silicon, $\mathrm{Al}, \mathrm{Mg}, \mathrm{Fe}, \mathrm{Ca}$, $\mathrm{P}, \mathrm{Ti}, \mathrm{Mn}, \mathrm{Na}, \mathrm{Cr}$ and $\mathrm{K}$ were analysed for in both titanomagnetite and silicate glass analyses. Alkali elements, such as $\mathrm{Na}$ and $\mathrm{K}$, were included in the analysis of titanomagnetite to be sure no contamination by glass occurred. A $20 \mathrm{kV}$ accelerating voltage, $10 \mathrm{nA}$ sample current and focused electron beam with $1 \mu \mathrm{m}$ spot size were used for titanomagnetite analyses. For glass analyses, analytical conditions were $20 \mathrm{kV}, 2 \mathrm{nA}$ and a defocused $(10-20 \mu \mathrm{m})$ beam in order to minimise migration of alkalis.

Trace elements below the limit of detection of EPMA were obtained by LA-ICP-MS. This was carried out in the LODE laboratory at the Natural History Museum, London, using a New Wave Research $193 \mathrm{~nm}$ excimer laser coupled with an Agilent $7700 \times$ quadrupole ICP-MS. For titanomagnetite analyses, the laser was operated with a pulse rate of $5 \mathrm{~Hz}$, a fluence of $3.5 \mathrm{~J} \mathrm{~cm}^{-2}$, and a spot size of 11-35 $\mu \mathrm{m}$ depending on the crystal size. With decreasing spot size, the limits of detection increase and there is more variability in the data, and thus larger spot sizes were utilised wherever possible. Occasionally, the laser drilled through a target magnetite crystal into the underlying glass; in such cases, only the portion of the signal within titanomagnetite was integrated. Each batch of analyses was bracketed by three analyses of a primary calibration standard (GSD-1 g) and a secondary standard (GSE-1 g). Each batch of magnetite analyses also included one analysis of a Ti-rich magnetite (BC28) studied by Dare et al. (2012). The Fe concentration, determined by EPMA, was used as the 
internal standard. For glass analyses, a pulse rate of $10 \mathrm{~Hz}$, fluence of $3.5 \mathrm{~J} \mathrm{~cm}^{-2}$, and a spot size of $20-50 \mu \mathrm{m}$ were used. GSD-1g was used as the primary calibration standard, and NIST 612 as a secondary standard. Ca determined by EPMA was used as the internal standard. In all cases the analysis duration was $90 \mathrm{~s}$, with the first $30 \mathrm{~s}$ monitoring a gas blank prior to ablation. The isotopes analysed were ${ }^{23} \mathrm{Na},{ }^{24} \mathrm{Mg},{ }^{27} \mathrm{Al},{ }^{29} \mathrm{Si},{ }^{31} \mathrm{P},{ }^{39} \mathrm{~K},{ }^{43} \mathrm{Ca},{ }^{45} \mathrm{Sc},{ }^{49} \mathrm{Ti},{ }^{51} \mathrm{~V},{ }^{52} \mathrm{Cr}$, ${ }^{55} \mathrm{Mn},{ }^{57} \mathrm{Fe},{ }^{59} \mathrm{Co},{ }^{60} \mathrm{Ni},{ }^{63} \mathrm{Cu},{ }^{65} \mathrm{Cu},{ }^{66} \mathrm{Zn},{ }^{69} \mathrm{Ga},{ }^{72} \mathrm{Ge},{ }^{89} \mathrm{Y}$, ${ }^{90} \mathrm{Zr},{ }^{93} \mathrm{Nb},{ }^{95} \mathrm{Mo},{ }^{115} \mathrm{In},{ }^{118} \mathrm{Sn},{ }^{177} \mathrm{Hf},{ }^{181} \mathrm{Ta},{ }^{182} \mathrm{~W},{ }^{208} \mathrm{~Pb}$, ${ }^{232} \mathrm{Th}$ and ${ }^{238} \mathrm{U}$, for both titanomagnetite and glass. Data were reduced using ExLAM 2000 (Zacharias and Wilkinson 2007).

\section{Results}

Experimental charges consist of quenched melt + plagioclase \pm titanomagnetite \pm orthopyroxene \pm clinopyroxene (Fig. 1). At constant $\mathrm{T}$, with increasing $f \mathrm{O}_{2}$, the proportion of quenched melt decreases and the proportion of titanomagnetite and plagioclase increases. With increasing $f \mathrm{O}_{2}$ there is also a decrease in the crystal size of the silicate mineral phases. Addition of $\mathrm{Fe}_{2} \mathrm{O}_{3}$ to both starting compositions significantly increased the modal proportions and average crystal size of titanomagnetite, generating some crystals $>100 \mu \mathrm{m}$ across. Consequently, results in the dacitic bulk system focus on experiments using JA-1 with added $\mathrm{Fe}_{2} \mathrm{O}_{3}$, where titanomagnetite was also present over a greater range of $\mathrm{fO}_{2}$ and temperature. Titanomagnetite crystals exhibit variable morphology and crystal size. Some display euhedral to subhedral equant forms, whereas others are more skeletal.

Melts in all experiments quenched to a homogeneous glass without any evidence of quench crystallisation, apart from one experiment using And-190 $+\mathrm{Fe}_{2} \mathrm{O}_{3}$ at $1070{ }^{\circ} \mathrm{C}$ and $f \mathrm{O}_{2}=\mathrm{FMQ}+3.7$ (RSM-9), in which fine grained plagioclase throughout the glass made it impossible to analyse.

The major-element compositions of titanomagnetite and glass, as well as partition coefficients for some elements analysed with EPMA are listed in Table 3. Titanomagnetite-melt partition coefficients $(D(\mathrm{X}))$, were calculated as (wt $\% \mathrm{X}$ in titanomagnetite)/(wt $\% \mathrm{X}$ in glass). Trace-element concentrations of titanomagnetite and glass, as well as $D(\mathrm{X})$ values, are given in Table 4.

Addition of $\mathrm{Fe}_{2} \mathrm{O}_{3}$ to Andesite-190 does not significantly affect partition coefficients for elements detectable using EPMA (Table 3), namely $\mathrm{Al}, \mathrm{Ti}, \mathrm{Mn}$ and $\mathrm{Mg}$. Using LA-ICP-MS it was also possible to determine Sc, $\mathrm{V}, \mathrm{Co}, \mathrm{Ni}, \mathrm{Zn}, \mathrm{Ga}, \mathrm{Zr}$, and sometimes $\mathrm{Cu}, \mathrm{Mo}, \mathrm{Nb}, \mathrm{Hf}$ and Ta concentrations in titanomagnetite in experiments with

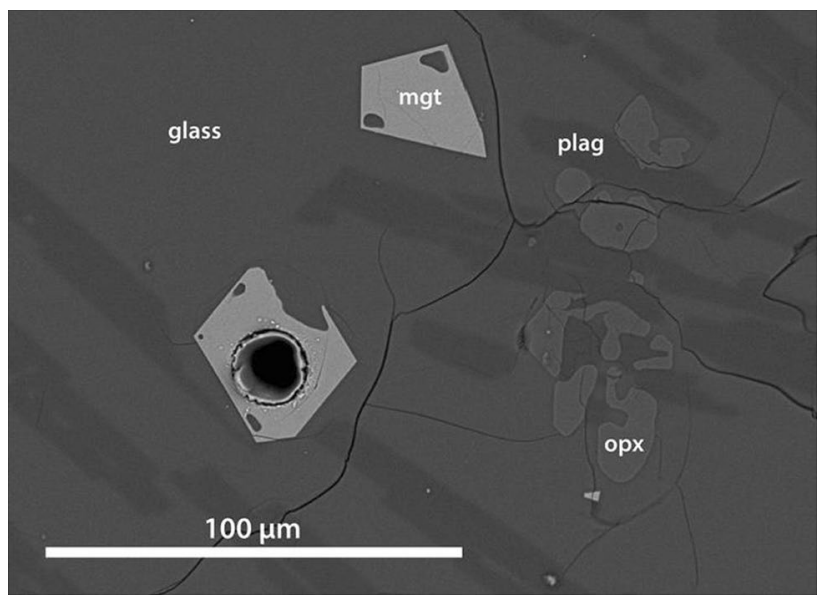

Fig. 1 Back-scattered electron image of titanomagnetite (mgt), plagioclase (plag) and orthopyroxene (opx) in silicate glass synthesised from Andesite-190 $+5 \mathrm{wt} \% \mathrm{Fe}_{2} \mathrm{O}_{3}$ at $1095{ }^{\circ} \mathrm{C}$ and $f \mathrm{O}_{2}=\mathrm{FMQ}+1.2$. The hole is a laser-ablation pit in titanomagnetite

larger titanomagnetite grains (generally higher $f \mathrm{O}_{2}$ ). The concentrations of $\mathrm{Y}, \mathrm{W}, \mathrm{Pb}$, Th and $\mathrm{U}$ were not above their limits of detection by LA-ICP-MS in titanomagnetite in any experiments, including those doped with trace elements, and are therefore not reported. Furthermore, Ge, $\mathrm{Sn}, \mathrm{In}$ and $\mathrm{Pb}$ suffered significant volatile loss, as evinced by lower concentrations than would be expected after doping, so that reliable titanomagnetite-melt partitioning data could not be determined for these elements. Using EPMA, it was possible to detect $\mathrm{Si}, \mathrm{Al}, \mathrm{Mg}, \mathrm{Fe}, \mathrm{Ca}, \mathrm{P}, \mathrm{Ti}$, $\mathrm{Mn}, \mathrm{Na}$ and $\mathrm{K}$ in glass. All other elements reported for glass composition were analysed by LA-ICP-MS. Using GSD-1g as a calibration standard for titanomagnetite and glass produces strong correlation between EPMA and LA-ICP-MS for those elements detectable by both techniques, offering a means to cross-check the accuracy of the LA-ICP-MS data (Fig. 2).

Titanomagnetites are dominated by a magnetite $\left(\mathrm{Fe}_{3} \mathrm{O}_{4}\right)$ component, but also have significant ulvospinel $\left(\mathrm{Fe}_{2} \mathrm{TiO}_{4}\right)$, spinel $\left(\mathrm{MgAl}_{2} \mathrm{O}_{4}\right)$ and magnesioferrite $\left(\mathrm{MgFe}_{2} \mathrm{O}_{4}\right)$ components. Although the same bulk starting compositions were used in all experiments, there are consistent variations in the composition of the titanomagnetite and quenched melt compositions as a function of $f \mathrm{O}_{2}$. Notably, with increasing $f \mathrm{O}_{2}$ there is a decrease in Ti cations per formula unit (cpfu) and increase in $\mathrm{Mg}$ and $\mathrm{Mn}$ cpfu, whilst the total $\mathrm{FeO}^{*}$ and $\mathrm{Al}$ cpfu remain relatively constant. In the melt, there is a marked decrease in $\mathrm{FeO}^{*}$ and $\mathrm{CaO}$, and increase in $\mathrm{SiO}_{2}$ contents with increasing $f \mathrm{O}_{2}$, as a consequence of the increased modal abundance of titanomagnetite and plagioclase. 


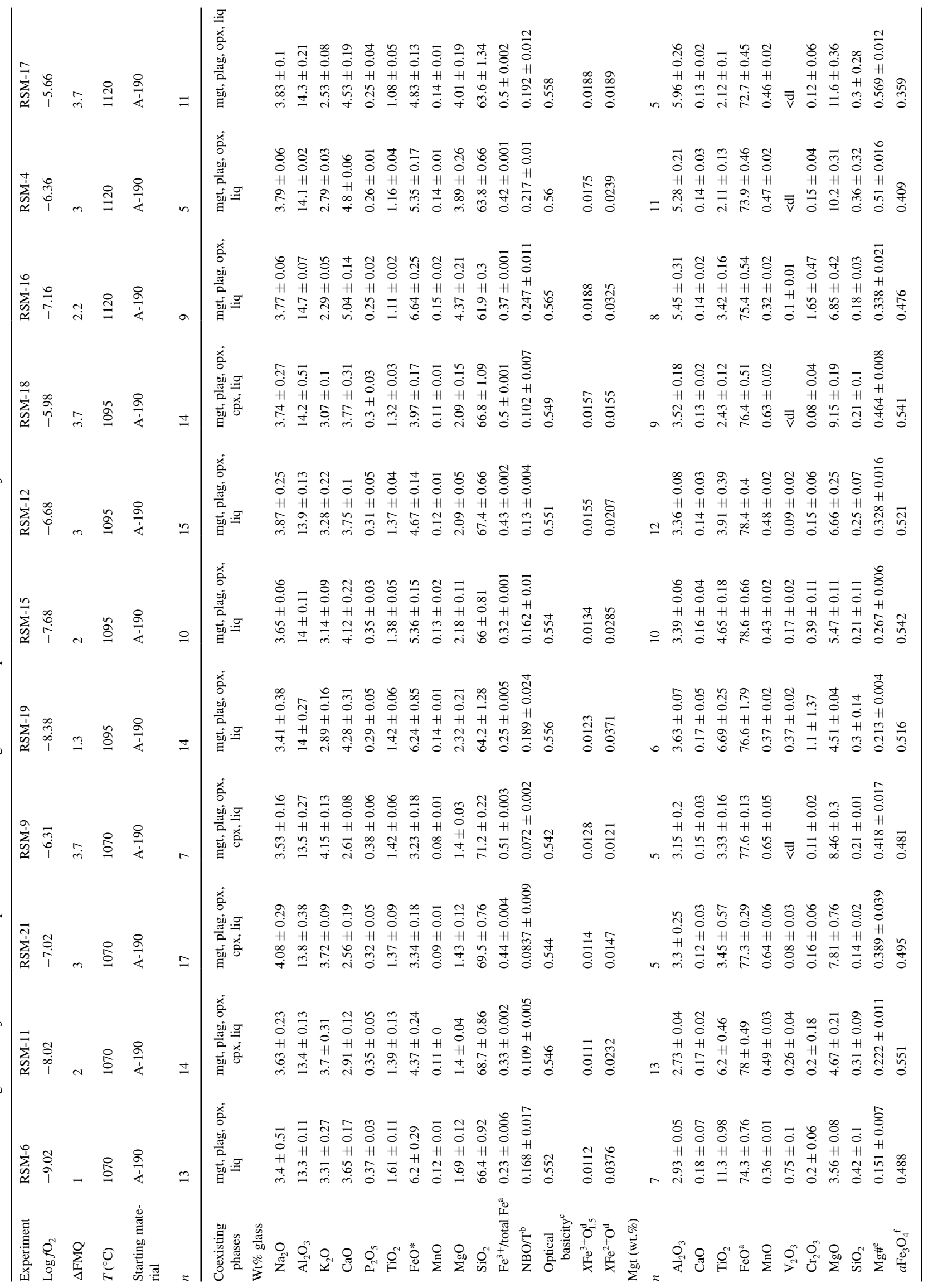




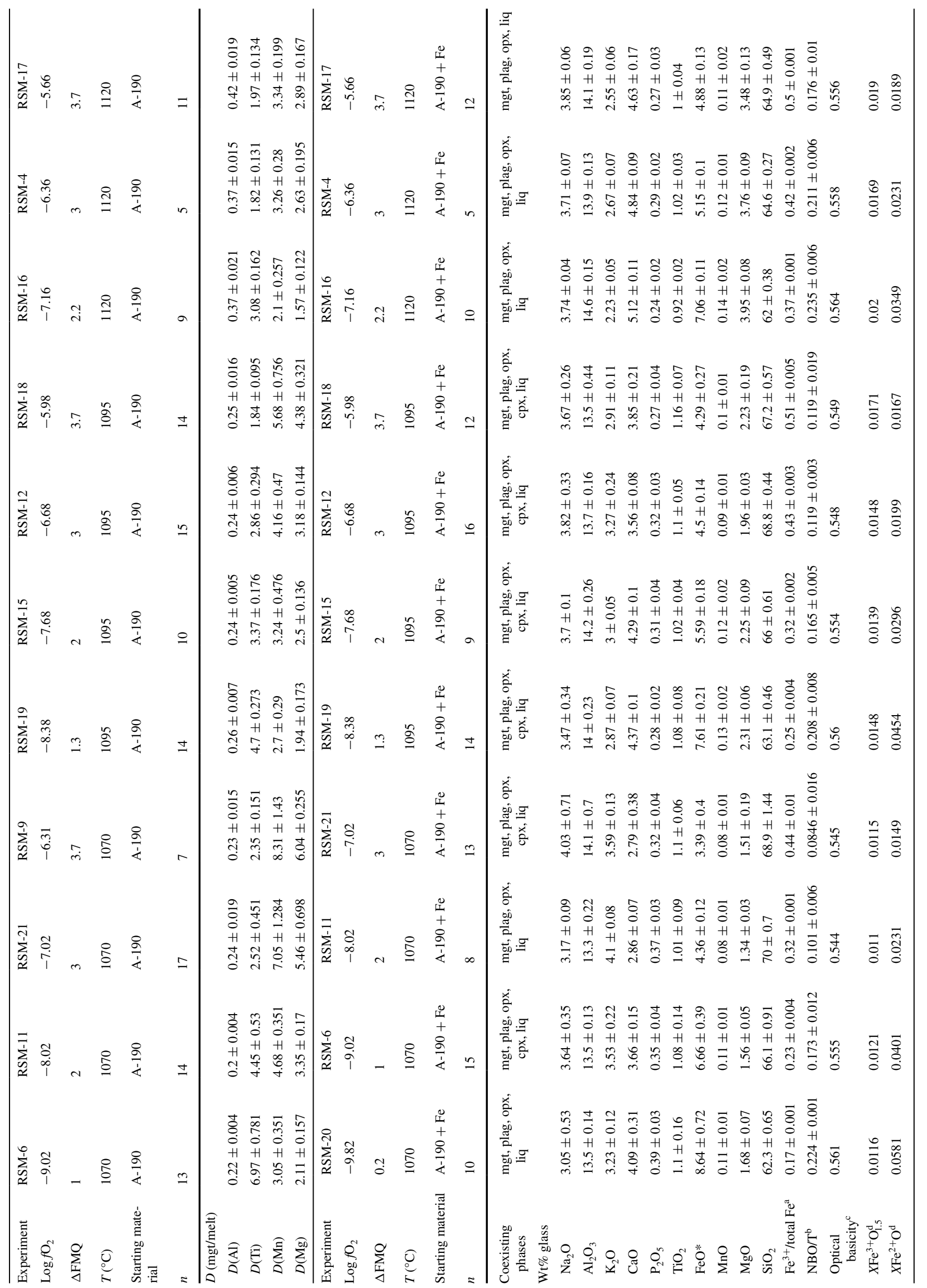




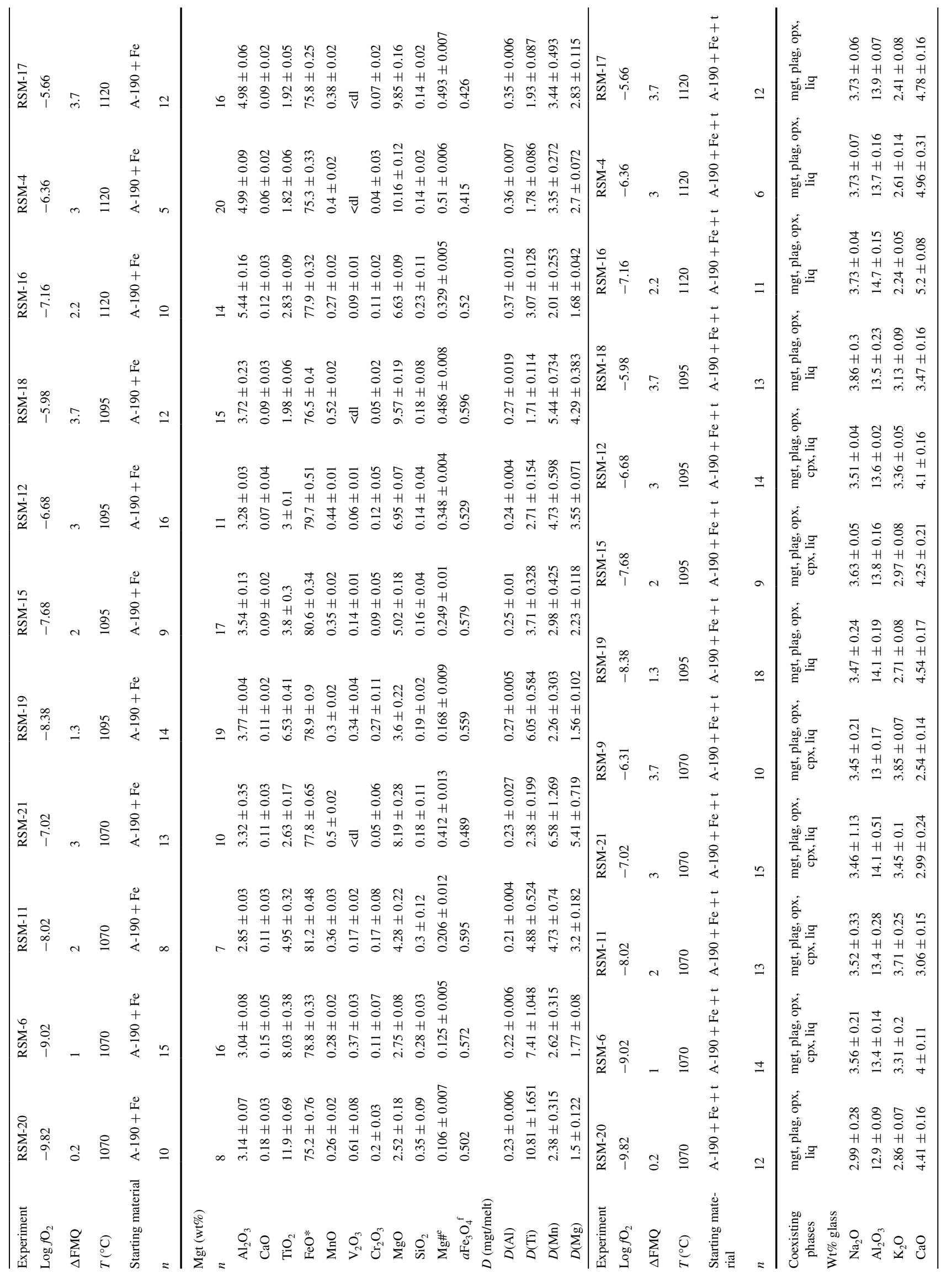




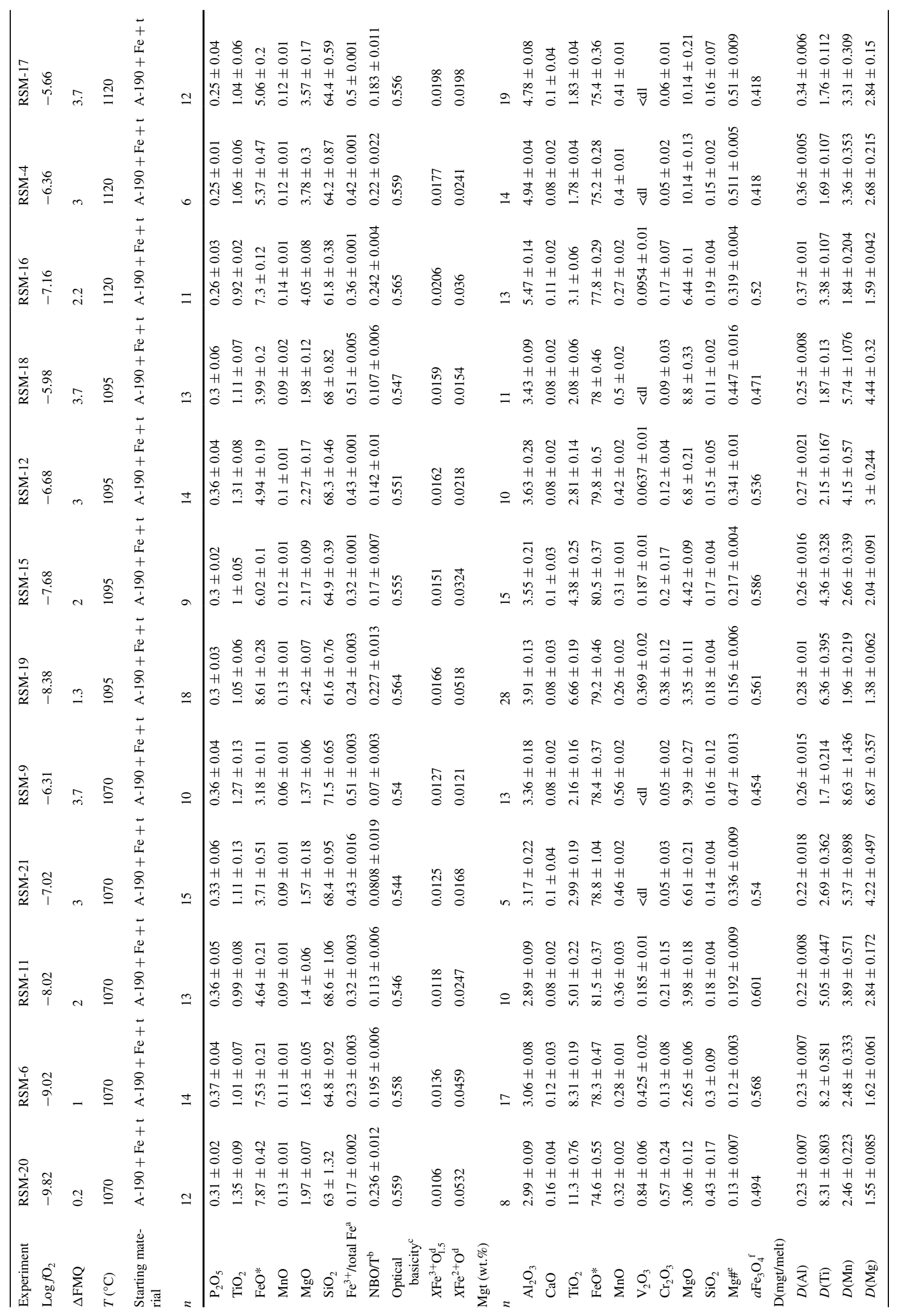




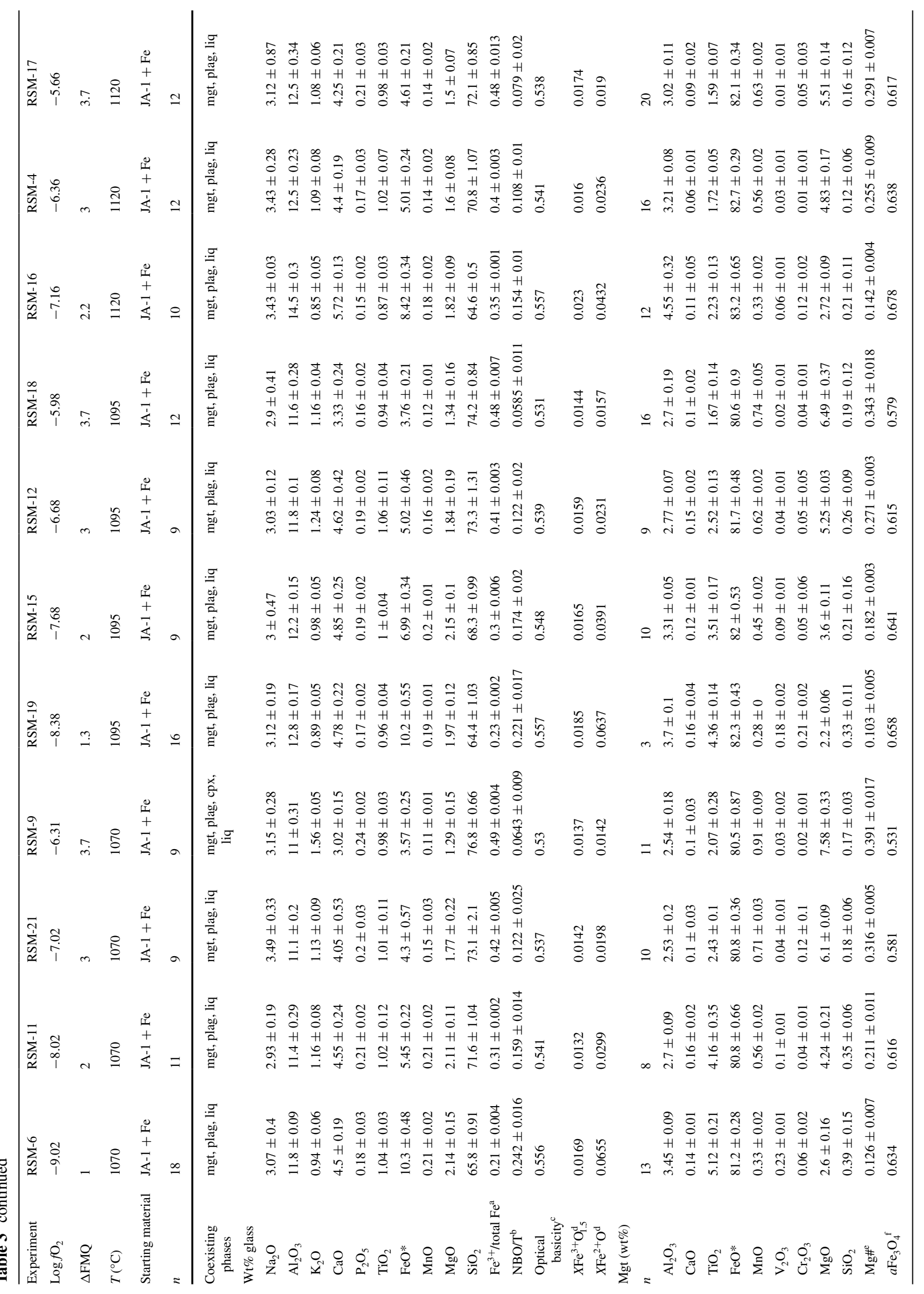




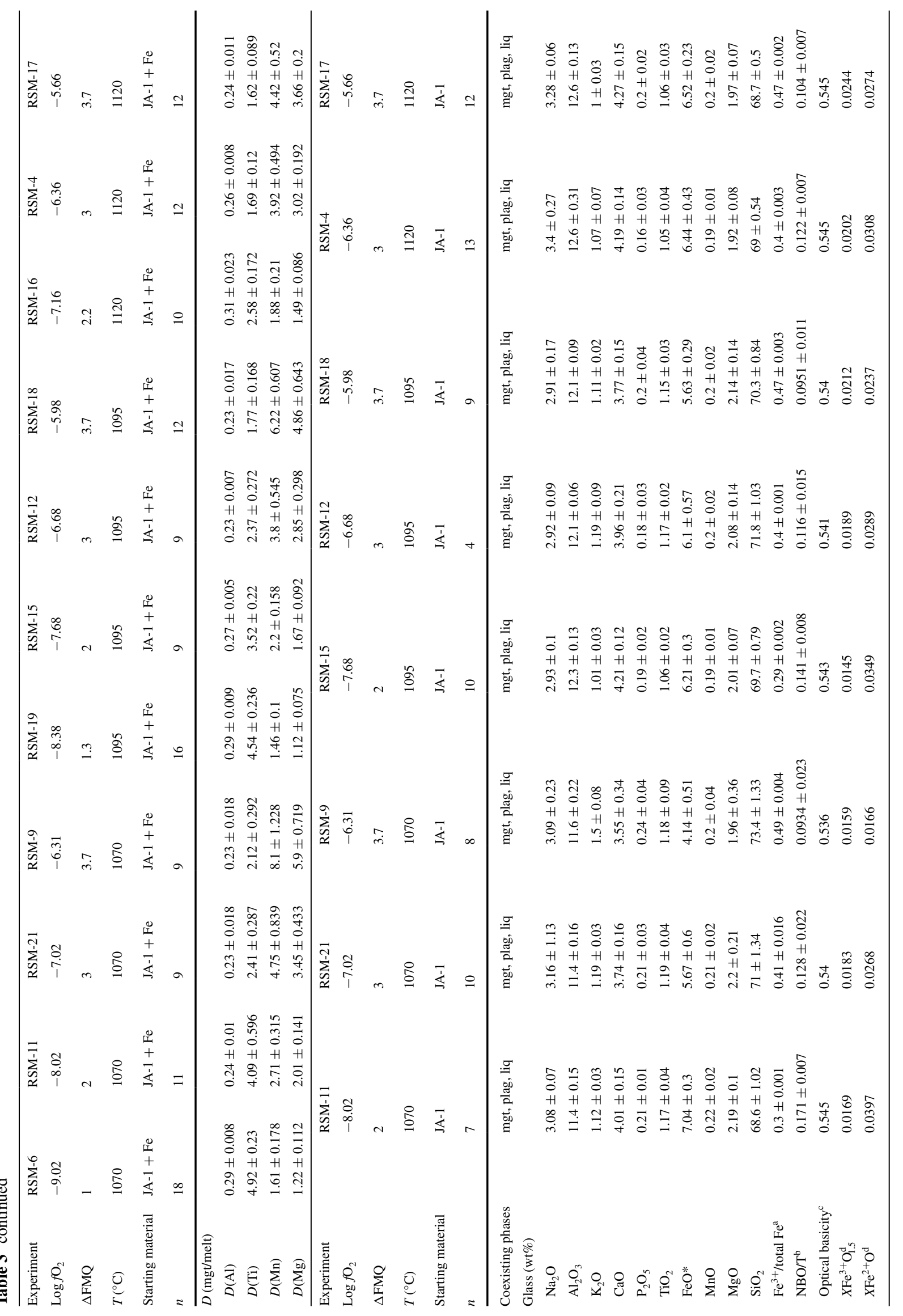




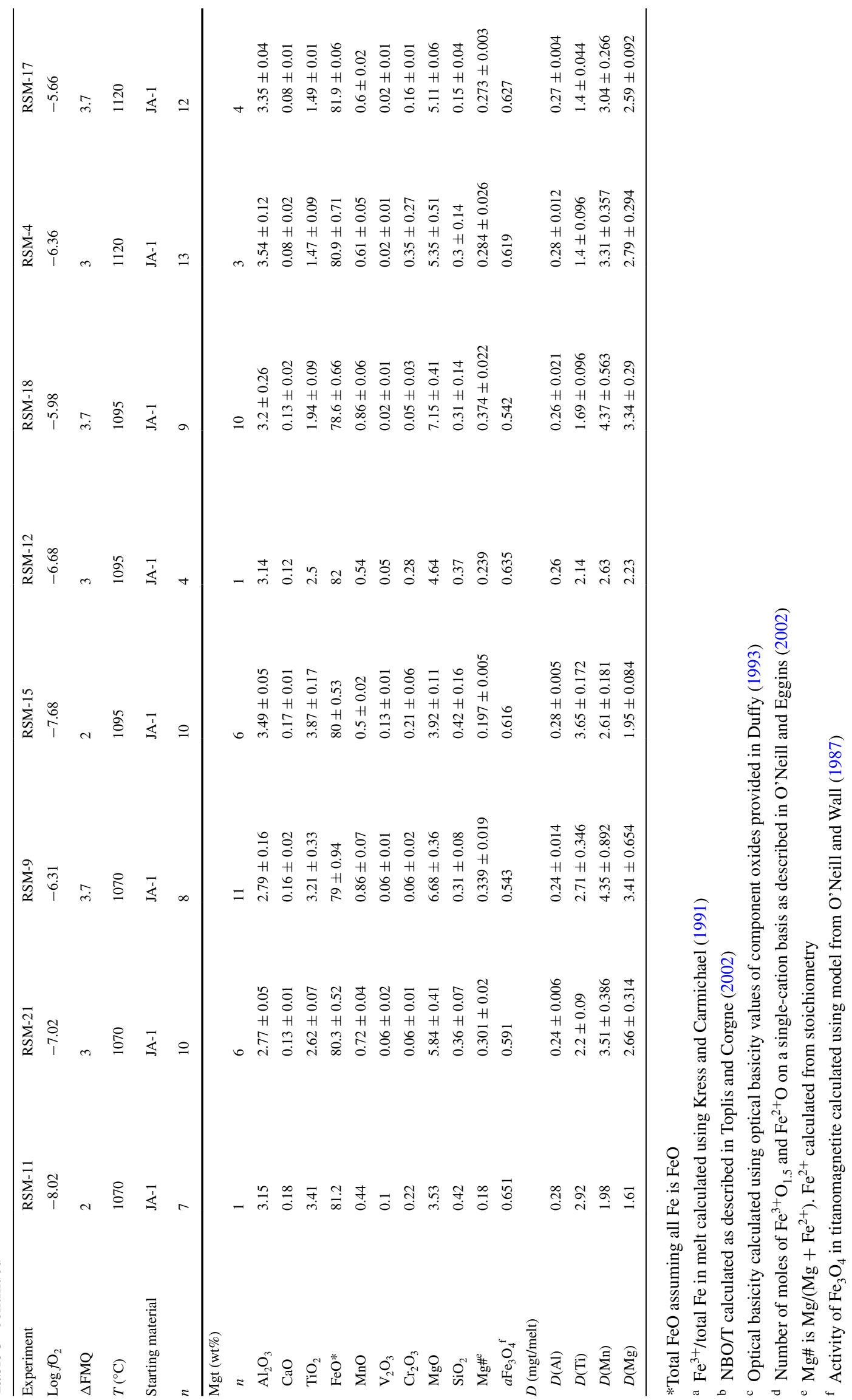




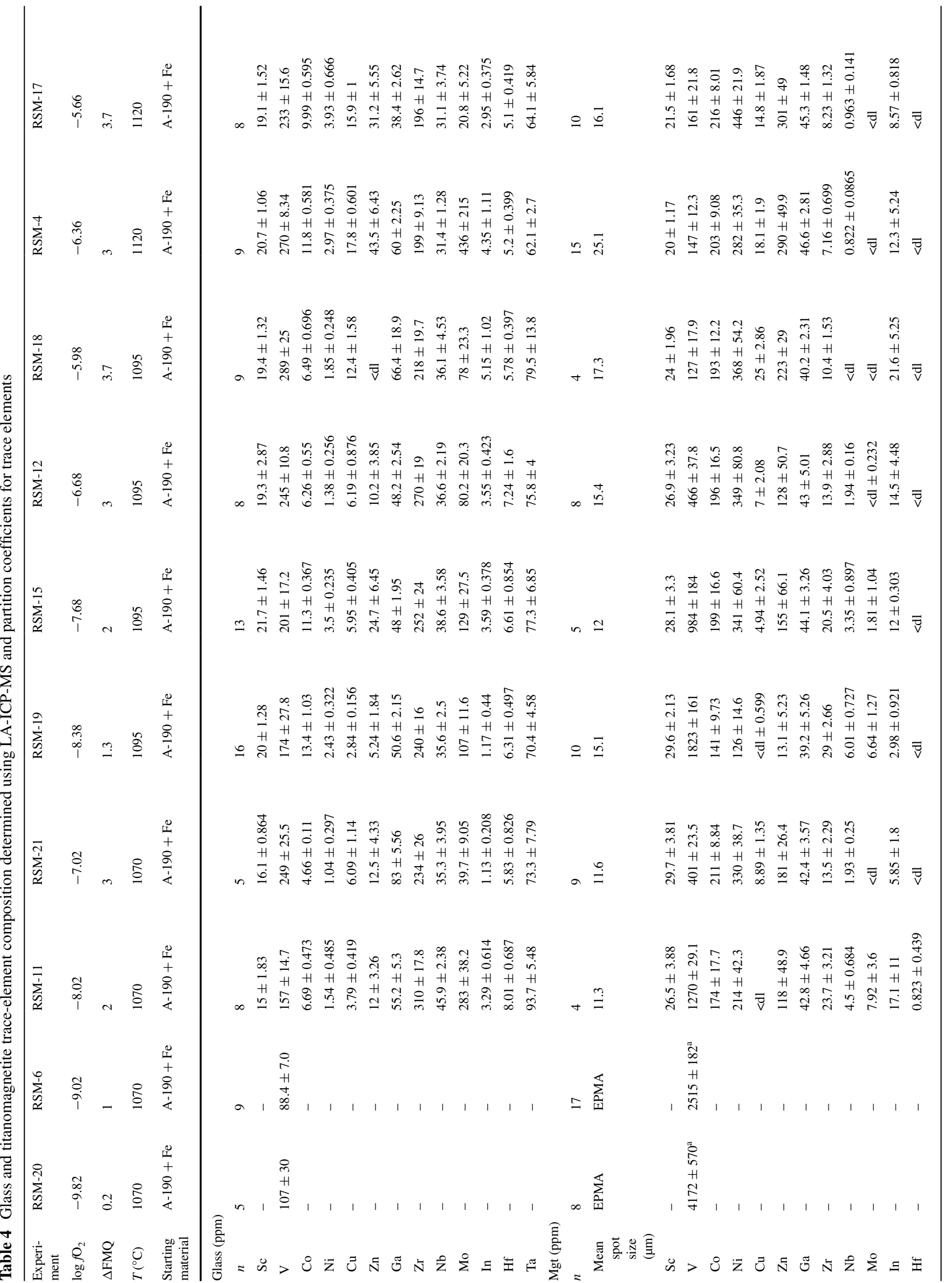




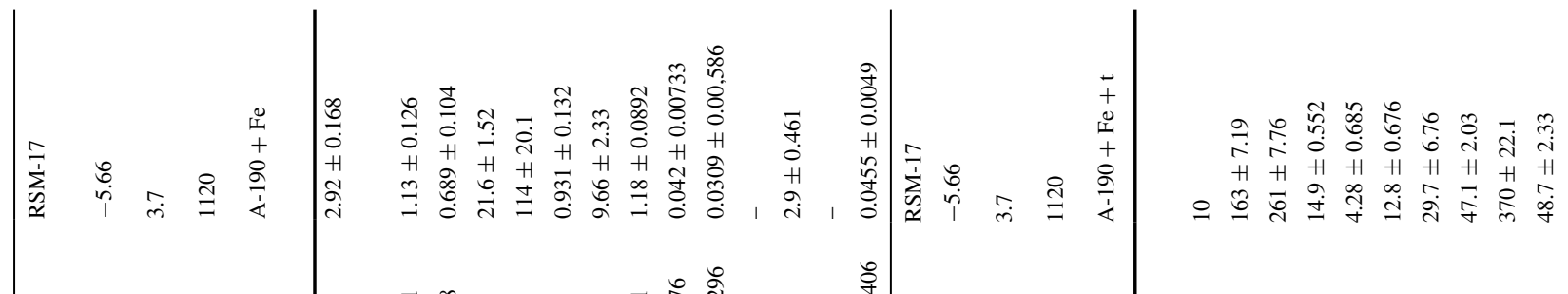

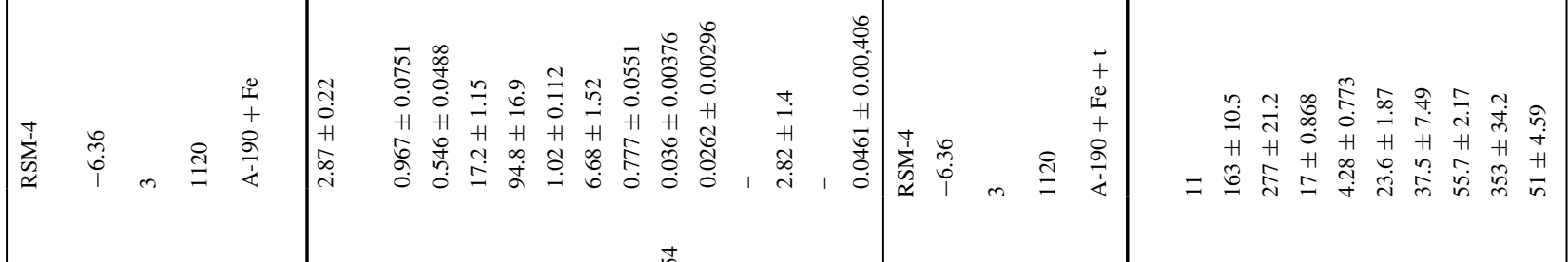

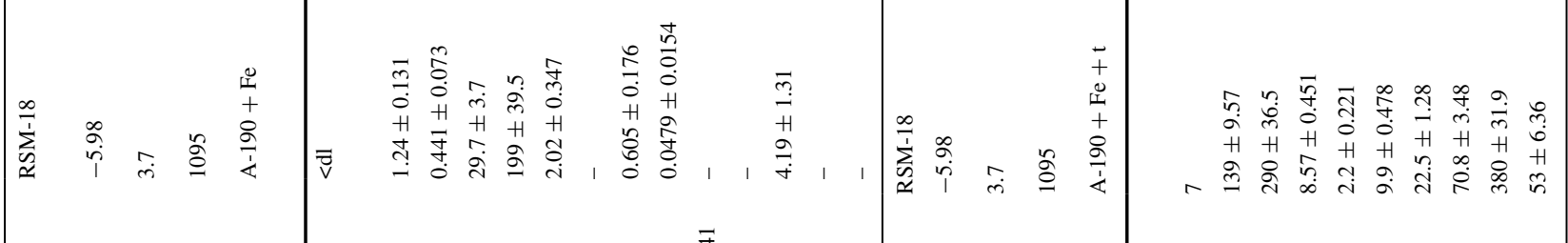

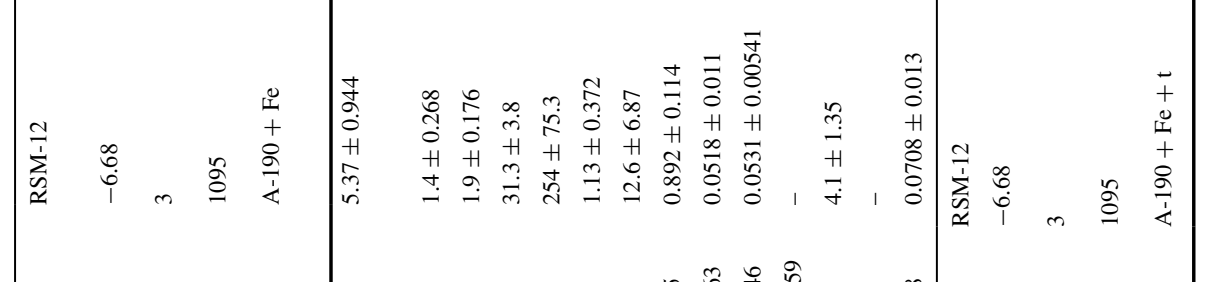

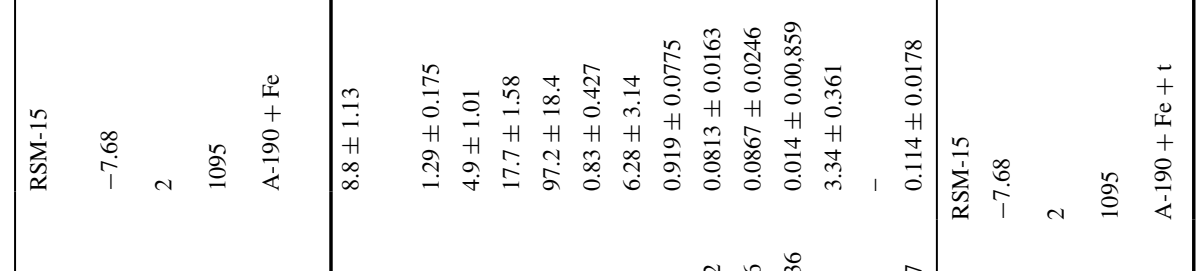

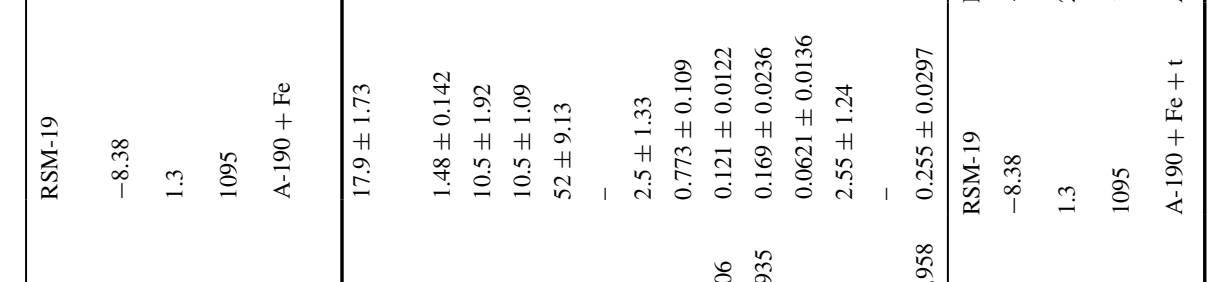

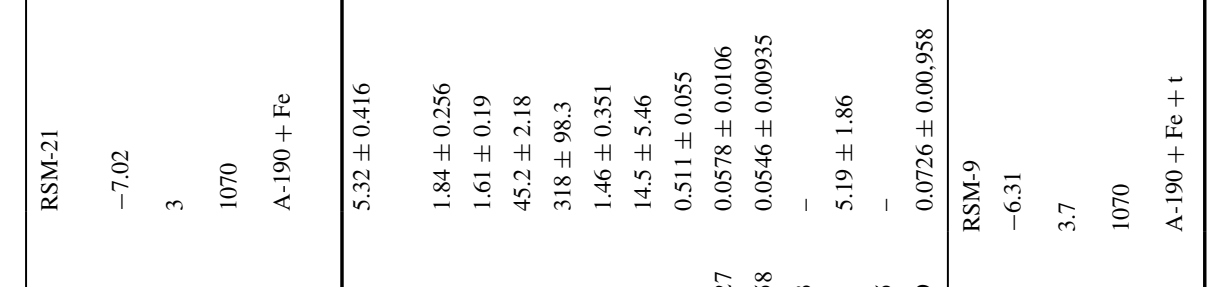

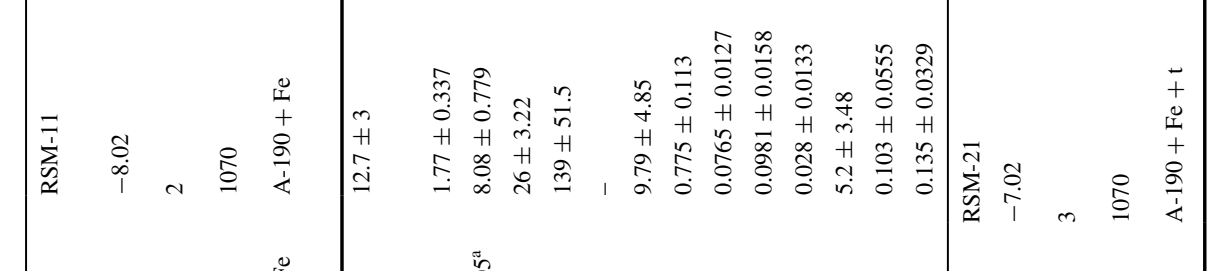

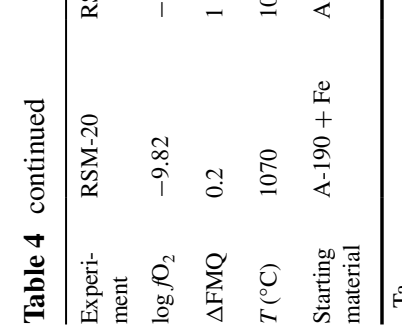

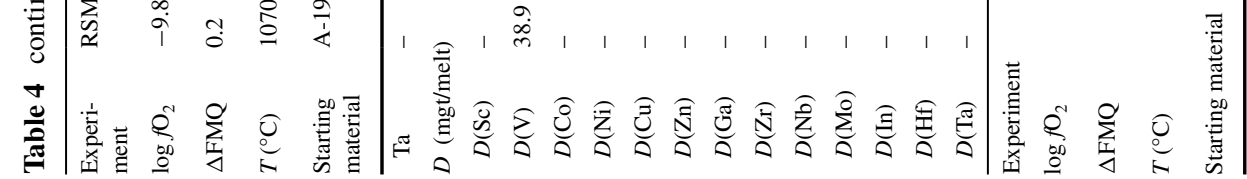

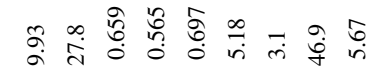

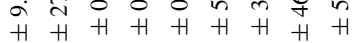

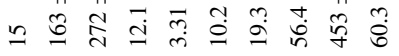

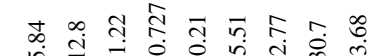

$$
\begin{aligned}
& \text { H H H H H H H H H }
\end{aligned}
$$

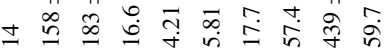

$$
\begin{aligned}
& \text { సิ } \\
& \mathrm{H} H \mathrm{H} H \mathrm{H} H \vec{H}
\end{aligned}
$$

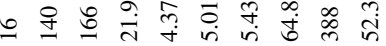

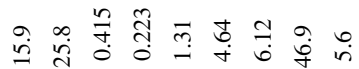

$$
\begin{aligned}
& \text { H H H H H H H H }
\end{aligned}
$$

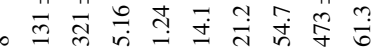

$$
\begin{aligned}
& \text { 굴 }
\end{aligned}
$$

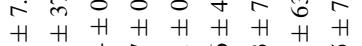

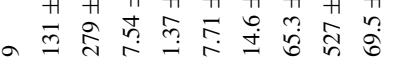

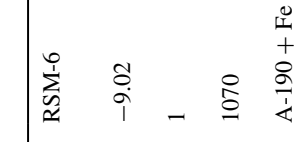

$$
\begin{aligned}
& \stackrel{\text { ig }}{\text { i }}
\end{aligned}
$$

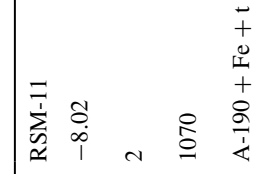




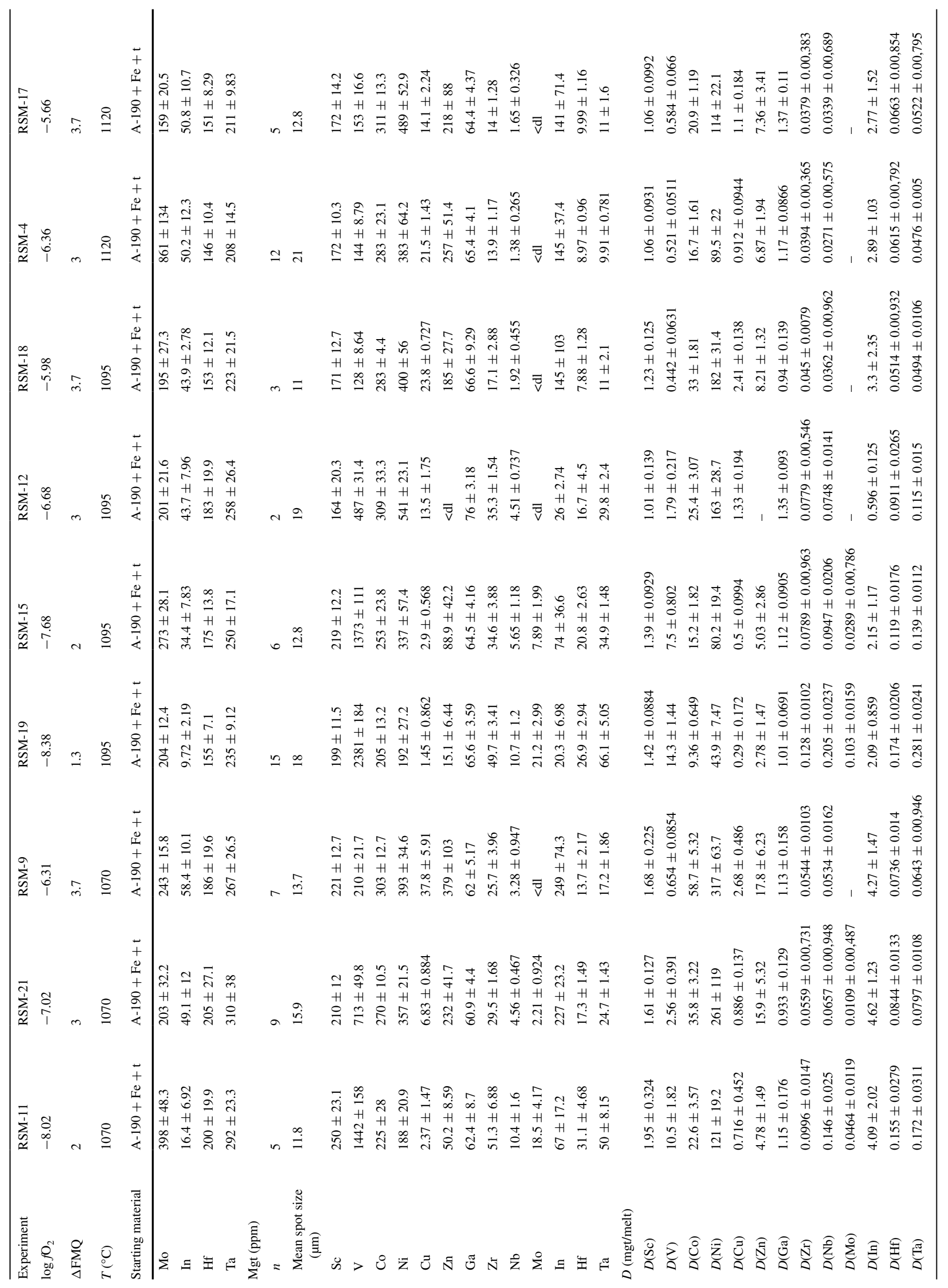




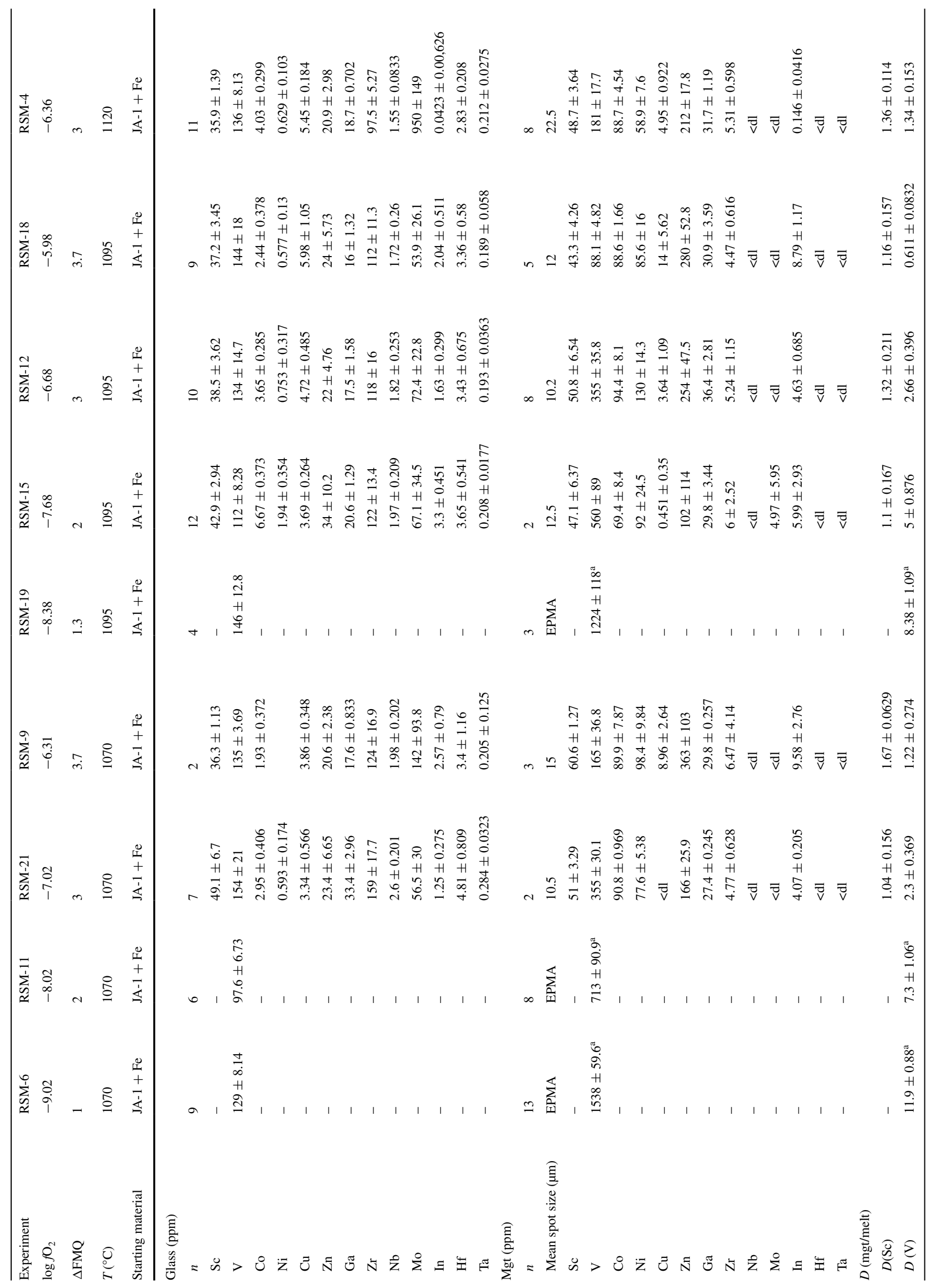




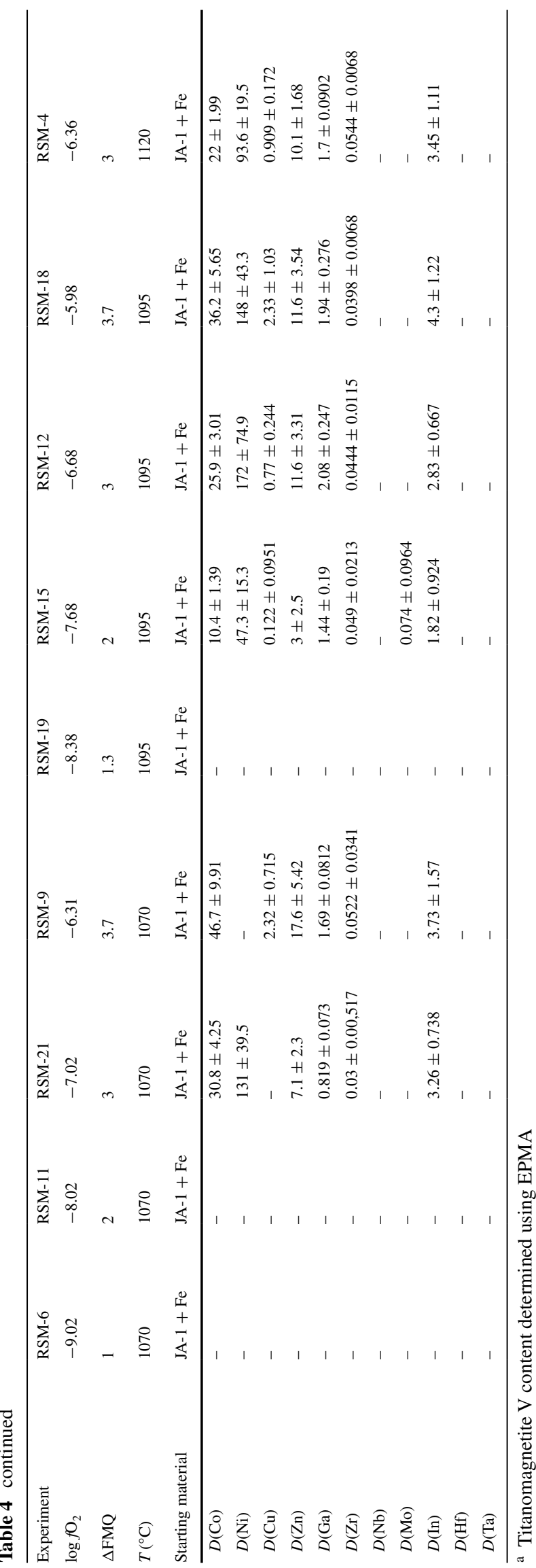

\section{Attainment of equilibrium}

Experiments conducted for longer durations ( $>14$ days) indicate that the dwell time at the final temperature (3 days) was sufficient to provide a close approach to equilibrium (Fig. 3). Incorporation of a temperature cycle was also shown to have no significant impact on the experimentally determined partition coefficients for elements detected using EPMA (Fig. 3). BSE images of the experimental charges do not reveal any compositional zoning in titanomagnetite or glass (Fig. 1), which is supported by homogeneous compositions determined in line traverses across grains, and low standard deviations for replicate analyses of both titanomagnetite and glass. Collectively, these data suggest that equilibrium was attained in all experiments.

Loss of certain elements during an experiment could present issues when determining equilibrium partition coefficients. For example, $\mathrm{Ni}, \mathrm{Co}$ and $\mathrm{Cu}$ could be susceptible to alloying with the $\mathrm{Pt}$ wire, and $\mathrm{Zn}$ could be lost through volatility. For $\mathrm{Co}$ and $\mathrm{Ni}$, concentrations in the glass do not decrease with decreasing $f \mathrm{O}_{2}$, which indicates that there was no significant loss of these elements during the experiments. There is a slight decrease in $\mathrm{Cu}$ concentration with decreasing $f \mathrm{O}_{2}$ suggesting that there was minor loss during the experiments. Zinc concentrations are also lowest at low $f \mathrm{O}_{2}$, which suggests there was some volatile loss at low $f \mathrm{O}_{2}$. Thus values of $D(\mathrm{Cu})$ and $D(\mathrm{Zn})$ should be viewed with caution.

\section{Titanomagnetite-melt partitioning}

Magnesium, Mn, $\mathrm{Zn}, \mathrm{Co}$, and $\mathrm{Ni}$ are assumed to partition as divalent cations over the range of experimental conditions studied. Values of $D(\mathrm{Mg}), D(\mathrm{Mn}), D(\mathrm{Zn}), D(\mathrm{Co})$ and $D(\mathrm{Ni})$ are well correlated with each other, suggesting that there is a common factor controlling their partitioning (Fig. 4). Nickel is the most compatible divalent cation studied, followed by $\mathrm{Co}, \mathrm{Zn}, \mathrm{Mn}$, then $\mathrm{Mg}$. At constant $\Delta \mathrm{FMQ}$, the partition coefficients for divalent cations are greater at lower temperature. For $f \mathrm{O}_{2}$ values between FMQ +0.2 and FMQ + 3.7, titanomagnetite-melt partitioning of the divalent cations (e.g. $\mathrm{Mg}$ and $\mathrm{Mn}$ ) increases with increasing $f \mathrm{O}_{2}$, which is particularly pronounced at lower temperature (Fig. 5a). This variation in the partitioning of these isovalent divalent cations with $f \mathrm{O}_{2}$ cannot be attributed to a change in valence. Interestingly, an increase in partition coefficient for $\mathrm{Mn}$, Co and Ni with increasing $\mathrm{fO}_{2}$ was not observed in studies by Righter et al. (2006) and Toplis and Corgne (2002), who both investigated more mafic bulk systems $\left(\mathrm{SiO}_{2} \leq 49.5\right.$ wt. \%).

Titanomagnetite-melt partitioning of $\mathrm{Al}$ shows no clear dependence on $f \mathrm{O}_{2}$, but $\mathrm{Al}$ is more strongly partitioned into titanomagnetite at higher temperature $\left(T>1095{ }^{\circ} \mathrm{C}\right)$ 
Fig. 2 Titanomagnetite-melt partition coefficients determined using LA-ICP-MS and EPMA analyses for a Mn, b Ti, and c Mg. Errors bars are $1 \sigma$ of multiple analyses. Grey line is $1: 1$

(Fig. 5b). Nevertheless, the influence of temperature on $D(\mathrm{Al})$ is weaker than for $D(\mathrm{Mg}), D(\mathrm{Mn}), D(\mathrm{Zn}), D(\mathrm{Co})$ and $D(\mathrm{Ni})$. There is not a strong bulk compositional dependence with similar $D(\mathrm{Al})$ values observed in ferrobasaltic (Toplis and Corgne 2002), andesitic and dacitic bulk systems (this study) at comparable temperature and $f \mathrm{O}_{2}$. Gallium is weakly compatible in titanomagnetite $(D(\mathrm{Ga})$ between 0.93 and 1.36), but exhibits no clear trend in titanomagnetite-melt partitioning with either $f \mathrm{O}_{2}$ or temperature. The $D(\mathrm{Ga})$ values obtained are somewhat lower than those reported for Cr-rich spinel at higher temperature by Horn et al. (1994) $\left(\mathrm{D}(\mathrm{Ga})>2.49\right.$ at $\left.T>1235^{\circ} \mathrm{C}\right)$, suggesting $\mathrm{Ga}$ is more strongly partitioned at higher temperature, although the higher $D(\mathrm{Ga})$ could also be induced by the contrasting spinel composition.

Titanomagnetite-melt partitioning of Sc also shows no clear dependence on $f \mathrm{O}_{2}$. No relationship between $D(\mathrm{Ti})$ and $D(\mathrm{Sc})$ is apparent in our data as previously reported by some studies (e.g. Horn et al. 1994; Nielsen et al. 1994). Although Cr was detectable with EPMA analysis in titanomagnetite, $\mathrm{Cr}$ in the glass was below detection limit with LA-ICP-MS, which meant $D(\mathrm{Cr})$ could not be determined.

Copper is moderately incompatible to compatible in titanomagnetite with $D(\mathrm{Cu})$ ranging from 0.29 to 2.68. Similar to the divalent cations, at constant $f \mathrm{O}_{2}, D(\mathrm{Cu})$ is greater at lower temperature, and at constant $\mathrm{T}, D(\mathrm{Cu})$ increases with increasing $f \mathrm{O}_{2}$. For example, at $1095{ }^{\circ} \mathrm{C}, D(\mathrm{Cu})$ increases from 0.29 to 2.41 between FMQ $+1.3<f \mathrm{O}_{2}<\mathrm{FMQ}+3.7$ in the And-190 $+\mathrm{Fe}_{2} \mathrm{O}_{3}+$ trace bulk system. Our values for $D(\mathrm{Cu})$ are in agreement with those reported for $\mathrm{Cr}, \mathrm{Al}$, and $\mathrm{Fe}$ spinels crystallised at pressure in a hydrous system (Liu et al. 2014, 2015) and also similarly exhibit an increase $D(\mathrm{Cu})$ with increasing $f \mathrm{O}_{2}$ and $\mathrm{Fe}^{3+}$ cpfu. However, there is no increase in $D(\mathrm{Cu})$ with increasing Ti cpfu as was observed by Liu et al. (2015) and Simon et al. (2008) in dacitic and rhyolitic bulk compositions, respectively.

At $f \mathrm{O}_{2}<\mathrm{FMQ}+3, D(\mathrm{Ti})$ exhibits a strong decrease with increasing $f \mathrm{O}_{2}$ (Fig. 5c). At constant $\log f \mathrm{O}_{2}$, there is no significant change in $D(\mathrm{Ti})$ with temperature. This finding differs from earlier studies which suggested that Ti is more strongly partitioned at higher temperature (e.g. Nielsen et al. 1994). Comparing results from this work with those from experiments using a more mafic starting material (e.g. Toplis and Corgne 2002), shows a large degree of overlap suggesting that bulk composition does not have a significant effect on $D(\mathrm{Ti})$. However, this breaks down at $\mathrm{fO}_{2}<\mathrm{FMQ}+1$, where $\mathrm{Ti}$ is more strongly partitioned in more silicic (andesitic-dacitic) bulk systems.
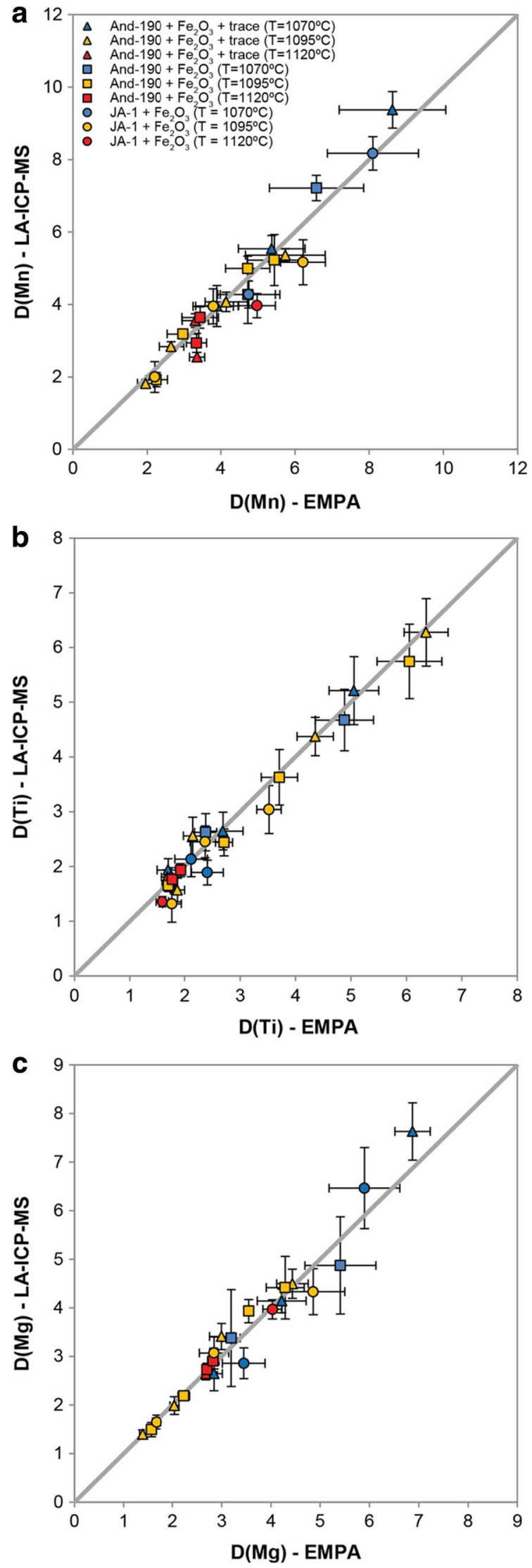
Vanadium is strongly compatible at low $f \mathrm{O}_{2}(\mathrm{D}(\mathrm{V})=38.9$ at $f \mathrm{O}_{2}=\mathrm{FMQ}+0.2$ and $T=1070{ }^{\circ} \mathrm{C}$ using And$190+\mathrm{Fe}_{2} \mathrm{O}_{3}$ ), but becomes incompatible at $f \mathrm{O}_{2}>\mathrm{FMQ}+3$ $\left(\mathrm{D}(\mathrm{V})=0.65\right.$ at $f \mathrm{O}_{2}=\mathrm{FMQ}+3.7$ and $T=1070{ }^{\circ} \mathrm{C}$ using

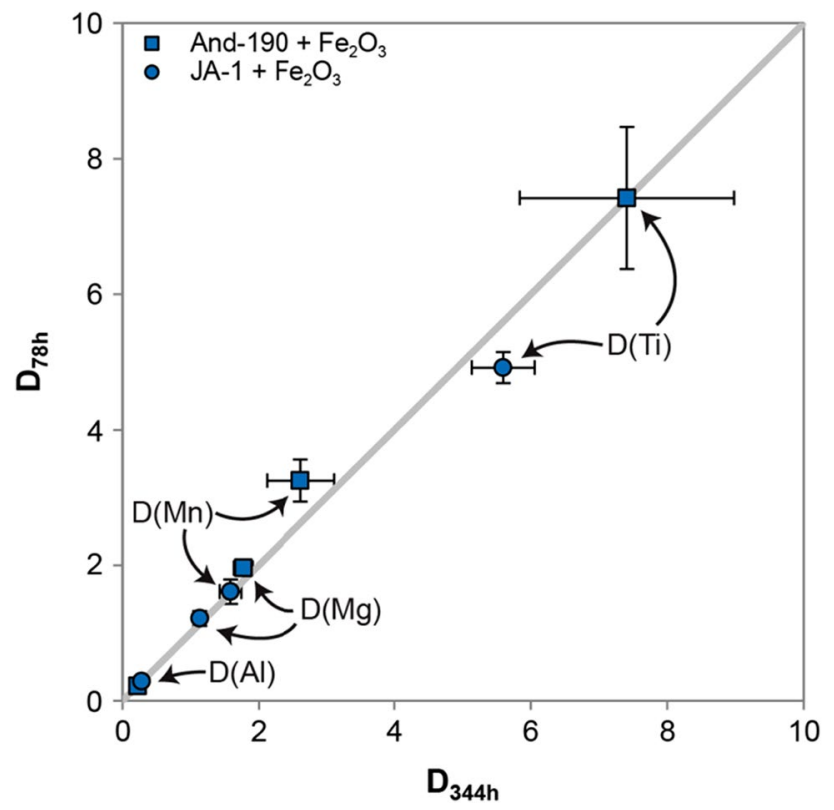

Fig. 3 Experimentally determined partition coefficients $(D)$ from an experiment with a dwell time of $78 \mathrm{~h}$ vs. $D$ values determined from an experiment with a dwell time of $344 \mathrm{~h}$. Both experiments were conducted at $1070{ }^{\circ} \mathrm{C}$ and $f \mathrm{O}_{2}=\mathrm{FMQ}+1$ and included both $\mathrm{JA}-1+\mathrm{Fe}_{2} \mathrm{O}_{3}$ and And-190 $+\mathrm{Fe}_{2} \mathrm{O}_{3}$. No temperature cycle was used in the longer 344-h experiment. Grey line is 1:1 and error bars $=1 \sigma$
And-190 $+\mathrm{Fe}_{2} \mathrm{O}_{3}+$ trace) Thus, at constant temperature, $D(\mathrm{~V})$ decreases with increasing $f \mathrm{O}_{2}$, exhibiting partitioning behaviour like Ti. There is also a slight increase in $D(\mathrm{~V})$ with decreasing temperature and constant $f \mathrm{O}_{2}$. Although titanomagnetite crystals in experiments conducted at $f \mathrm{O}_{2} \leq \mathrm{FMQ}+1$ were generally too small to analyse by LA-ICP-MS, because V contents increase strongly with decreasing $f \mathrm{O}_{2}$ it was possible to measure the $\mathrm{V}$ content of titanomagnetite using EPMA for these experiments. The $\mathrm{V}$ contents of the glasses were determined using LA-ICP-MS for some experiments at low $f^{\mathrm{O}_{2}}$ using And-190 $+\mathrm{Fe}_{2} \mathrm{O}_{3}$. The derived $D(\mathrm{~V})$ values are similar to those reported for the more mafic bulk compositions studied by Toplis and Corgne (2002) (Fig. 5d). Similar to $D(\mathrm{Ti})$, $D(\mathrm{~V})$ does not decrease significantly at $f \mathrm{O}_{2}>\mathrm{FMQ}+3$.

The titanomagnetite-melt partition coefficients for the high field strength elements (HFSE), $\mathrm{Zr}, \mathrm{Hf}, \mathrm{Nb}$ and $\mathrm{Ta}$, all correlate positively (Fig. 6). As for the divalent cations, this suggests a common factor controls their mineral-melt partitioning. Tantalum is the most compatible HFSE cation studied, followed by $\mathrm{Nb}, \mathrm{Hf}$, then $\mathrm{Zr}$. With increasing $f \mathrm{O}_{2}$, $D(\mathrm{Zr}) / D(\mathrm{Nb})$ and $D(\mathrm{Hf}) / D(\mathrm{Ta})$ increase, suggesting the incorporation of $4+$ cations into titanomagnetite is increasingly favoured. For example, at $T=1095^{\circ} \mathrm{C}, D(\mathrm{Zr}) / \mathrm{D}(\mathrm{Nb})$ increases from $0.63 \pm 0.088$ at $f \mathrm{O}_{2}=\mathrm{FMQ}+1.3$ to $1.25 \pm 0.39$ at $f \mathrm{O}_{2}=\mathrm{FMQ}+3.7$ in experiments using And$190+\mathrm{Fe}_{2} \mathrm{O}_{3}+$ trace starting material. There is a linear correlation between $D(\mathrm{Ta})$ and $D(\mathrm{Nb})$, although Ta is slightly more compatible in magnetite than $\mathrm{Nb}$, despite the similarity in ionic radii and ionic charge $(+5)$ of these two elements. Ta is also partitioned into titanomagnetite more strongly relative

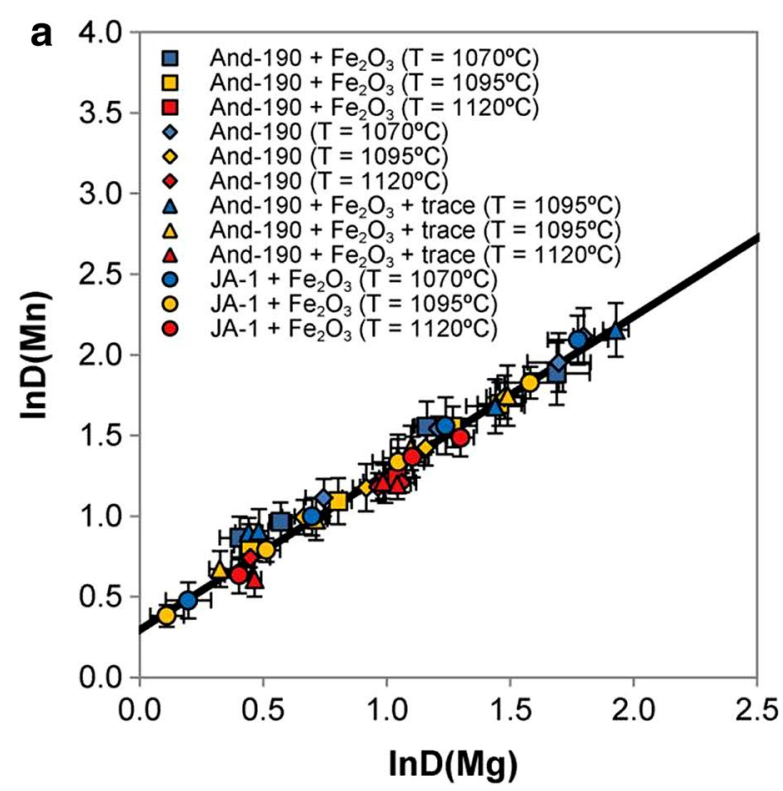

Fig. 4 Natural log of titanomagnetite-melt partition coefficients of a $\mathrm{Mn}, \mathbf{b} \mathrm{Co}, \mathbf{c} \mathrm{Zn}, \mathbf{d ~ N i}$ and $\mathbf{e ~} \mathrm{Cu}$ as a function of the natural $\log$ of titanomagnetite-melt partition coefficient of $\mathrm{Mg}$ for And-190, And-
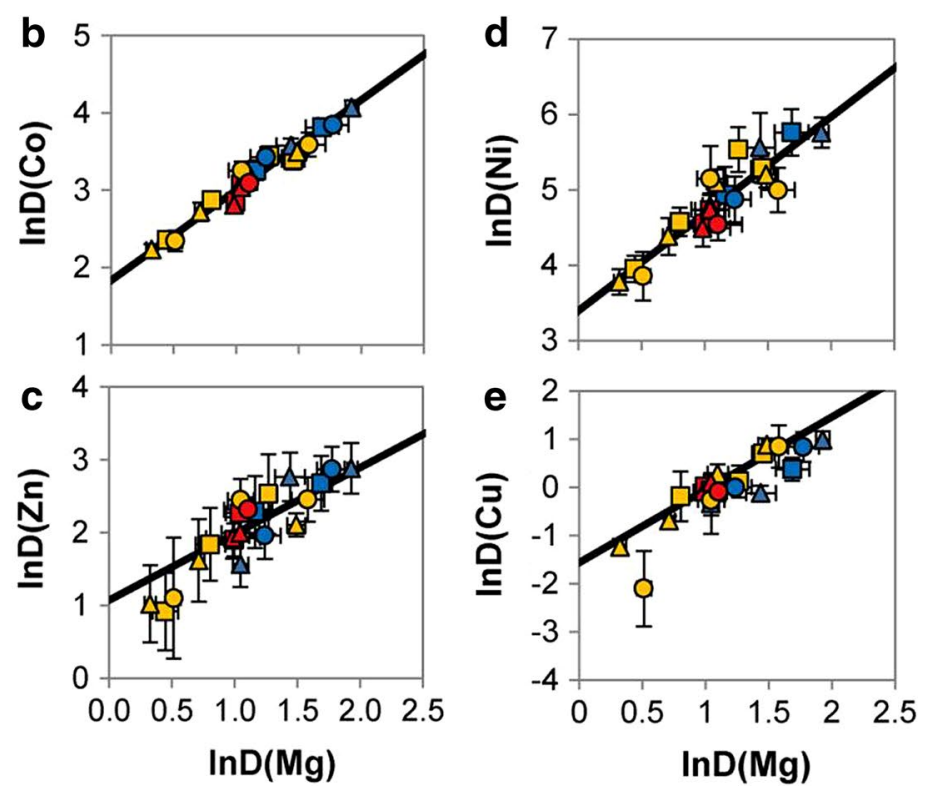

$190+\mathrm{Fe}_{2} \mathrm{O}_{3}$, And-190 $+\mathrm{Fe}_{2} \mathrm{O}_{3}+$ trace and JA- $1+\mathrm{Fe}_{2} \mathrm{O}_{3}$ starting compositions. Lines are non-linear least-squared regression and their respective values of $a_{\mathrm{M}}^{0}$ and $a_{\mathrm{M}}^{1}$ are given in Table 5. Error bars $=1 \sigma$ 

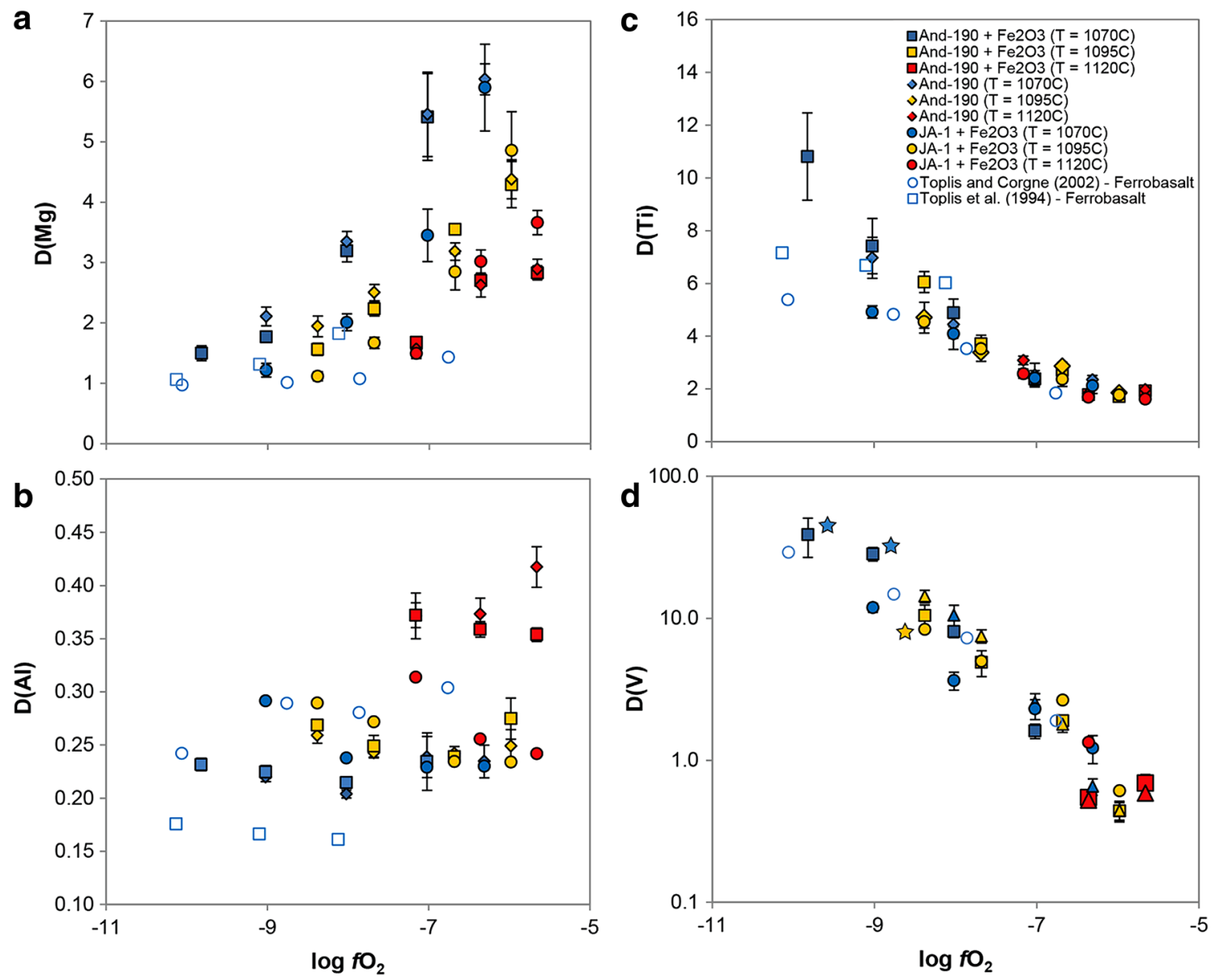

Fig. 5 Titanomagnetite-melt partition coefficients of a $\mathrm{Mg}, \mathbf{b} \mathrm{Al}, \mathbf{c}$ $\mathrm{Ti}$ and $\mathbf{d} \mathrm{V}$ as a function of $\log f \mathrm{O}_{2}$. All partition coefficients for $\mathrm{Mg}$, $\mathrm{Al}$ and $\mathrm{Ti}$ were determined using EPMA data; $D(\mathrm{~V})$ values determined using LA-ICP-MS data apart from those denoted with a star

to $\mathrm{Nb}$ at higher temperature, with $D(\mathrm{Nb}) / D(\mathrm{Ta})$ decreasing from $0.82-0.85$ at $1070{ }^{\circ} \mathrm{C}$ to $0.57-0.65$ at $1120{ }^{\circ} \mathrm{C}$ in the And-190 $+\mathrm{Fe}_{2} \mathrm{O}_{3}+$ trace starting material. There is no significant variation in $D(\mathrm{Nb}) / \mathrm{D}(\mathrm{Ta})$ with variation in $f \mathrm{O}_{2}$. The results for the relative partition coefficients for the HFSEs contrast with earlier studies investigating spinel-melt partitioning in a more mafic bulk system $\left(\mathrm{SiO}_{2}<50 \mathrm{wt} \%\right)$, which found these to be uniform (Nielsen et al. 1994; Horn et al. 1994). This study, however, covers a relatively narrow range in spinel composition, with $\mathrm{Fe}^{3+} /\left(\mathrm{Fe}^{3+}+\mathrm{Al}^{3+}+\mathrm{Cr}^{3+}+(2\right.$ $* \mathrm{Ti}^{4+}$ ) cpfu between 0.59 and 0.89 .

Nielsen and Beard (2000) observed that the spinel composition, notably $\mathrm{Al}$ content, correlates with the partition coefficients for some elements. This is to be expected where the range of spinel compositions is large, due to the dependence of the activities of components in spinel with composition (e.g. O'Neill and Navrotsky 1984). However, the thermodynamic model of O'Neill and Navrotsky (1984) suggests that this factor will be of minor importance over where $\mathrm{V}$ content was measured with EPMA due to small crystal size. Relevant literature data are included for comparison (Toplis et al. 1994; Toplis and Corgne 2002). Error bars $=1 \sigma$

the limited compositional range of $\mathrm{Fe}_{3} \mathrm{O}_{4}$-rich spinels in this study; instead, empirical correlations with a factor such as $\mathrm{Al}$ in spinel can be explained by the response of $\mathrm{Al}$ partitioning to the same thermodynamic effects of melt composition, particularly $\mathrm{Fe}^{2+} \mathrm{O}_{\text {melt }}$, as other cations (see below).

Molybdenum was only present in titanomagnetite above the detection limit using LA-ICP-MS at $\mathrm{fO}_{2}<\mathrm{FMQ}+3.7$ at $1070{ }^{\circ} \mathrm{C}$, and $f \mathrm{O}_{2}<\mathrm{FMQ}+3$ at $1095{ }^{\circ} \mathrm{C}$. Despite the lack of data, it is clear that there is a decrease in $D(\mathrm{Mo})$ with increasing $f \mathrm{O}_{2}$ and increasing temperature. In experiments using And-190 $+\mathrm{Fe}_{2} \mathrm{O}_{3}+$ trace elements, at $1095{ }^{\circ} \mathrm{C}$, $D$ (Mo) decreases from $0.103 \pm 0.016$ to $0.029 \pm 0.008$ between FMQ $+1.3 \leq f \mathrm{O}_{2} \leq \mathrm{FMQ}+2$, and at $1070{ }^{\circ} \mathrm{C}$, $D$ (Mo) decreases from $0.046 \pm 0.012$ to $0.011 \pm 0.005$ between FMQ $+2 \leq f \mathrm{O}_{2} \leq \mathrm{FMQ}+3$. This trend of decreasing $D(\mathrm{Mo})$ with increasing $f \mathrm{O}_{2}$ was previously reported for spinel by Wijbrans et al. (2015) in a synthetic ultramafic bulk system, although $D(\mathrm{Mo})$ was significantly lower in their experiments $(\mathrm{D}(\mathrm{Mo})=0.0028$ at 


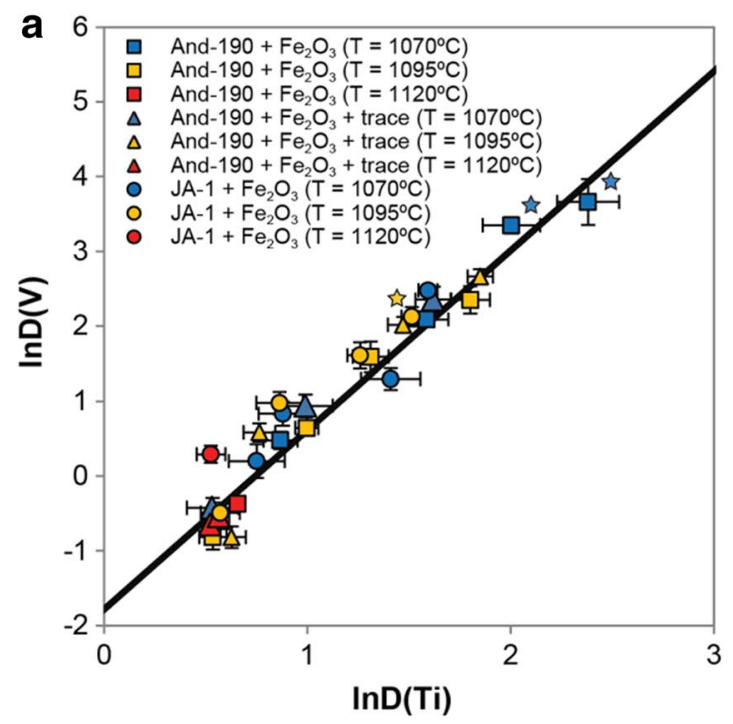

Fig. 6 Natural $\log$ of titanomagnetite-melt partition coefficients of a $\mathrm{V}, \mathbf{b} \mathrm{Zr}$ and $\mathbf{c} \mathrm{Hf}$ as a function of $\ln D(\mathrm{Ti})$, and $\mathbf{d} \ln D(\mathrm{Nb})$ and e $\ln D(\mathrm{Ta})$ as a function of $\ln D(\mathrm{Ti})-\left(1 / 12 \times \ln f \mathrm{O}_{2}\right)-(1 / 3 \times$ ln $X \mathrm{Fe}^{3+} \mathrm{O}_{1.5}$ ). Ti concentrations determined using EPMA; all other concentrations determined using LA-ICP-MS apart from three points

$\left.T=1220{ }^{\circ} \mathrm{C}, f \mathrm{O}_{2}=\mathrm{FMQ}+2.1\right)$. The decrease in $D(\mathrm{Mo})$ with increasing $f \mathrm{O}_{2}$ could be explained by a change in valence state from $\mathrm{Mo}^{4+}$ to $\mathrm{Mo}^{6+}$, suggesting that the tetravalent phase is more compatible. Nonetheless, like the other polyvalent elements such as $\mathrm{Cu}$ and $\mathrm{V}, \mathrm{Mo}^{4+}, \mathrm{Mo}^{5+}$ and $\mathrm{Mo}^{6+}$ could all be accommodated independent of $f \mathrm{O}_{2}$ at high temperature via coupled exchange with $\mathrm{Fe}^{2+}$ and $\mathrm{Fe}^{3+}$.

\section{Discussion}

\section{Prevailing valence states of elements in the melt}

The oxidation states of a number of the trace elements studied namely, $\mathrm{Fe}, \mathrm{Cu}$, Mo and $\mathrm{V}$, are redox-variable under natural conditions on earth. Copper can occur as both $\mathrm{Cu}^{+}$ and $\mathrm{Cu}^{2+}$, but is predominantly $\mathrm{Cu}^{+}$in the melt over the experimental conditions studied here, as suggested by the previous spinel-melt partitioning experiments by Liu et al. $(2014,2015)$ and the metal solubility study of Ripley and Brophy (1995). Molybdenum exists as $4+$ and $6+$ in silicate melts, but is likely to be $\mathrm{Mo}^{6+}$ in the melts studied here (O'Neill and Eggins 2002). Moreover, although $\mathrm{Ti}^{3+}$ could occur at reduced conditions $\left(f \mathrm{O}_{2}<\mathrm{FMQ}-2\right)$, Ti is expected to be present as $\mathrm{Ti}^{4+}$ in the melt in these experiments (Mallmann and O'Neill 2009). Finally, V can occur in multiple valence states in silicate melts, but is likely to occur as $\mathrm{V}^{3+}, \mathrm{V}^{4+}$ and $\mathrm{V}^{5+}$ in the melt studied here (Toplis and Corgne 2002; Mallmann and O'Neill 2009). labelled with a star, where V content was measured with EPMA due to small crystal size. Lines are non-linear least-squared regression and their respective values of $a_{\mathrm{M}}^{0}$ and $a_{\mathrm{M}}^{1}$ are given in Table 5. Error bars $=1 \sigma$

\section{Factors controlling titanomagnetite-melt partitioning}

\section{Thermodynamic explanation of element partitioning}

Thermodynamic principles show that an essential feature of any mineral-melt partitioning is the "stoichiometric control" described by the appropriate equilibrium reaction. Such reactions in general depend on the valence state of the partitioning element, the valence state of the element for which the partitioning element substitutes, hence the charge-balance mechanism, and the crystallographic site or sites on which the substitution takes place (e.g. O'Neill and Eggins 2002). In the case of magnetite, with its nearrandom distribution of $\mathrm{Fe}^{2+}$ and $\mathrm{Fe}^{3+}$ over the two distinct cation sites, the details of site occupancy are less important than usual, but the stoichiometric control remains critical. In the case of polyvalent trace elements (e.g. $\mathrm{Cu}, \mathrm{V}$ and Mo) in magnetite, there is also the additional complexity in the thermodynamics from the charge-transfer process.

\section{Partitioning of divalent cations}

The partitioning of divalent cations, such as $\mathrm{Mg}, \mathrm{Mn}, \mathrm{Co}$, $\mathrm{Ni}$ and $\mathrm{Zn}$, into magnetite can be described by the reaction:

$$
\mathrm{M}^{2+} \mathrm{O}_{\text {melt }}+\mathrm{Fe}^{2+} \mathrm{Fe}^{3+}{ }_{2} \mathrm{O}_{4 \text { spinel }} \rightleftharpoons \mathrm{M}^{2+} \mathrm{Fe}_{2}^{3+} \mathrm{O}_{4 \text { spinel }}+\mathrm{Fe}^{2+} \mathrm{O}_{\text {melt }} \text {, }
$$

for which the equilibrium constant, $\mathrm{K}$, is: 
$\mathrm{K}=\frac{\left(a \mathrm{M}^{2+} \mathrm{Fe}_{2}^{3+} \mathrm{O}_{4 \mathrm{mgt}}\right) \times\left(a \mathrm{Fe}^{2+} \mathrm{O}_{\text {melt }}\right)}{\left(a \mathrm{Fe}^{2+} \mathrm{Fe}_{2}^{3+} \mathrm{O}_{4 \mathrm{mgt}}\right) \times\left(a \mathrm{M}^{2+} \mathrm{O}_{\text {melt }}\right)}$.

By relating activities to the product of concentrations times activity coefficients in the usual way, and converting from mole fractions to concentrations by weight where appropriate, Eq. 2 can be rewritten as:

$\mathrm{K}_{\mathrm{M}}^{*}=\frac{\left[\mathrm{M}^{2+}\right]_{\mathrm{mgt}}}{\left[\mathrm{M}^{2+}\right]_{\mathrm{melt}}} \times \frac{\gamma \mathrm{M}_{\mathrm{mgt}}^{2+}}{\mathrm{aFe}_{3} \mathrm{O}_{4 \mathrm{mgt}}} \times X \mathrm{Fe}^{2+} \mathrm{O}_{\text {melt }} \times \frac{\gamma \mathrm{Fe}^{2+} \mathrm{O}_{\text {melt }}}{\gamma \mathrm{M}^{2+} \mathrm{O}_{\text {melt }}}$,

where $\mathrm{rM}^{2+} \mathrm{O}_{\text {melt }}$ and $\mathrm{rFe}^{2+} \mathrm{O}_{\text {melt }}$ are the activity coefficients of the components $\mathrm{M}^{2+} \mathrm{O}$ and $\mathrm{Fe}^{2+} \mathrm{O}$ in the melt, and $\gamma \mathrm{M}_{\mathrm{mgt}}^{2+}$ is the activity coefficient of the $\mathrm{M}^{2+} \mathrm{Fe}_{2}^{3+} \mathrm{O}_{4}$ component in the magnetite solid solution, which may, in principle, change with the major-element composition of the magnetite where this differs from pure $\mathrm{Fe}_{3} \mathrm{O}_{4}$ (in this study, mainly solid solution towards $\mathrm{Fe}_{2} \mathrm{TiO}_{4}$ ). The weight ratio $\left[\mathrm{M}^{2+}\right]_{\mathrm{mgt}} /\left[\mathrm{M}^{2+}\right]_{\text {melt }}$ is the partition coefficient $D\left(\mathrm{M}^{2+}\right)$, and $\mathrm{K}^{*}$ is the equilibrium constant using a mix of concentrations-by-weights and mole fractions.

Rearranging gives:

$\mathrm{D}\left(\mathrm{M}^{2+}\right)=\mathrm{K}_{\mathrm{M}}^{*} \times \frac{\mathrm{aFe}_{3} \mathrm{O}_{4 \mathrm{mgt}}}{\gamma \mathrm{M}_{\mathrm{mgt}}^{2+}} \times \frac{1}{\mathrm{XFe}^{2+} \mathrm{O}_{\text {melt }}} \times \frac{\gamma \mathrm{M}^{2+} \mathrm{O}_{\text {melt }}}{\gamma \mathrm{Fe}^{2+} \mathrm{O}_{\text {melt }}}$,

which shows that the magnetite-melt partition coefficients of divalent cations are strongly dependent on $\mathrm{XFe}^{2+} \mathrm{O}$, which is related to $f \mathrm{O}_{2}$ by the reaction $\mathrm{Fe}^{2+} \mathrm{O}+1 / 4$ $\mathrm{O}_{2}=\mathrm{Fe}^{3+} \mathrm{O}_{1.5}$. We may use Eq. 3 for comparing the partitioning behaviour of elements with $2+$ cations independently of variations in the activity of magnetite $\left(a \mathrm{Fe}_{3} \mathrm{O}_{4 \mathrm{mgt}}\right)$ by selecting one of the divalent cations as a reference. We chose $\mathrm{Mg}$ for this role, because it is in sufficient concentration in all experiments to be analysed precisely by EPMA, even in smaller magnetite crystals. By dividing Eq. 4 for $\mathrm{Mg}$ from Eq. 4 for another divalent cation, M, we obtain:

$\mathrm{D}\left(\mathrm{M}^{2+}\right)=\mathrm{D}(\mathrm{Mg}) \times \frac{\mathrm{K}_{\mathrm{M}}^{*}}{\mathrm{~K}_{\mathrm{Mg}}^{*}} \times \frac{\gamma \mathrm{M}^{2+} \mathrm{O}_{\text {melt }}}{\gamma \mathrm{Mg}^{2+} \mathrm{O}_{\text {melt }}} \times \frac{\gamma \mathrm{Mg}_{\mathrm{mgt}}}{\gamma \mathrm{M}_{\mathrm{mgt}}^{2+}}$.

Hence plots of $\ln D\left(\mathrm{M}^{2+}\right)$ vs. $\ln D(\mathrm{Mg})$ at a given temperature and pressure should produce straight lines with a slope of unity and an intercept of $\frac{\mathrm{K}_{\mathrm{M}}^{*}}{\mathrm{~K}_{\mathrm{Mg}}^{*}} \times \frac{\gamma \mathrm{M}^{2+} \mathrm{O}_{\text {melt }}}{\gamma \mathrm{Mg}^{2+} \mathrm{O}_{\text {melt }}} \times \frac{\gamma \mathrm{Mg}_{\mathrm{mgt}}}{\gamma \mathrm{M}_{\mathrm{mgt}}^{2+}}$, regardless of $a \mathrm{Fe}_{3} \mathrm{O}_{4}$ (magnetite composition), provided that both the ratios of activity coefficients, namely $\frac{\gamma \mathrm{Mg}_{\mathrm{mgt}}}{\gamma \mathrm{M}_{\mathrm{mgt}}^{2+}}$ and $\frac{\gamma \mathrm{M}^{2+} \mathrm{O}_{\text {melt }}}{\gamma \mathrm{Mg}^{2+} \mathrm{O}_{\text {melt }}}$ are constant. For the melt, there is a considerable body of experimental evidence addressing this question. The activity coefficients for the divalent cations $\left(\mathrm{Mg}^{2+}, \mathrm{Co}^{2+}, \mathrm{Ni}^{2+}, \mathrm{Fe}^{2+}\right)$ have been investigated experimentally over a wide range of melt compositions (O'Neill and Eggins 2002; O'Neill and Berry 2006; Toplis 2005; Doyle and Naldrett 1987), and those of $\mathrm{Mn}^{2+}$ and $\mathrm{Zn}^{2+}$ have also been studied, albeit over a more limited range (Kohn and Schofield 1994). The absolute variation in individual activity coefficients is only within a factor of two over a wide range of melt compositions, and although they do not correlate with any simple parameter such as melt chemistry or melt structural descriptor (O'Neill and Eggins 2002), their ratios (e.g. $\gamma \mathrm{Mg}^{2+} / \gamma \mathrm{Fe}^{2+}$ ) remain almost constant, only exhibiting small dependences on silica content and concentration of alkalis (Toplis 2005; O'Neill and Berry 2006). Similarly, the systematics of thermodynamic mixing properties in complex spinel solid solutions indicate that the ratio $\frac{\gamma \mathrm{Mg}_{\mathrm{mgt}}}{\gamma \mathrm{M}_{\mathrm{mgt}}^{2+}}$ is likely to remain approximately constant within the rather limited range of spinel compositions covered by the $\mathrm{Fe}_{3} \mathrm{O}_{4}$-rich spinels of this study (or similar studies on "magnetite", because such systematics depend mainly on two fundamental properties of the cations themselves, their site preference energies and ionic radii (O'Neill and Navrotsky 1984). The temperature range of this study $\left(1070-1120^{\circ} \mathrm{C}\right)$ is sufficiently small that the change of $\mathrm{K}_{\mathrm{M}}{ }^{*}$ with temperature may be ignored as a first approximation. Nevertheless, Nielsen et al. (1994) have shown that spinel composition also correlates with mineral-melt partitioning of some trace elements. Therefore, it is important to emphasise that this model may not be applicable to magnetite-poor spinel crystallised in bulk compositions which contrast with the andesitic-dacitic system studied here.

Plots of $\ln D\left(\mathrm{M}^{2+}\right)$ vs. $\ln D(\mathrm{Mg})$ are shown in Fig. 4, where $\mathrm{M}=\mathrm{Mn}, \mathrm{Co}, \mathrm{Ni}$ and $\mathrm{Zn}$. These data were fit by a global nonlinear least-squares model to minimise Chi-square:

$$
\begin{aligned}
x^{2}= & \sum_{\mathrm{M}}\left(\frac{\ln D(\mathrm{M})_{\mathrm{obs}}-a_{\mathrm{M}}^{0}-a_{\mathrm{M}}^{1} \ln D(\mathrm{Mg})_{\mathrm{calc}}}{s(\ln D(\mathrm{M}))}\right)^{2} \\
& +\left(\frac{\ln D(\mathrm{Mg})_{\mathrm{obs}}-\ln D(\mathrm{Mg})_{\mathrm{calc}}}{s(\ln D(\mathrm{M}))}\right)^{2}
\end{aligned}
$$

where $\mathrm{M}=\mathrm{Mn}, \mathrm{Co}, \mathrm{Ni}, \mathrm{Zn}$ and also $\mathrm{Cu}$, as discussed below, with uncertainties from Table 3. The results are summarised in Table 5. If the approximations just discussed are valid, the values of $a_{\mathrm{M}}^{1}$ should be 1 . For Mn, Co and $\mathrm{Zn}, a_{\mathrm{M}}^{1}$ is close to 1 with values $0.97,1.16$ and 0.91 , respectively. The value of $a_{\mathrm{Ni}}^{1}$ is somewhat higher (1.29). It is clear that the influence of melt composition, other than the all-important $\mathrm{Fe}^{2+} \mathrm{O}_{\text {melt }}$ (Eq. 4), is a rather minor input in the nearly order-of-magnitude 
variations in the partition coefficients of the divalent cations seen in this study.

\section{Partitioning of $\mathrm{Cu}$}

Empirically, $D(\mathrm{Cu})$ correlates quite well with $D(\mathrm{Mg})$ as shown in Fig. 4, but the slope of $\ln D(\mathrm{Cu})$ vs. $\ln D(\mathrm{Mg})$ at 1.51 (Table 5) is noticeably larger than unity. The valence state of $\mathrm{Cu}$ in silicate melts under the $f_{2}$ regime of this study is predominantly $1+$ (Ripley and Brophy 1995; Liu et al. 2014, 2015). One distinctive crystal-chemical feature of magnetite trace-element partitioning compared to most other minerals is that in the magnetite, but not the melt, the valence states of redox-variable elements reflect the stoichiometry of magnetite through electronexchange reactions. Thus, the valence state of redox-variable elements in stoichiometric magnetite is independent of $f \mathrm{O}_{2}$. For $\mathrm{Cu}$, the electron-exchange could be written:

$\mathrm{Cu}^{1+}+\mathrm{Fe}^{3+}=\mathrm{Fe}^{2+}+\mathrm{Cu}^{2+}$,

(e.g. O'Neill and Navrotsky 1983, 1984).

The appropriate thermodynamic component is the fully oxidised end-member $\mathrm{Cu}^{2+} \mathrm{Fe}_{2}^{3+} \mathrm{O}_{4}$, a well-known ferrite spinel (Nickel 1973). The reasons for selecting this component rather than say $\mathrm{Cu}_{0.5}^{1+} \mathrm{Fe}_{2.5}^{3+} \mathrm{O}_{4}$ (by analogy with $\mathrm{Li}_{0.5}^{1+} \mathrm{Fe}_{2.5}^{3+} \mathrm{O}_{4}$ ) will be discussed further below. The partitioning equilibrium is then:

$\mathrm{Cu}^{1+} \mathrm{O}_{0.5 \text { melt }}+\mathrm{Fe}_{3} \mathrm{O}_{4 \text { spinel }}+\frac{1}{4} \mathrm{O}_{2}=\mathrm{Cu}^{2+} \mathrm{Fe}_{2}^{3+} \mathrm{O}_{4 \text { spinel }}+\mathrm{Fe}^{2+} \mathrm{O}_{\text {melt }}$.

Using Eqs. 1 and 2 (the $\mathrm{Fe}^{2+} \mathrm{O}+1 / 4 \mathrm{O}_{2}=\mathrm{Fe}^{3+} \mathrm{O}_{1.5}$ and the $\mathrm{Fe}^{2+} \mathrm{O}+2 \mathrm{Fe}^{3+} \mathrm{O}_{1.5}=\mathrm{Fe}_{3} \mathrm{O}_{4}$ equilibria) to eliminate $\mathrm{O}_{2}$, the comparison with the partitioning equilibrium for $\mathrm{Mg}$ to eliminate the effect of $a \mathrm{Fe}_{3} \mathrm{O}_{4 \mathrm{mgt}}$ gives:

$$
\begin{aligned}
& \mathrm{Cu}^{1+} \mathrm{O}_{0.5 \text { melt }}+1.5 \mathrm{MgFe}_{2}^{3+} \mathrm{O}_{4 \text { spinel }}=\mathrm{Cu}^{2+} \mathrm{Fe}_{2}^{3+} \mathrm{O}_{4 \text { spinel }} \\
& +\mathrm{Fe}^{2+} \mathrm{O}_{\text {melt }}+1.5 \mathrm{MgO}_{\text {melt }} .
\end{aligned}
$$

Hence:

$$
\begin{aligned}
D(\mathrm{Cu})= & 1.5 \ln D(\mathrm{Mg})-\ln X \mathrm{Fe}^{2+} \mathrm{O}_{\text {melt }}-\ln K(*) \\
& +\ln \frac{\gamma \mathrm{Mg}_{\mathrm{mgt}}}{\gamma \mathrm{Cu}_{\mathrm{mgt}}^{2+}}-\ln \frac{\gamma \mathrm{Fe}^{2+} \mathrm{O}_{\text {melt }}\left(\gamma \mathrm{MgO}_{\text {melt }}\right)^{1.5}}{\gamma \mathrm{Cu}^{1+} \mathrm{O}_{0.5 \text { melt }}} .
\end{aligned}
$$

Although we do find the slope of $\ln D(\mathrm{Cu})$ versus $\ln D(\mathrm{Mg})$ is near 1.5 (Fig. 4e), this appears to be coincidental. If the expected effect of $X \mathrm{Fe}^{2+} \mathrm{O}_{\text {melt }}$ is factored in, the relationship disappears: a plot of $\ln D(\mathrm{Cu})$ vs. $\left\{\ln D(\mathrm{Mg})-\ln X \mathrm{Fe}^{2+} \mathrm{O}_{\text {melt }}\right\}$ gives a slope of 0.68 ; the discrepancy with theory presumably reflects a substantial change of the quotient of activity coefficients in the melt, $\frac{\gamma \mathrm{Fe}^{2+} \mathrm{O}_{\text {melt }}\left(\gamma \mathrm{MgO}_{\text {melt }}\right)^{1.5}}{\gamma \mathrm{Cu}^{1+} \mathrm{O}_{0.5 \text { melt }}}$, with melt composition.

The reasons for selecting $\mathrm{CuFe}_{2} \mathrm{O}_{4}$ rather than $\mathrm{Cu}_{0.5} \mathrm{Fe}_{2.5} \mathrm{O}_{4}$ as the $\mathrm{Cu}$-containing component in magnetite start with the observation that the phase relations in the system $\mathrm{Cu}-\mathrm{Fe}-\mathrm{O}$ show a continuous solid solution, with a smooth change of free energy along the binary join running from the spinel composition stable at the most oxidising conditions achievable in this system, which is $\mathrm{Cu}^{2+} \mathrm{Fe}_{2}^{3+} \mathrm{O}_{4}$, to that stable at the most reduced extreme, which is $\mathrm{Fe}_{3} \mathrm{O}_{4}$ (Jacob et al. 1977; Katayama et al. 1980; Katkov and Lykasov 2003). The composition $\mathrm{CuFe}_{2.5} \mathrm{O}_{4}$ is simply the 50:50 composition. Its cationic configuration could in principle be anywhere between $\mathrm{Cu}_{0.5}^{1+} \mathrm{Fe}_{2.5}^{3+} \mathrm{O}_{4}$ (all $\mathrm{Cu}$ as $1^{+}$, no $\mathrm{Fe}^{2+}$ ) or $\mathrm{Cu}_{0.5}^{2+} \mathrm{Fe}_{0.5}^{2+} \mathrm{Fe}_{2}^{3+} \mathrm{O}_{4}$ (all $\mathrm{Cu}$ as $2+)$; these possibilities are related by the homogeneous equilibrium $\quad \mathrm{Cu}^{2+} \mathrm{Fe}_{2}^{3+} \mathrm{O}_{4}+\mathrm{Fe}_{3} \mathrm{O}_{4}=2 \mathrm{Cu}_{0.5}^{1+} \mathrm{Fe}_{2.5}^{3+} \mathrm{O}_{4}$. Alternatively, this equilibrium could be expressed as the electron-exchange reaction $\mathrm{Cu}^{2+}+\mathrm{Fe}^{2+}=\mathrm{Cu}^{1+}+\mathrm{Fe}^{3+}$, as noted above. This electron-exchange reaction results in a large negative deviation from ideal mixing in the binary join $\mathrm{Cu}^{2+} \mathrm{Fe}_{2}^{3+} \mathrm{O}_{4}-\mathrm{Fe}_{3} \mathrm{O}_{4}$, due to the extra configurational entropy that it confers. Note that while the ratio of $\mathrm{Cu}^{1+} / \mathrm{Cu}^{2+}$ in the spinel at a given $\mathrm{Cu} / \mathrm{Fe}$ is expected to depend on temperature, it is independent of $f_{2}$, being controlled, through the electron-exchange reaction, by the stoichiometry of the spinel. Although the thermodynamic properties of a component with stoichiometry $\mathrm{Cu}_{0.5} \mathrm{Fe}_{2.5} \mathrm{O}_{4}$ could in principle be derived from the experimentally determined phase relations, they would depend on those of $\mathrm{CuFe}_{2} \mathrm{O}_{4}$ anyway. It is therefore simpler to stick with the latter.

\section{Partitioning of trivalent cations}

The partitioning of trivalent cations, such as $\mathrm{Sc}^{3+}$, into magnetite can be described as follows:

$\mathrm{M}^{3+} \mathrm{O}_{1.5 \mathrm{melt}}+{ }^{1} / 2 \mathrm{Fe}^{2+} \mathrm{Fe}^{3+}{ }_{2} \mathrm{O}_{4} \rightleftharpoons 1 / 2 \mathrm{Fe}^{2+} \mathrm{M}^{3+}{ }_{2} \mathrm{O}_{4}+\mathrm{FeO}_{1.5 \text { melt }}$

Based on similar thermodynamic assumptions as for the partitioning of divalent cations, the partitioning of trivalent cations between magnetite and melt would be expected to follow the expression:

$$
\begin{aligned}
D_{M^{3+}(\mathrm{mgt}-\mathrm{melt})}= & \mathrm{K}_{\mathrm{M}}^{*} \times \frac{\left(a \mathrm{Fe}^{2+} \mathrm{Fe}_{2}^{3+} \mathrm{O}_{4 \mathrm{mgt}}\right)^{\frac{1}{2}}}{\gamma \mathrm{M}_{\mathrm{mgt}}^{3+}} \\
& \times \frac{1}{X \mathrm{Fe}^{3+} \mathrm{O}_{1.5 \mathrm{melt}}} \times \frac{\gamma \mathrm{M}^{3+} \mathrm{O}_{1.5 \mathrm{melt}}}{\gamma \mathrm{Fe}^{3+} \mathrm{O}_{1.5 \mathrm{melt}}}
\end{aligned}
$$


Table 5 Values of $a_{\mathrm{M}}^{0}$ and $a_{\mathrm{M}}^{1}$ from fitting titanomagnetitemelt partitioning for elements (M) to global non-linear leastsquares model to minimise Chisquare using the partitioning of another cation as a reference using data from this study (see Eq. 8)

\begin{tabular}{lcrc}
\hline Reference & $\ln D(\mathrm{M})$ & $a_{\mathrm{M}}^{0}$ & $a_{\mathrm{M}}^{1}$ \\
\hline $\ln D(\mathrm{Mg})$ & $\ln D(\mathrm{Mn})$ & 0.29 & 0.97 \\
$\ln D(\mathrm{Mg})$ & $\ln D(\mathrm{Co})$ & 1.82 & 1.17 \\
$\ln D(\mathrm{Mg})$ & $\ln D(\mathrm{Ni})$ & 3.39 & 1.29 \\
$\ln D(\mathrm{Mg})$ & $\ln D(\mathrm{Zn})$ & 1.07 & 0.91 \\
$\ln D(\mathrm{Mg})$ & $\ln D(\mathrm{Cu})$ & -1.56 & 1.51 \\
$\ln D(\mathrm{Mg})-\ln X \mathrm{Fe}^{2+} \mathrm{O}($ melt $)$ & $\ln D(\mathrm{Cu})$ & -3.69 & 0.68 \\
$\ln D(\mathrm{Ti})$ & $\ln D(\mathrm{~V})$ & -1.79 & 2.40 \\
$\ln D(\mathrm{Ti})$ & $\ln D(\mathrm{Zr})$ & -3.62 & 0.80 \\
$\ln D(\mathrm{Ti})$ & $\ln D(\mathrm{Hf})$ & -3.19 & 0.75 \\
$\ln D(\mathrm{Ti})$ & $\ln D(\mathrm{Nb})$ & -4.28 & 1.40 \\
$\ln D(\mathrm{Ti})$ & $\ln D(\mathrm{Ta})$ & -3.73 & 1.25 \\
$\ln D(\mathrm{Ti})-\left((1 / 12) * \ln f \mathrm{O}_{2}\right)-\left(1 / 3 * \ln X \mathrm{Fe}^{3+} \mathrm{O}_{1.5}(\mathrm{melt})\right)$ & $\ln D(\mathrm{Nb})$ & -6.61 & 1.01 \\
$\ln D(\mathrm{Ti})-\left((1 / 12) * \ln f \mathrm{O}_{2}\right)-\left(1 / 3 * \ln X \mathrm{Fe}^{3+} \mathrm{O}_{1.5}(\mathrm{melt})\right)$ & $\ln D(\mathrm{Ta})$ & -5.94 & 0.94 \\
\hline
\end{tabular}

Similar to the analyses of partitioning of divalent cations, the partitioning behaviour of $3+$ cations can be compared to other trivalent cations as a reference. By dividing Eq. 14 for $\mathrm{Al}$ from Eq. 14 for another trivalent cation, $\mathrm{M}$, we obtain the expression:

$D\left(\mathrm{M}^{3+}\right)=D(\mathrm{Al}) \times \frac{\mathrm{K}_{\mathrm{M}}^{*}}{\mathrm{~K}_{\mathrm{Al}}^{*}} \times \frac{\gamma \mathrm{M}^{3+} \mathrm{O}_{1.5 \mathrm{melt}}}{\gamma \mathrm{Al}^{3+} \mathrm{O}_{1.5 \mathrm{melt}}} \times \frac{\gamma \mathrm{Al}_{\mathrm{mgt}}}{\gamma \mathrm{M}_{\mathrm{mgt}}^{3+}}$.

Unlike the divalent cations, plots of $\ln D(\mathrm{Sc})$ and $\ln$ $D(\mathrm{Ga})$ vs. In $D(\mathrm{Al})$ do not produce clear trends (Fig. 7). In comparison to the divalent cations, there is not a large variation in the partitioning of trivalent cations in our dataset. It could be that the partitioning of the trivalent cations is more strongly controlled by spinel composition as a result of non-ideal mixing of $\mathrm{Al}, \mathrm{Fe}^{3+}$ and $\mathrm{Cr}$ (Nielsen et al. 1994). This could explain the weak negative correlation between $\ln D(\mathrm{Sc})$ and $\ln D(\mathrm{Al})$. Alternatively, because $\mathrm{Al}$ is a major structural component of the melt, it is likely that the activity coefficients in the melt, $\frac{\gamma \mathrm{M}^{3+} \mathrm{O}_{1.5 \text { melt }}}{\gamma \mathrm{Al}^{3+} \mathrm{O}_{1.5 \text { melt }}}$, are not constant over the range of compositions and conditions studied here. Additionally, $\mathrm{K}_{\mathrm{M}}^{*}$ could be more sensitive to temperature for the trivalent cations than for the divalent cations.

\section{Partitioning of tetravalent cations}

The partitioning of tetravalent cations can be described by the reaction:

$\mathrm{M}^{4+} \mathrm{O}_{2 \text { melt }}+\mathrm{Fe}^{2+} \mathrm{Fe}_{2}^{3+} \mathrm{O}_{4} \mathrm{Fe}_{2}^{2+} \mathrm{M}^{4+} \mathrm{O}_{4}+\mathrm{Fe}^{3+} \mathrm{O}_{1.5 \text { melt }}+{ }^{1 / 4} \mathrm{O}_{2}$

Again based on similar thermodynamic assumptions, the partitioning of tetravalent cations would be expected to follow the expression:

$$
\begin{aligned}
D\left(\mathrm{M}^{4+}\right)= & \mathrm{K}_{\mathrm{M}}^{*} \times \frac{\left(a \mathrm{Fe}^{2+} \mathrm{Fe}^{3+} \mathrm{O}_{4 \mathrm{mgt}}\right)}{\left(\gamma \mathrm{M}_{\mathrm{mgt}}^{4+}\right) \times\left(f \mathrm{O}_{2}\right)^{\frac{1}{4}}} \\
& \times \frac{1}{\mathrm{XFe}^{3+} \mathrm{O}_{1.5 \mathrm{melt}}} \times \frac{\gamma \mathrm{M}^{4+} \mathrm{O}_{2 \text { melt }}}{\gamma \mathrm{Fe}^{3+} \mathrm{O}_{1.5 \text { melt }}} .
\end{aligned}
$$

In this case, the magnetite-melt partitioning of tetravalent cations is directly dependent on the $\mathrm{fO}_{2}$. By dividing Eq. 17 for Ti from Eq. 17 for another tetravalent cation, M, we obtain:

$D\left(M^{4+}\right)=D(T i) \times \frac{K_{M}^{*}}{K_{T i}^{*}} \times \frac{\gamma M^{4+} O_{2 m e l t}}{\gamma T i O_{2 m e l t}} \times \frac{\gamma T i_{m g t}}{\gamma M_{m g t}^{4+}}$.

Plots of $\ln D\left(\mathrm{M}^{4+}\right)$ vs. $\ln D(\mathrm{Ti})$ at a given temperature and pressure should produce straight lines with a slope of unity and an intercept of $\frac{\mathrm{K}_{\mathrm{M}}^{*}}{\mathrm{~K}_{\mathrm{Ti}}^{*}} \times \frac{\gamma \mathrm{M}^{4+} \mathrm{O}_{2 \text { melt }}}{\gamma \mathrm{TiO}_{2 \text { melt }}} \times \frac{\gamma \mathrm{Ti}_{\mathrm{mgt}}}{\gamma \mathrm{M}_{\mathrm{mgt}}^{4+}}$, provided that the ratios of activity coefficients are constant. Again, the ratio $\frac{\gamma \mathrm{Ti}_{\mathrm{mgt}}}{\gamma \mathrm{M}_{\mathrm{mg} t}^{4+}}$ is likely to remain constant within the range of spinel compositions studied. However, the activity coefficients for the tetravalent cations in the melt have not been investigated as comprehensively as for the divalent cations.

Plots of $\ln D\left(\mathrm{M}^{4+}\right)$ vs. $\ln D(\mathrm{Ti})$ are shown in Fig. 6, where $\mathrm{M}=\mathrm{Zr}$ and Hf. These data were fit by a global nonlinear least-squares model to minimise Chi-square. These results are summarised in Table 5. The values of $a_{\mathrm{Zr}}^{1}$ and $a_{\mathrm{Hf}}^{1}$ are 0.80 and 0.75 , respectively. This suggests that the ratio of the activity coefficients, $\frac{\gamma \mathrm{M}^{4+} O_{2 \text { melt }}}{\gamma \mathrm{TiO}_{2 \text { melt }}}$, also remains close to constant for the tetravalent cations. Similar to the partitioning of divalent cations, it is the $\mathrm{Fe}^{3+} \mathrm{O}_{1.5 \text { melt }}$ and $\mathrm{Fe}^{2+} \mathrm{O}_{\text {melt }}$ (which is controlled by the $\mathrm{OO}_{2}$ ) which dictates the primary 
control on the spinel-melt partitioning of tetravalent cations. A plot of $\ln D(\mathrm{~V})$ vs. $\ln D(\mathrm{Ti})$ does not have a slope close to unity (2.40), which would be expected given that the valence states of $\mathrm{V}$ in magnetite are, like those of $\mathrm{Cu}$, controlled by stoichiometry through electron-exchange reaction: $\mathrm{V}^{3+}+\mathrm{Fe}^{3+}=\mathrm{Fe}^{2+}+\mathrm{V}^{4+}$, with the thermodynamically convenient end-member being $\mathrm{Fe}^{2+} \mathrm{V}_{2}^{3+} \mathrm{O}_{4}$ (O'Neill and Navrotsky 1984). Thus, Eq. 16 does not suitably describe the partitioning of $\mathrm{V}$ into magnetite.

\section{Partitioning of pentavalent cations}

Pentavalent cations, such as niobian magnetite, have been shown to have solid solution towards the end-member $\mathrm{Fe}_{7 / 3}^{2+} \mathrm{Nb}_{2 / 3}^{5+} \mathrm{O}_{4}$ (Turnock 1966; Katayama 1987), hence the stoichiometry of the partitioning reaction is:

$$
\begin{aligned}
& 2 / 3 \mathrm{M}^{5+} \mathrm{O}_{2.5 \text { melt }}+\mathrm{Fe}^{2+} \mathrm{Fe}^{3+}{ }_{2} \mathrm{O}_{4} \rightleftharpoons \mathrm{Fe}^{2+}{ }_{7 / 3} \mathrm{M}^{5+}{ }_{2 / 3} \mathrm{O}_{4} \\
& +\mathrm{Fe}^{3+} \mathrm{O}_{1.5 \text { melt }}+1 / 3 \mathrm{O}_{2}
\end{aligned}
$$

Again, based on similar thermodynamic assumptions, the partitioning of tetravalent cations would be expected to follow the expression:

$$
\begin{aligned}
D\left(\mathrm{M}^{5+}\right)= & \mathrm{K}_{\mathrm{M}}^{*} \times \frac{\left(a \mathrm{Fe}^{2+} \mathrm{Fe}^{3+} \mathrm{O}_{4 \mathrm{mgt}}\right)}{\left(\gamma \mathrm{M}_{\mathrm{mgt}}^{5+}\right) \times\left(f \mathrm{O}_{2}\right)^{\frac{1}{3}}} \times \frac{1}{\left(X \mathrm{Fe}^{3+} \mathrm{O}_{1.5 \mathrm{melt}}\right)^{\frac{2}{3}}} \\
& \times \frac{\gamma \mathrm{M}^{5+} \mathrm{O}_{2.5 \mathrm{melt}}}{\left(\gamma \mathrm{Fe}^{3+} \mathrm{O}_{1.5 \mathrm{melt}}\right)^{\frac{2}{3}}} .
\end{aligned}
$$

By dividing Eq. 17 for Ti from Eq. 20 for another pentavalent cation, $\mathrm{M}$, we obtain:

$$
\begin{aligned}
D\left(\mathrm{M}^{5+}\right)= & D(\mathrm{Ti}) \times \frac{\mathrm{K}_{\mathrm{M}}^{*}}{\mathrm{~K}_{\mathrm{Ti}}^{*}} \times \frac{\gamma \mathrm{M}^{5+} \mathrm{O}_{2.5 \mathrm{melt}}}{\gamma \mathrm{TiO}_{2 \mathrm{melt}}} \times f \mathrm{O}_{2}^{-\frac{1}{12}} \\
& \times X \mathrm{Fe}^{3+} O_{1.5}^{-\frac{1}{3}} \times \frac{\gamma \mathrm{Ti}_{\mathrm{mgt}}}{\gamma \mathrm{M}_{\mathrm{mgt}}^{5+}} .
\end{aligned}
$$

After factoring in for the $f \mathrm{O}_{2}$ and $\mathrm{XFe}^{3+} \mathrm{O}_{1.5}$ terms, $D(\mathrm{Nb})$ and $D(\mathrm{Ta})$ correlate with $D(\mathrm{Ti})$, but with a slope of 1.01 and 0.94 , respectively, which suggest that $\frac{\mathrm{K}_{\mathrm{M}}^{*}}{\mathrm{~K}_{\mathrm{Ti}}^{*}} \times \frac{\gamma \mathrm{M}^{5+} \mathrm{O}_{2.5 \mathrm{melt}}}{\gamma \mathrm{TiO}_{2 \text { melt }}} \times \frac{\gamma \mathrm{Ti}_{\text {mgt }}}{\gamma \mathrm{M}_{\text {mgt }}^{5+}}$ remains approximately constant within the experimental conditions studied. Notwithstanding this, the partitioning of HFSE also correlates with $T$, Al content of spinel and P (Nielsen and Beard 2000); thus, the ratios of these activity coefficients may not be constant in spinel or melt outside the composition range studied here.

\section{Spinel thermodynamics and partitioning relations}

Spinel-melt partitioning can be evaluated more directly if $a \mathrm{Fe}_{3} \mathrm{O}_{4 \mathrm{mgt}}$ can be calculated. O'Neill and Wall (1987)

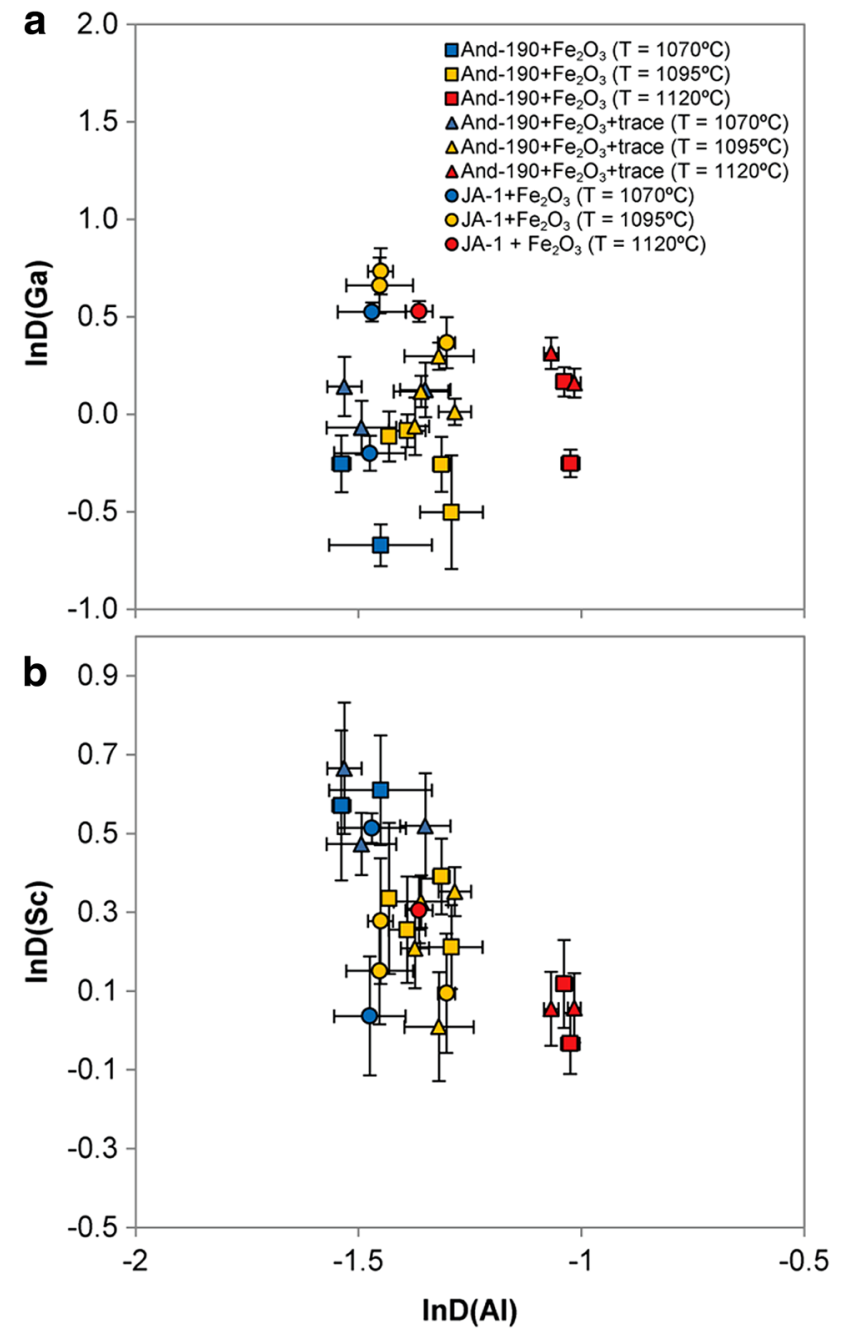

Fig. 7 Natural $\log$ of titanomagnetite-melt partition coefficients of $\mathbf{a} \mathrm{Ga}$ and $\mathbf{b} \mathrm{Sc}$ as a function of the natural $\log$ of titanomagnetite-melt partition coefficient of $\mathrm{Al}$ for And-190 $+\mathrm{Fe}_{2} \mathrm{O}_{3}$, And$190+\mathrm{Fe}_{2} \mathrm{O}_{3}+$ trace and JA-1 $+\mathrm{Fe}_{2} \mathrm{O}_{3}$ starting compositions. Error bars $=1 \sigma$

presented a model for calculating $a \mathrm{Fe}_{3} \mathrm{O}_{4 \mathrm{mgt}}$ in compositionally complex spinels in the system $\mathrm{MgO}-\mathrm{Al}_{2} \mathrm{O}_{3}-$ $\mathrm{Cr}_{2} \mathrm{O}_{3}-\mathrm{TiO}_{2}-\mathrm{Fe}-\mathrm{O}$ as a function of temperature and pressure. The $\mathrm{Fe}^{2+} \mathrm{O}$ concentration in the melt can be approximated from measured total $\mathrm{Fe}$ concentrations (i.e. $\mathrm{FeO}$ total) and $f \mathrm{O}_{2}$ using the empirical parameterisation of Kress and Carmichael (1991), which can then be converted into a mole fraction on a single-cation basis $\left(\mathrm{XFe}^{2+} \mathrm{O}\right)$, so that values of $X \mathrm{Fe}^{2+} \mathrm{O}$ and $\mathrm{XFe}^{3+} \mathrm{O}_{1.5}$ can be calculated. As discussed earlier, the ratios of the activity coefficients for the divalent cations in melt and magnetite are expected to remain almost constant. Therefore, the partitioning of divalent cations would be expected to be linearly proportional to $\left(a \mathrm{Fe}_{3} \mathrm{O}_{4}\right.$ in magnetite $) /\left(\mathrm{XFe}^{2+} \mathrm{O}\right.$ in liquid), which is observed in our data (Fig. 8a-c). 

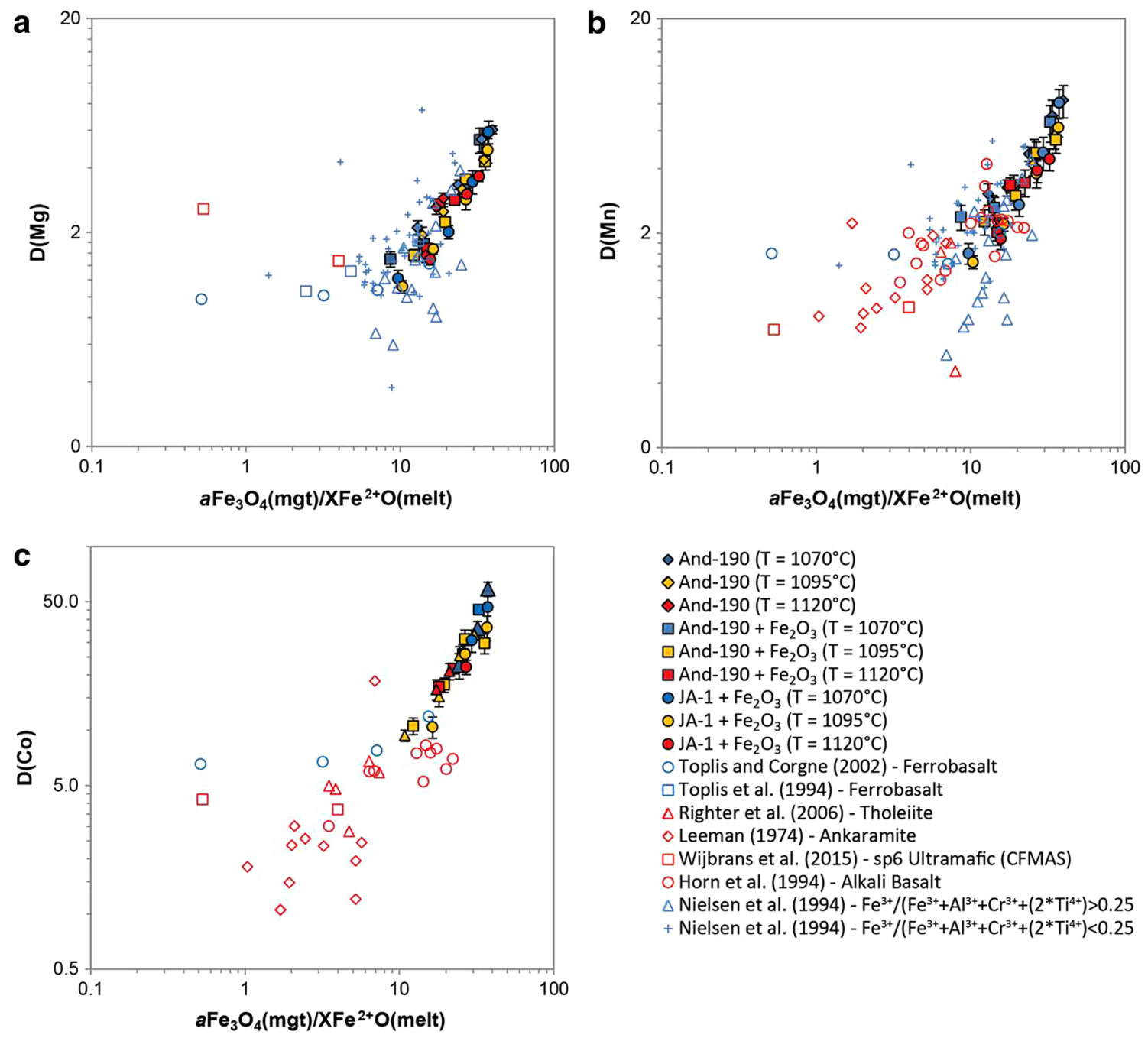

Fig. 8 Titanomagnetite-melt partition coefficients of a $\mathrm{Mg}, \mathbf{b} \mathrm{Mn}$ and c Co plotted against $a \mathrm{Fe}_{3} \mathrm{O}_{4}(\mathrm{mgt}) / \mathrm{XFe}^{2+} \mathrm{O}$ (melt). $a \mathrm{Fe}_{3} \mathrm{O}_{4}(\mathrm{mgt})$ approximated using model by O'Neill and Wall (1987), and mole fraction on single-cation basis $\mathrm{XFe}{ }^{2+} \mathrm{O}$ (melt) calculated from values approximated using Kress and Carmichael (1991). Literature data include: Toplis and Corgne (2002), Toplis et al. (1994) and Nielsen

The linear trend for $D\left(\mathrm{M}^{2+}\right)$ as a function of $a \mathrm{Fe}_{3} \mathrm{O}_{4}(\mathrm{mgt}) / \mathrm{XFe}{ }^{2+} \mathrm{O}$ (melt) is corroborated by literature data covering a variety of bulk compositions, but breaks down in some experiments, notably those conducted at lowest $f_{2}$ by Toplis and Corgne (2002) and Toplis et al. (1994). These data are for particularly Ti-rich spinel with $\mathrm{Fe}^{3+} /\left(\mathrm{Fe}^{3+}+\mathrm{Al}^{3+}+\mathrm{Cr}^{3+}+\left(2 \times \mathrm{Ti}^{4+}\right)\right)$ cpfu of $0.11-0.30$. Furthermore, data from Nielsen et al. (1994) with $\mathrm{Fe}^{3+}$ / $\left(\mathrm{Fe}^{3+}+\mathrm{Al}^{3+}+\mathrm{Cr}^{3+}+\left(2 \times \mathrm{Ti}^{4+}\right)\right)$ cpfu $>0.25$ agree well with the linear trend defined in this study, but those with $\mathrm{Fe}^{3+}$ / $\left(\mathrm{Fe}^{3+}+\mathrm{Al}^{3+}+\mathrm{Cr}^{3+}+\left(2 \times \mathrm{Ti}^{4+}\right)\right)$ cpfu $<0.25$ do not. Mg-rich spinel in experiments by Wijbrans et al. (2015) also have elevated $D(\mathrm{Mg})$ relative to those studied here. Thus, it would seem that the model in terms of thermodynamic principles

et al. (1994) which were conducted at $1068-1130{ }^{\circ} \mathrm{C}$; and Righter et al. (2006), Leeman (1974), Horn et al. (1994) and Wijbrans et al. (2015) which were conducted between 1150 and $1370{ }^{\circ} \mathrm{C}$. Data from Nielsen et al. (1994) with spinel $\mathrm{Fe}^{3+} /\left(\mathrm{Fe}^{3+}+\mathrm{Al}^{3+}+\mathrm{Cr}^{3+}+\left(2 \times \mathrm{Ti}^{4+}\right)\right.$ $>0.25$ have been distinguished from the rest of the data from this study. Error bars $=1 \sigma$

reliably explains magnetite-melt partitioning in magnetiterich spinel, but breaks down for spinel with contrasting major-element composition to those studied here. Thus, large changes in major-element composition of the bulk system can exert an additional control on spinel-melt partitioning, as expected from models of spinel solid-solution thermodynamics (O'Neill and Navrotsky 1984). However, to establish this, the other relevant factors would first need to be accounted for. One of these is the change in the activity coefficients in the melt with the composition of the system.

In comparison to the andesitic-dacitic bulk composition studied here, in mafic bulk systems (e.g. Toplis and Corgne 2002; Toplis et al. 1994; Righter et al. 2006), there is a stronger increase in the $a \mathrm{Fe}_{3} \mathrm{O}_{4}(\mathrm{mgt})$ over a 

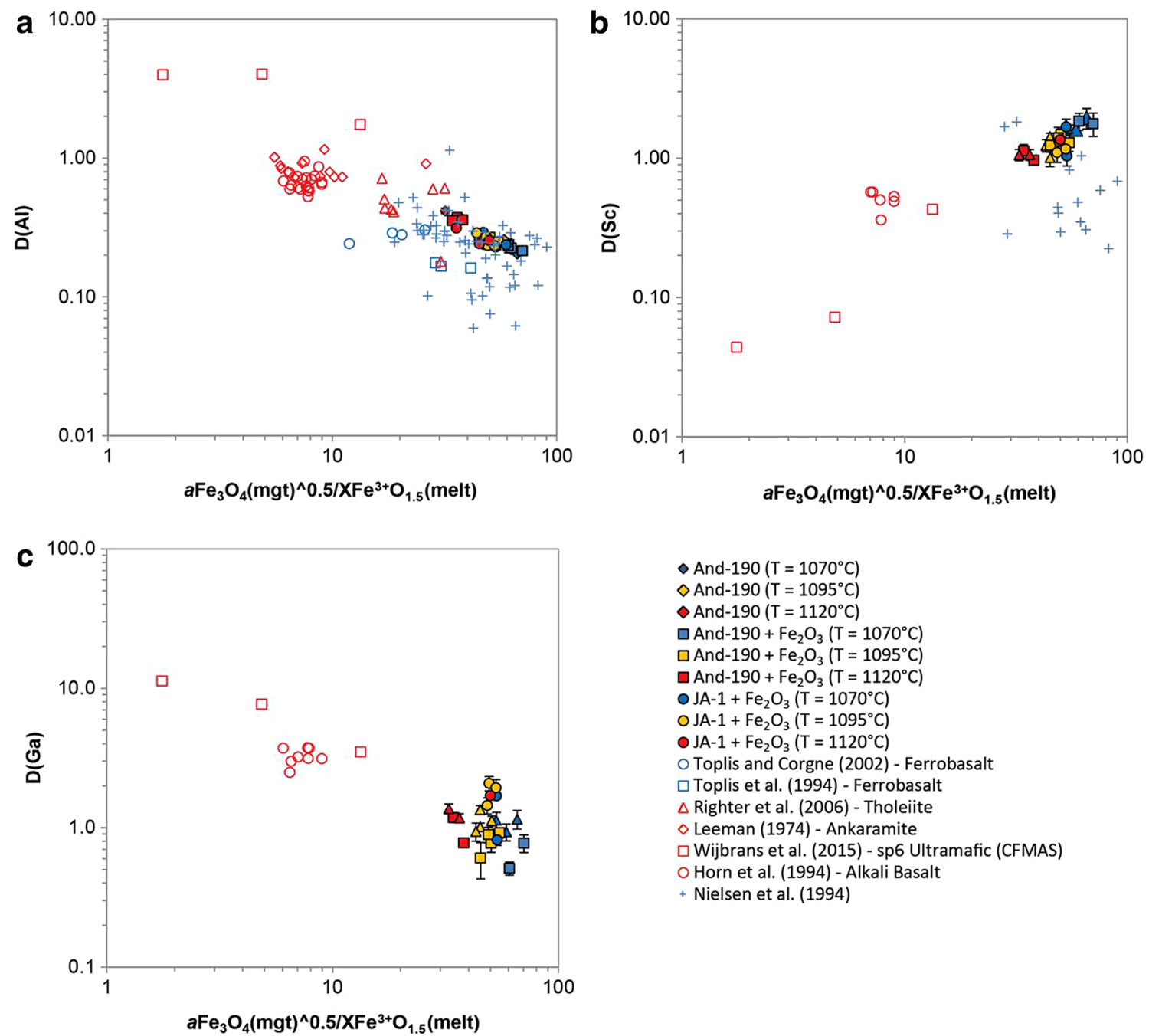

Fig. 9 Titanomagnetite-melt partition coefficients of a $D(\mathrm{Al})$ e $D(\mathrm{Sc})$ and $\mathbf{f} D(\mathrm{Ga})$ as a function of $a \mathrm{Fe}_{3} \mathrm{O}_{4}(\mathrm{mgt})^{0.5} / X \mathrm{Fe}^{3+} \mathrm{O}_{1.5}$ (melt). $a \mathrm{Fe}_{3} \mathrm{O}_{4}$ (mgt) approximated using model by O'Neill and Wall (1987), and mole fraction on single-cation basis, $\mathrm{XFe}^{3+} \mathrm{O}_{1.5}$ (melt), calculated from values approximated using Kress and Carmichael (1991). Lit-

similar range in $f \mathrm{O}_{2}$. This counteracts the decrease in $\mathrm{Fe}^{2+} \mathrm{O}$ (melt) with increasing $f \mathrm{O}_{2}$ and as a result there is significantly less variation in $a \mathrm{Fe}_{3} \mathrm{O}_{4}(\mathrm{mgt}) / \mathrm{XFe}^{2+} \mathrm{O}$ (melt) with $f \mathrm{O}_{2}$. Consequently, there is a lesser pronounced increase in $D\left(\mathrm{M}^{2+}\right)_{\text {mgt - melt }}$ with increasing $f \mathrm{O}_{2}$ in mafic bulk systems in comparison to the silicic bulk compositions studied here (Fig. 5).

There is a linear trend as a function of $a \mathrm{Fe}_{3} \mathrm{O}_{4}(\mathrm{mgt})^{0.5} / \mathrm{XFe}^{3+} \mathrm{O}_{1.5}$ (melt) for $D(\mathrm{Sc})$, which is corroborated by literature data, investigating spinel-melt partitioning in different bulk compositions (Fig. 9b). Similarly, plotting $D(\mathrm{Ga})$ vs. $a \mathrm{Fe}_{3} \mathrm{O}_{4}(\mathrm{mgt})^{0.5} / X \mathrm{Fe}^{3+}$ $\mathrm{O}_{1.5}$ (melt) generates a linear trend when combined with data using the most Fe-rich starting composition studied by Wijbrans et al. (2015); however, this trend has a

erature data include: Toplis and Corgne (2002), Toplis et al. (1994) and Nielsen et al. (1994) which were conducted at $1068-1130{ }^{\circ} \mathrm{C}$; and Righter et al. (2006), Leeman (1974), Horn et al. (1994) and Wijbrans et al. (2015) which were conducted between 1150 and $1370{ }^{\circ} \mathrm{C}$. Error bars $=1 \sigma$

negative slope (Fig. 9c). Plotting $D(\mathrm{Al})$ vs. $a \mathrm{Fe}_{3} \mathrm{O}_{4}(\mathrm{mgt})^{0.5 /}$ $X \mathrm{Fe}^{3+} \mathrm{O}_{1.5}$ (melt), also produces a poorly defined linear trend with a negative slope (Fig. 9a). This could suggest there is large variation in the ratio of activity coefficients for $\mathrm{Al}$ and $\mathrm{Ga}$ relative to other $3+$ cations in the melt with variation in bulk composition or temperature. This might be expected for $\mathrm{Al}$ given that it is a major component of the melt. It is also worth noting that spinels crystallised in studies included by Righter et al. (2006), Leeman (1974), Horn et al. (1994) and Wijbrans et al. (2015) have significantly higher $\mathrm{Al}$ cpfu ( $\mathrm{Al}$ cpfu $=0.82$ in data included from Wijbrans et al. (2015) in comparison to $\mathrm{Al}$ cpfu from 0.1 to 0.2 in this study), which could exert an additional control on spinel-melt partitioning through significantly altering the activity of the substituting cation. 

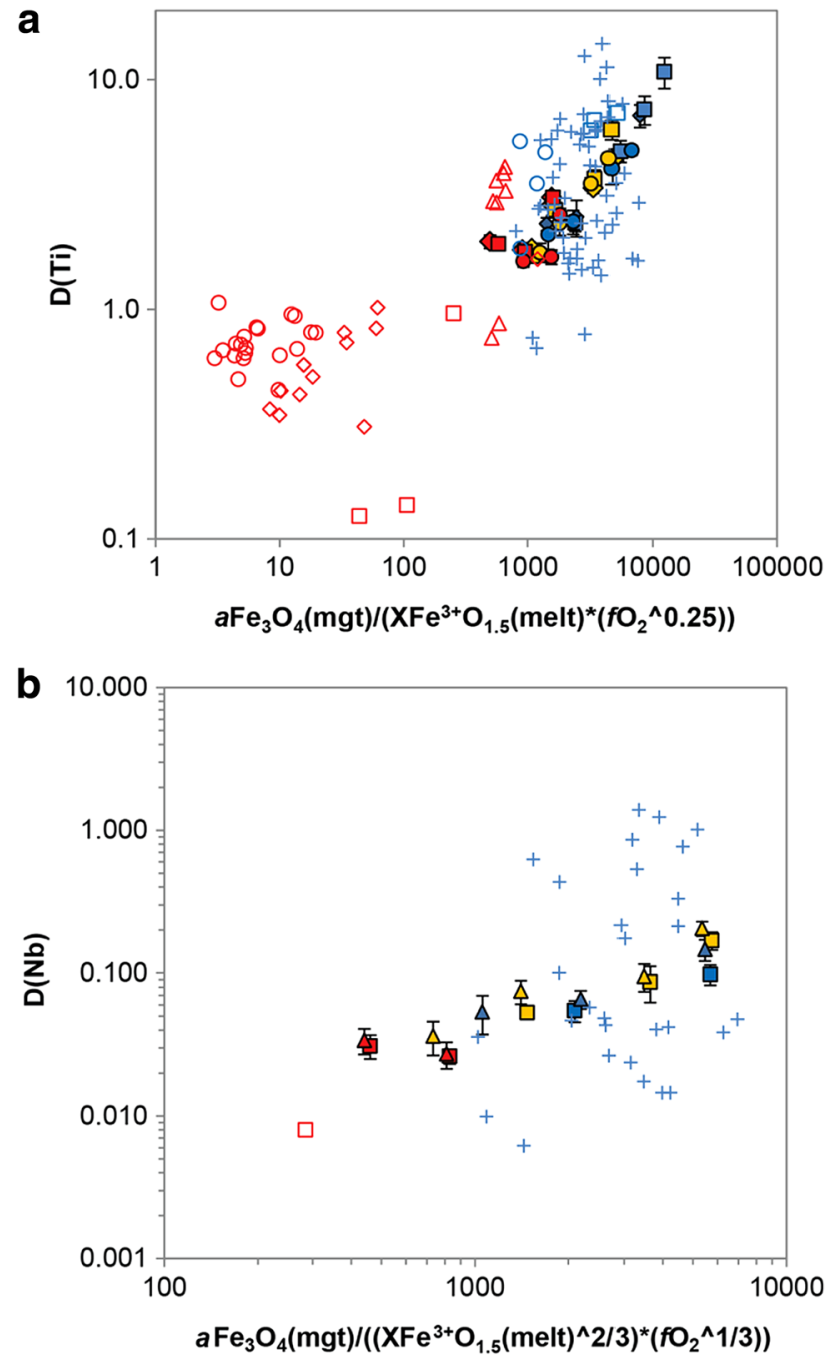

$\diamond$ And-190 $\left(\mathrm{T}=1070^{\circ} \mathrm{C}\right)$
$\diamond$ And-190 $\left(\mathrm{T}=1095^{\circ} \mathrm{C}\right)$
$\diamond$ And-190 $\left(\mathrm{T}=1120^{\circ} \mathrm{C}\right)$
$\square$ And $-190+\mathrm{Fe}_{2} \mathrm{O}_{3}\left(\mathrm{~T}=1070^{\circ} \mathrm{C}\right)$
$\square$ And-190 $+\mathrm{Fe}_{2} \mathrm{O}_{3}\left(\mathrm{~T}=1095^{\circ} \mathrm{C}\right)$
$\square$ And $-190+\mathrm{Fe}_{2} \mathrm{O}_{3}\left(\mathrm{~T}=1120^{\circ} \mathrm{C}\right)$
O JA-1 $+\mathrm{Fe}_{2} \mathrm{O}_{3}\left(\mathrm{~T}=1070^{\circ} \mathrm{C}\right)$
O JA-1 $+\mathrm{Fe}_{2} \mathrm{O}_{3}\left(\mathrm{~T}=1095^{\circ} \mathrm{C}\right)$
O JA-1 $+\mathrm{Fe}_{2} \mathrm{O}_{3}\left(\mathrm{~T}=1120^{\circ} \mathrm{C}\right)$
O Toplis and Corgne $(2002)$ - Ferrobasalt
$\square$ Toplis et al. $(1994)-$ Ferrobasalt
$\triangle$ Righter et al. $(2006)-$ Tholeiite
$\diamond$ Leeman (1974) - Ankaramite
$\square$ Wijbrans et al. (2015) - sp6 Ultramafic (CFMAS)
O Horn et al. $(1994)$ - Alkali Basalt
+ Nielsen et al. (1994)

Fig. 10 a $D$ (Ti) plotted against $a \mathrm{Fe}_{3} \mathrm{O}_{4}(\mathrm{mgt}) /\left[\mathrm{XFe}^{3+} \mathrm{O}_{1.5}(\right.$ melt $) \times$ $\left.\left(f \mathrm{O}_{2}^{0.25}\right)\right]$ and $\mathbf{b} D(\mathrm{Nb})$ as a function of $a \mathrm{Fe}_{3} \mathrm{O}_{4}(\mathrm{mgt}) /\left[\left(\mathrm{XFe}^{3+} \mathrm{O}_{1.5}\right.\right.$ $\left.\left.(\text { melt })^{2 / 3}\right) \times\left(f \mathrm{O}_{2}^{1 / 3}\right)\right] . a \mathrm{Fe}_{3} \mathrm{O}_{4}(\mathrm{mgt})$ approximated using model by O'Neill and Wall (1987) and mole fraction on single-cation basis $\mathrm{XFe}^{3+} \mathrm{O}_{1.5}$ (melt) calculated from values approximated using Kress and Carmichael (1991). Relevant literature data are included for comparison (Toplis et al. 1994; Toplis and Corgne 2002; Nielsen et al. 1994; Righter et al. 2006; Leeman 1974; Horn et al. 1994; Wijbrans et al. 2015). Error bars $=1 \sigma$
Linear relationships can also be produced which describe the partitioning of tetravalent and pentavalent cations as a function of $\left(a \mathrm{Fe} 3 \mathrm{O} 4_{\text {mgt }}\right) /\left(X \mathrm{Fe}^{3+} \mathrm{O}_{1.5 \text { liq }} \times f \mathrm{O}^{0.25}\right)$ and $\left(a \mathrm{Fe} 3 \mathrm{O} 4_{\mathrm{mgt}}\right) /\left(\mathrm{XFe}^{3+} \mathrm{O}_{1.5 \mathrm{liq}}^{2 / 3} \times f \mathrm{O} 2^{1 / 3}\right)$, respectively (Fig. 10). The linear trend for $D(\mathrm{Ti})$ is corroborated by literature data covering different bulk compositions to that studied here. Data from Wijbrans et al. (2015) support the linear trend defined for $D(\mathrm{Nb})$; however, data from Nielsen et al. (1994) do not. It is possible that the contrasting spinel composition affects the mineral-melt partitioning so that this model is only relevant for magnetite-rich spinel.

For the And-190 $+\mathrm{Fe}_{2} \mathrm{O}_{3}$ bulk composition, between $\mathrm{FMQ}+0.2$ and FMQ +3 , the maximum variation in $a \mathrm{Fe}_{3} \mathrm{O}_{4}(\mathrm{mgt}) / \mathrm{XFe}^{3+} \mathrm{O}_{1.5}$ (melt) is between 42.5 and 54.3. The $f \mathrm{O}_{2}$ expression, however, exhibits a much larger variation, and between FMQ $+0.2<f \mathrm{O}_{2}<\mathrm{FMQ}+3,1 /(f$ $\mathrm{O}_{2}^{0.25}$ ) varies between 285.10 and 56.9. Clearly, the oxygen fugacity term $\left(f \mathrm{O}_{2}^{0.25}\right)$ dictates most influence on the partitioning of the tetravalent cations, which could explain the large degree of overlap between datasets for $D(\mathrm{Ti})$ as a function of $f \mathrm{O}_{2}$ (Fig. 5c). In this premise, the partitioning of homovalent tetravalent and higher valence cations, should be easier to predict from the $f \mathrm{O}_{2}$ alone, than cations with variable valence state. For example, $\mathrm{V}$ partitioning is often used as a proxy for $f \mathrm{O}_{2}$ owing to its multivalent character. However, this mixed valency substantially complicates the dependence of its partitioning as a function of $f \mathrm{O}_{2}$. In this premise, in comparison to $\mathrm{V}$, the partitioning behaviour of homovalent tetravalent and pentavalent cations in response to $f \mathrm{O}_{2}$ is easier to predict, and therefore could offer an improved proxy for $f \mathrm{O}_{2}$. Notwithstanding this, it is important to consider that the crystallisation of zircon will strongly influence the concentration of $\mathrm{Zr}$ and $\mathrm{Hf}$ in the melt, which would hinder the use of $\mathrm{Zr}$ and $\mathrm{Hf}$ titanomagnetite-melt partitioning as potential proxies for $f \mathrm{O}_{2}$ in natural systems.

In summary, thermodynamic principles predict linear relationships between titanomagnetite-melt partitioning and the $a \mathrm{Fe}_{3} \mathrm{O}_{4}$ in titanomagnetite and $\mathrm{XFe}^{3+} \mathrm{O}_{1.5}$ and $\mathrm{XFe}^{2+} \mathrm{O}$ in the melt, which are supported by results in this study. Thus, for magnetite-rich spinel we conclude that titanomagnetite-melt partitioning is controlled to a first order by the chemical equilibria associated with a changing melt composition. Notwithstanding this, the activity coefficients, both in spinel and the melt, are expected to vary with changes in the bulk composition of the system. This could exert an additional control on spinel-melt partitioning. Nevertheless, it is difficult to determine whether such changes in partitioning in contrasting bulk compositions to those studied here reflect changes in the activity coefficients in the crystal or melt (O'Neill and Eggins 2002). 

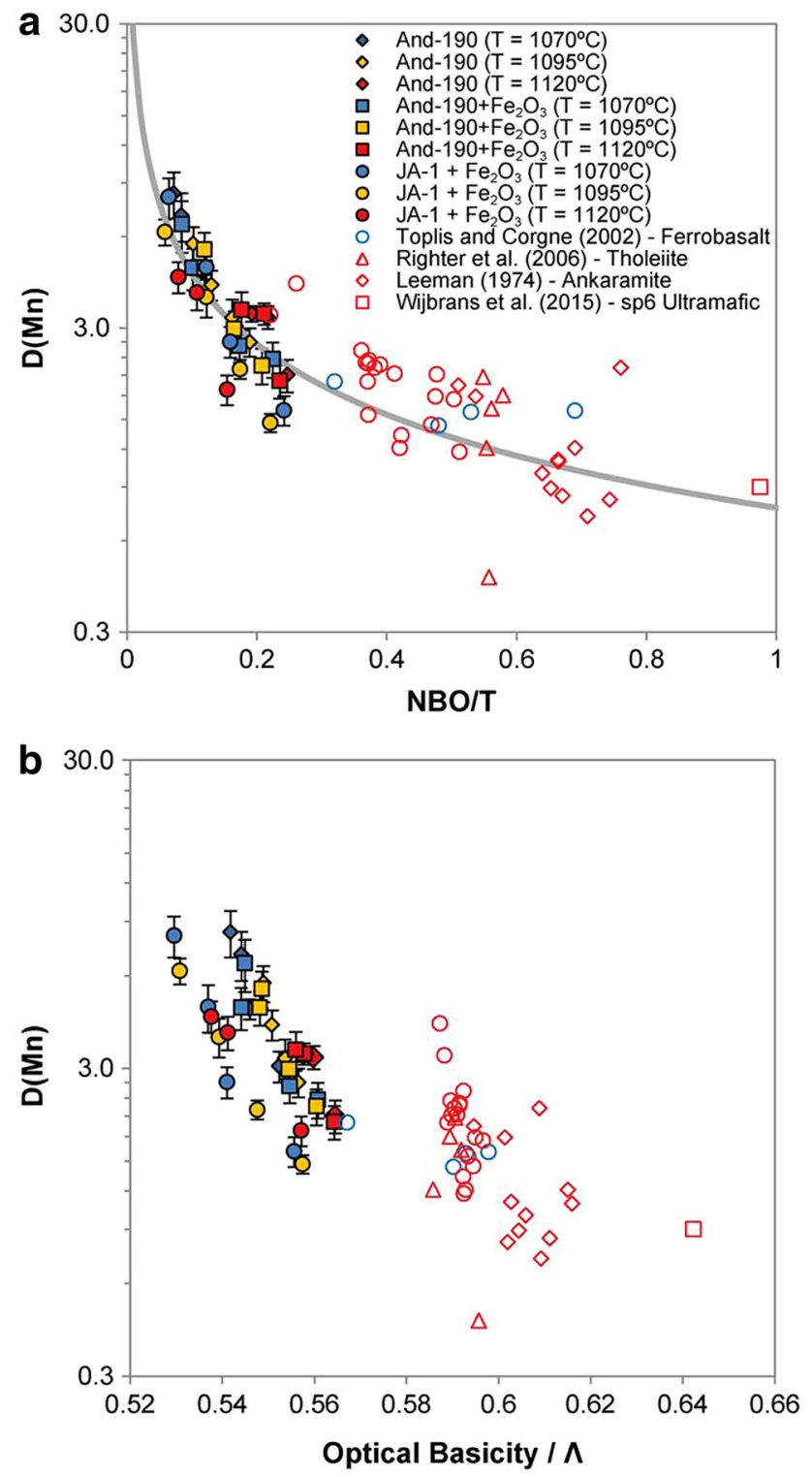

Fig. 11 Titanomagnetite-melt partition coefficients of $\mathrm{Mn}$ versus a NBO/T (calculated as described in Toplis and Corgne (2002)) and b optical basicity ( $\Lambda$-calculated after Duffy 1993). Relevant literature data are included for comparison (Toplis et al. 1994; Toplis and Corgne 2002; Righter et al. 2006; Leeman 1974; Horn et al. 1994; Wijbrans et al. 2015). Solid line represents fit to all data: $D(\mathrm{Mn})=0.77 \times(\mathrm{NBO} / \mathrm{T})^{-0.77}$ with an $R^{2}$ value of 0.81 . Error bars $=1 \sigma$

\section{Melt polymerisation}

A number of previous studies have identified that the degree of melt polymerisation exerts a strong control on the partitioning of elements between crystalline phases and melts (e.g. Kohn and Schofield 1994; Toplis and Corgne 2002; Kushiro and Mysen 2002; Mysen 2007). Melt polymerisation is frequently expressed as $\mathrm{NBO} / \mathrm{T}$ (the molar ratio of non-bridging oxygens to tetrahedrally co-ordinated cations) which can be calculated from the melt composition. With increasing NBO/T, $D(\mathrm{Mg}), D(\mathrm{Mn}), D(\mathrm{Ni}), D(\mathrm{Co})$ and $D(\mathrm{Zn})$ decrease forming well-defined trends, that are an exponential function of melt NBO/T (Fig. 11a). When supplemented by data from Toplis and Corgne (2002), Righter et al. (2006), Leeman (1974), Horn et al. (1994) and Wijbrans et al. (2015), it is clear that this trend is particularly pronounced at $\mathrm{NBO} / \mathrm{T}<0.30$, but flattens at higher values. In highly polymerised melts $D(\mathrm{Mn})$ values up to 8.3 and $D(\mathrm{Mg})$ up to 6.0 are observed; in this region of melt polymerisation, small increases in the degree of polymerisation (decreases in NBO/T) are accompanied by large increases in the partition coefficients.

As has been noted previously for several crystalline phases, $D\left(\mathrm{M}^{2+}\right)$ can be described by the equation $D\left(\mathrm{M}^{2+}\right)=\mathrm{C} .(\mathrm{NBO} / \mathrm{T})^{-\mathrm{X}}$ where $\mathrm{X}$ and $\mathrm{C}$ are constants specific to the partitioning of each metal cation (Kohn and Schofield 1994; Toplis and Corgne 2002). Previous work cautioned the use of this equation at values of $\mathrm{NBO} / \mathrm{T}<0.08$; however, the results of this work suggest that this equation is still valid in this compositional range. Incorporating data from this study with that of previous work (Toplis and Corgne 2002; Toplis et al. 1994; Righter et al. 2006; and Leeman 1974), the following relationships have been derived to predict the titanomagnetite-melt partition coefficients for $\mathrm{Mg}$ and $\mathrm{Mn}$ :

$D(\mathrm{Mg})=0.52 \times(\mathrm{NBO} / \mathrm{T})^{-0.82} R^{2}=0.78$,

$D(\mathrm{Mn})=0.77 \times(\mathrm{NBO} / \mathrm{T})^{-0.77} R^{2}=0.81$.

The other divalent cations also follow a similar trend in terms of NBO/T as could be inferred by the linear correlation of divalent cations with one another (Fig. 4). It has been suggested that more polymerised melts contain fewer potential sites onto which network-modifying cations can partition (Toplis and Corgne 2002). This could result in higher mineral-melt partition coefficients with increasing melt polymerisation for cations that act as network modifiers, notably the divalent cations. However, this does not explain why the relationship is exponential. Furthermore, there is not an adequate reason to account for the fact that the relationship with $\mathrm{NBO} / \mathrm{T}$ is only observed for the divalent cations, and not the partitioning of other network-modifying cations with different valence states.

The optical basicity $(\Lambda)$ can be used as an alternative, and potentially superior, measure of melt structure which distinguishes different cations with contrasting electron donor power (Duffy 1993). Similar to plotting $D\left(\mathrm{M}^{2+}\right)$ vs. $\mathrm{NBO} / \mathrm{T}$, plotting $D\left(\mathrm{M}^{2+}\right)$ vs. $\Lambda$ generates trends that are an exponential function of $\Lambda$ (Fig. 11b). This trend, however, diverges into two paths at $\Lambda<0.56$, for the dacitic (JA-1) and andesitic (And-190) compositions investigated and 


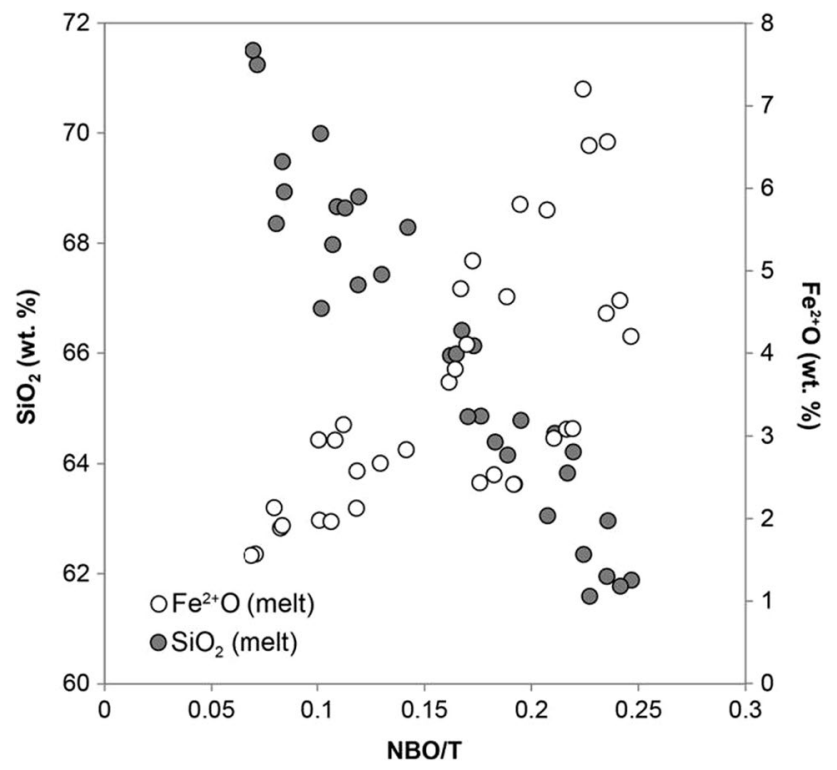

Fig. 12 Melt $\mathrm{Fe}^{2+} \mathrm{O}\left(\mathrm{wt} \%\right.$ ) and $\mathrm{SiO}_{2}(\mathrm{wt} \%)$ as a function of $\mathrm{NBO} / \mathrm{T}$ (calculated as described in Toplis and Corgne (2002). $\mathrm{Fe}^{2+} \mathrm{O}$ values approximated using Kress and Carmichael (1991)

does not form a single, well-defined trend as observed for NBO/T. The inability of $\Lambda$ to fully describe the partitioning behaviour suggests melt polymerisation is not the dominant control on $D\left(\mathrm{M}^{2+}\right)$. Furthermore, $\mathrm{NBO} / \mathrm{T}$ is a strong function of $\mathrm{Fe}^{2+} \mathrm{O}_{\text {melt }}$ (Fig. 12), with a correlation coefficient between the two variables of 0.72 . Thus, the apparent correlation between the partitioning of divalent cations and NBO/T could in fact be an artefact of the change in $\mathrm{Fe}^{2+} \mathrm{O}_{\text {melt }}$ with increasing $f \mathrm{O}_{2}$. For instance, with increased $f_{2}$, there is an increase in the crystallisation of titanomagnetite, which decreases the concentration $\mathrm{Fe}$ in the melt and hence of $\mathrm{Fe}^{2+} \mathrm{O}_{\text {melt }}$. There is also an increase in the concentration of $\mathrm{SiO}_{2}$ in the melt with increasing $\mathrm{NBO} / \mathrm{T}$ (Fig. 12). The change in melt composition will therefore drive changes in melt structure and NBO/T which generates illusory correlations between partitioning and melt polymerisation. Although there is correlation between melt structure and partitioning, this does not imply causation. Instead, we suggest that thermodynamic equilibria between mineral and melt and its associated changes in $a\left(\mathrm{Fe}^{2+} \mathrm{O}\right)$ and $a\left(\mathrm{Fe}^{3+} \mathrm{O}_{1.5}\right)$ in the melt offer a more accurate explanation of partitioning.

\section{Implications for studying natural systems}

\section{Evidence for redox-sensitive partitioning of isovalent divalent cations in intermediate-silicic bulk systems}

The relationship between $f \mathrm{O}_{2}$ and melt composition has important implications for natural intermediate-silicic

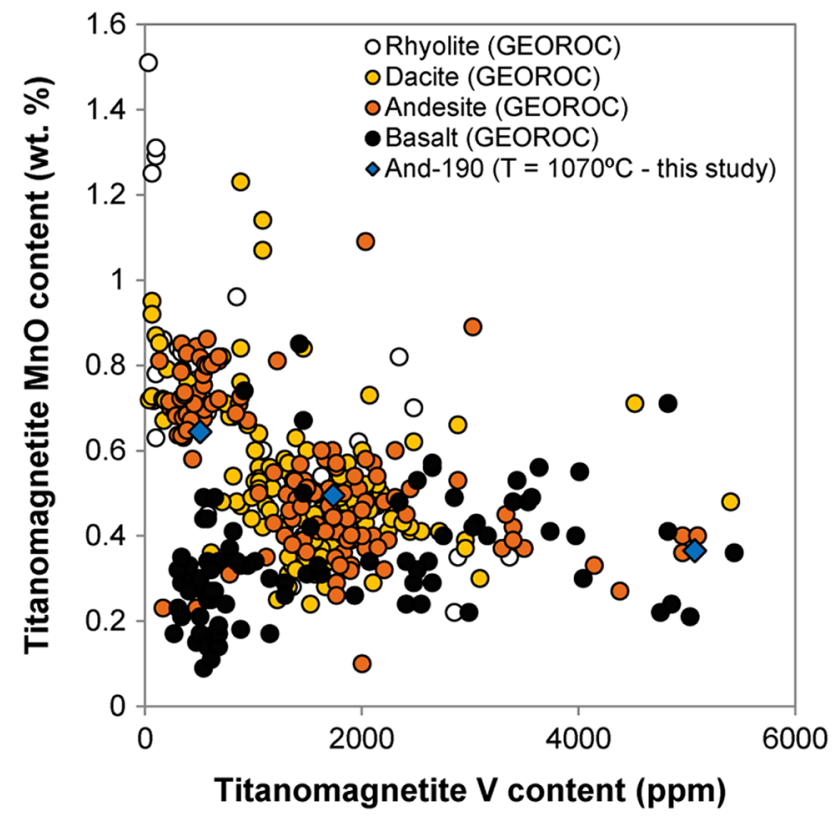

Fig. 13 Titanomagnetite $\mathrm{MnO}$ vs. V contents for rhyolitic, dacitic, andesitic and basaltic rocks from GEOROC (Sarbas and Nohl 2008). Data using And-190 at $1070{ }^{\circ} \mathrm{C}$ (this study) is included for comparison and mimics trend defined by andesite and dacite

magmas. In silicic bulk systems, the increased crystallisation of magnetite with increasing $f \mathrm{O}_{2}$ predominantly drives a decrease in $\mathrm{XFe}^{2+} \mathrm{O}_{\text {melt }}$, with only minor variation in $a \mathrm{Fe}_{3} \mathrm{O}_{4}$ (Table 3). Consequently, the partitioning of divalent cations is indirectly sensitive to changes in $f \mathrm{O}_{2}$, particularly between FMQ +0.2 and FMQ +3 . The partitioning of divalent cations into other cocrystallising mafic phases, bearing a significant amount of ferrous iron, could also be indirectly sensitive to $f \mathrm{O}_{2}$ for the same reasons. Fractionation of other phases, such as silicate phases, could also exert a control on melt composition although, because the crystallisation of magnetite occurs relatively abruptly in comparison to silicate phases and is particularly sensitive to $f \mathrm{O}_{2}$, magnetite crystallisation can trigger quite sudden changes in melt chemistry, particularly at high $f \mathrm{O}_{2}$ (e.g. $f \mathrm{O}_{2}>$ FMQ +2 ).

There is evidence for a systematic increase in $D\left(\mathrm{M}^{2+}\right)$ with increasing $f \mathrm{O}_{2}$ in natural intermediate-silicic rocks. Using the GEOROC database (Sarbas and Nohl 2008), data from titanomagnetite worldwide was filtered and sorted into categories based on host rock: basalt, andesite, dacite and rhyolite. Despite the complexity of its dependence, the partitioning of $\mathrm{V}$ into titanomagnetite has been shown to be a relatively good, qualitative proxy for the $\mathrm{fO}_{2}$ (e.g. this study; Righter et al. 2006; Toplis and Corgne 2002). Plotting V content of magnetite as a redox proxy against divalent cations, such as $\mathrm{Mn}$, indicates that at $\mathrm{V}$ contents less than approximately $1200 \mathrm{ppm}$, with 
decreasing $\mathrm{V}$ content, the $\mathrm{MnO}$ content of titanomagnetite increases in rhyolitic, dacitic and andesitic rocks. In titanomagnetite from basaltic rocks, however, there is no apparent increase in $\mathrm{MnO}$ content with decreasing $\mathrm{V}$ content. This suggests that $\mathrm{Mn}$ partitioning is indirectly sensitive to $f \mathrm{O}_{2}$ as a result of the influence of $f \mathrm{O}_{2}$ on magnetite crystallisation and its implications for $a \mathrm{Fe}_{3} \mathrm{O}_{4 \mathrm{mgt}} / X$ $\mathrm{Fe}^{2+} \mathrm{O}_{\text {melt }}$. It is interesting to note that the data from And190 in this study follow a similar trend to natural titanomagnetite data from andesitic and dacitic rocks (Fig. 13). Magnesium does not produce a trend of increasing titanomagnetite-melt partitioning with decreasing $\mathrm{V}$ content, but this is unsurprising given its incorporation as a major component in other crystallising phases. There is insufficient data in the GEOROC database to produce similar trends for other divalent cations at present.

\section{Redox-sensitive trace-element ratios in magnetite}

The relationships between $f \mathrm{O}_{2}$ and our experimentally determined titanomagnetite-melt partition coefficients of redox-sensitive elements could be used to estimate the $f \mathrm{O}_{2}$ of natural magmas, but only if the composition of the titanomagnetite and the melt from which it crystallised are known. Melt inclusions, hosted within a titanomagnetite grain, could be reasonably assumed to represent the melt from which the crystal grew. However, at magmatic temperatures, lattice diffusion through the host mineral has been shown to be sufficiently rapid to alter the original chemical composition of melt inclusions, including elements not compatible in the host minerals (Spandler et al. 2007; Spandler and O'Neill 2010). In addition to this, melt inclusions are often difficult to find, or are too small to analyse using LA-ICP-MS. Collectively, this thwarts determination of the melt composition using melt inclusions.

Without an accurate means to measure the melt composition, relative redox indicators, using just the spinel composition alone, have been suggested as a means to estimate the $f \mathrm{O}_{2}$ in natural systems (Wijbrans et al. 2015). For example, the ratio of a redox-sensitive element to an element that does not change partitioning behaviour as a function of all other parameters (e.g. melt compositions, crystal composition, temperature and $f \mathrm{O}_{2}$ ) could be used. Furthermore, the bulk partition coefficients of the denominator element should be close to 1 , so that its relative abundance is not strongly influenced by crystallisation of other mineral phases. On this basis, Wijbrans et al. (2015) suggested the use of $\mathrm{Mo} / \mathrm{Ga}$ and $\mathrm{V} / \mathrm{Ni}$ in spinel as possible relative redox monitors. In support of this, within the range of conditions studied here, the titanomagnetitemelt partitioning behaviours of Mo and $\mathrm{V}$ are redox sensitive, whereas the partitioning of $\mathrm{Ga}$ remains relatively insensitive to all parameters. In an intermediate-silicic bulk system, however, we have shown that the partitioning of $\mathrm{Ni}$ is sensitive to $f \mathrm{O}_{2}$ and temperature. Furthermore, when including data from other studies, it is apparent that $\mathrm{Ga}$ is more strongly partitioned in Cr-rich spinel crystallised at higher temperature $\left(T>1250{ }^{\circ} \mathrm{C}\right.$; e.g. Horn et al. (1994)), which negates the use of Ga in systems crystallising over a large range of compositions and temperatures. Notwithstanding this, as far as we are aware, $\mathrm{Ga}$ offers the best possible element for the denominator in a relative redox ratio and could be used in conjunction with redox-sensitive elements such as $\mathrm{V}$ to qualitatively approximate the $f \mathrm{O}_{2}$ in natural systems. In addition to $\mathrm{V}$ and Mo, titanomagnetite-melt partitioning of $\mathrm{Nb}$ and $\mathrm{Ta}$ is also sensitive to $f \mathrm{O}_{2}$ whilst the concentration of $\mathrm{Nb}$ and Ta is relatively unaffected by fractionation of other cocrystallising phases in arc magmas; thus $\mathrm{Nb} / \mathrm{Ga}$ and $\mathrm{Ta} /$ $\mathrm{Ga}$ in titanomagnetite may also be effective relative redox monitors for natural arc magmas. Nevertheless, the use of such relative redox indicator ratios is yet to be tested comprehensively in natural systems.

\section{Conclusions}

Although melt structure has been invoked as the dominant factor controlling the mineral-melt partitioning of divalent cations, we suggest that thermodynamic equilibria between mineral and melt species offer a more rigorous explanation of partitioning, whereby the mechanism of incorporation is controlled by exchange reactions, rather than the site in a variably polymerised melt. Titanomagnetite-melt partitioning of divalent cations has been shown to be a function of $a \mathrm{Fe}_{3} \mathrm{O}_{4 \mathrm{mgt}} / a \mathrm{FeO}$ melt . With increasing $f \mathrm{O}_{2}$, there is a decrease in $\mathrm{Fe}^{2+} \mathrm{O}_{\text {melt }}$ as a result of the increasing proportion of magnetite and increasing $\mathrm{Fe}^{3+} / \Sigma \mathrm{Fe}$ of the system. For many elements, these relationships break down for spinel compositions containing lower fractions of $\mathrm{Fe}_{3} \mathrm{O}_{4}$ than those of this study. This may plausibly be due to changing activity-composition relations in either the spinel, or in the melt. Separating these variables in mineral/melt partitioning studies is in general difficult or even impossible, and other experimental or theoretical information is required (O’Neill and Eggins 2002). However, in an andesitic bulk system, there is only a minor variation in the molar proportion of $\mathrm{Fe}_{3} \mathrm{O}_{4}$ in titanomagnetite with increasing $f \mathrm{O}_{2}$. As a result, in such systems there are large increases in $a \mathrm{Fe}_{3} \mathrm{O}_{4 \mathrm{mgt}} / a \mathrm{Fe}^{2+} \mathrm{O}_{\text {melt }}$ with increasing $f \mathrm{O}_{2}$, and the variation in titanomagnetite-melt partitioning of divalent cations is sufficiently pronounced that it may be confidently ascribed to this factor. In mafic systems, by contrast, there is less variation in $a \mathrm{Fe}_{3} \mathrm{O}_{4 \mathrm{mgl}} / a \mathrm{FeO}$ melt with $f_{2}$ because 
keeping spinel on the liquidus with decreasing $f \mathrm{O}_{2}$ requires a large decrease in the $\mathrm{Fe}_{3} \mathrm{O}_{4}$-content of the spinel. Hence the ratio $a \mathrm{Fe}_{3} \mathrm{O}_{4 \mathrm{mgt}} / a \mathrm{Fe}^{2+} \mathrm{O}_{\text {melt }}$ does not change as much. Consequently, the other factors influencing titanomagnetite-melt partitioning of divalent cations become relatively more important.

Acknowledgements This work was financially supported by the Imperial PhD Scholarship Scheme. We thank Jack Nolan for providing the And-190 starting material, Antony Burnham and Helen Halse for assistance with operating the 1-atm furnace, John Spratt for help with EPMA, and Clara Wilkinson and Elly Harman for assistance with LA-ICP-MS.

Open Access This article is distributed under the terms of the Creative Commons Attribution 4.0 International License (http://creativecommons.org/licenses/by/4.0/), which permits unrestricted use, distribution, and reproduction in any medium, provided you give appropriate credit to the original author(s) and the source, provide a link to the Creative Commons license, and indicate if changes were made.

\section{References}

Burnham AD, Berry AJ, Halse HR, Schofield PF, Cibin G, Mosselmans JFW (2015) The oxidation state of europium in silicate melts as a function of oxygen fugacity, composition and temperature. Chem Geol 411:248-259

Dare SAS, Barnes SJ, Beaudoin G (2012) Variation in trace element content of magnetite crystallized from a fractionating sulfide liquid, Sudbury, Canada: implications for provenance discrimination. Geochim Cosmochim Acta 88:27-50. doi:10.1016/j. gca.2012.04.032

Dare SAS, Barnes SJ, Beaudoin G, Meric J, Boutroy E, PotvinDoucet C (2014) Trace elements in magnetite as petrogenetic indicators. Miner Deposita 49:785-796. doi:10.1007/ s00126-014-0529-0

Dieckmann R (1982) Defects and cation diffusion in magnetite (IV): nonstoichiometry and point defect structure of magnetite $\left(\mathrm{Fe}_{3}-\delta \mathrm{O}_{4}\right)$. Ber Bunsenges Phys Chem 86:112-118

Doyle CD, Naldrett AJ (1987) Ideal mixing of divalent cations in mafic magma. II. The solution of $\mathrm{NiO}$ and the partitioning of nickel between coexisting olivine and liquid. Geochim Cosmochim Acta 51:213-219

Duffy JA (1993) A review of optical basicity and its applications to oxidic systems. Geochim Cosmochim Acta 57:3961-3970

Dupuis C, Beaudoin G (2011) Discriminant diagrams for iron oxide trace element fingerprinting of mineral deposit types. Miner Deposita 46:319-335. doi:10.1007/s00126-011-0334-y

Ewart A, Griffin WL (1994) Application of proton-microprobe data to trace-element partitioning in volcanic-rocks. Chem Geol 117:251-284. doi:10.1016/0009-2541(94)90131-7

Gill J (1981) Orogenic andesites and plate tectonics. Springer, New York

Hemmingway BS (1990) Thermodynamic properties for bunsenite, $\mathrm{NiO}$, magnetite, $\mathrm{Fe} 3 \mathrm{O} 4$, hematite, $\mathrm{Fe} 2 \mathrm{O} 3$, with comments on selected buffer reactions. American Mineralogist 75:781-790

Henderson P, Nolan J, Cunningham GC, Lowry RK (1985) Structural controls and mechanisms of diffusion in natural silicate melts. Contrib Mineral Petrol 89:263-272. doi:10.1007/bf00379459
Horn I, Foley SF, Jackson SE, Jenner GA (1994) Experimentally determined partitioning of high-field strength-elements and selected transition-elements between spinel and basaltic melt. Chem Geol 117:193-218. doi:10.1016/0009-2541(94)90128-7

Jacob K, Fitzner K, Alcock C (1977) Activities in the spinel solid solution, phase equilibria and thermodynamic properties of ternary phases in the system Cu-Fe-0. Metall Trans B 8:451-460

Katayama K (1987) Phase equilibria in the Fe-Nb-O system at $1200^{\circ}$ C. J Solid State Chem 69:101-108

Katayama I, Matsuda T, Kazuka Z (1980) Thermodynamic Study on Fe3O4-CuFe2O4 System by E. M. F method. Technol Rep Osaka Univ 30:385-390

Katkov A, Lykasov A (2003) Spinel phase relations in the $\mathrm{Fe}_{3} \mathrm{O}_{4}$ $\mathrm{CuFe}_{2} \mathrm{O}_{4}$ system. Inorg Mater 39:171-174

Kohn SC, Schofield PF (1994) The importance of melt composition in controlling trace-element behavior: an experimental-study of Mn and $\mathrm{Zn}$ partitioning between forsterite and silicate melts. Chem Geol 117:73-87. doi:10.1016/0009-2541(94)90122-8

Kress VC, Carmichael ISE (1991) The compressibility of silicate liquids containing $\mathrm{Fe}_{2} \mathrm{O}_{3}$ and the effect of composition, temperature, oxygen fugacity and pressure on their redox states. Contrib Mineral Petrol 108:82-92. doi:10.1007/Bf00307328

Kushiro I, Mysen BO (2002) A possible effect of melt structure on the $\mathrm{Mg}-\mathrm{Fe}^{2+}$ partitioning between olivine and melt. Geochim Cosmochim Acta 66:2267-2272. doi:10.1016/ S0016-7037(01)00835-3

Leeman WP (1974) Experimental determination of the partitioning of divalent cations between olivine and basaltic liquid. $\mathrm{PhD}$ Thesis, University of Oregon

Liu X, Xiong X, Audétat A, Li Y, Song M, Li L, Sun W, Ding X (2014) Partitioning of copper between olivine, orthopyroxene, clinopyroxene, spinel, garnet and silicate melts at upper mantle conditions. Geochim Cosmochim Acta 125:1-22

Liu X, Xiong X, Audétat A, Li Y (2015) Partitioning of Cu between mafic minerals, $\mathrm{Fe}-\mathrm{Ti}$ oxides and intermediate to felsic melts. Geochim Cosmochim Acta 151:86-102

Luhr JF, Carmichael IS (1980) The colima volcanic complex, Mexico. Contrib Miner Petrol 71:343-372

Mallmann G, O'Neill HSC (2009) The crystal/melt partitioning of $\mathrm{V}$ during mantle melting as a function of oxygen fugacity compared with some other elements (Al, P, Ca, Sc, Ti, Cr, Fe, $\mathrm{Ga}, \mathrm{Y}, \mathrm{Zr}$ and $\mathrm{Nb}$ ). J Petrol 50:1765-1794

Mysen B (2007) Partitioning of calcium, magnesium, and transition metals between olivine and melt governed by the structure of the silicate melt at ambient pressure. Am Mineral 92:844-862. doi:10.2138/am.2007.2260

Nadoll P, Angerer T, Mauk JL, French D, Walshe J (2014) The chemistry of hydrothermal magnetite: a review. Ore Geol Rev 61:1-32. doi:10.1016/j.oregeorev.2013.12.013

Nickel EH (1973) The new mineral cuprospinel $\left(\mathrm{CuFe}_{2} \mathrm{O}_{4}\right)$ and other spinels from an oxidized ore dump at Baie Verte, Newfoundland. Can Mineral 11:1003-1007

Nielsen RL, Beard JS (2000) Magnetite-melt HFSE partitioning. Chem Geol 164:21-34. doi:10.1016/s0009-2541(99)00139-4

Nielsen RL, Forsythe LM, Gallahan WE, Fisk MR (1994) Majorelement and trace-element magnetite-melt equilibria. Chem Geol 117:167-191. doi:10.1016/0009-2541(94)90127-9

O'Neill HSC, Berry AJ (2006) Activity coefficients at low dilution of $\mathrm{CrO}, \mathrm{NiO}$ and $\mathrm{CoO}$ in melts in the system $\mathrm{CaO}-\mathrm{MgO}-\mathrm{Al} 2$ $\mathrm{O} 3-\mathrm{SiO} 2$ at $1400 \mathrm{C}$ : using the thermodynamic behaviour of transition metal oxides in silicate melts to probe their structure. Chem Geol 231:77-89

O’Neill HSC, Navrotsky A (1983) Simple spinels; crystallographic parameters, cation radii, lattice energies, and cation distribution. Am Miner 68:181-194 
O'Neill HSC, Navrotsky A (1984) Cation distributions and thermodynamic properties of binary spinel solid solutions. Am Mineral 69:733-753

O'Neill HSC, Eggins SM (2002) The effect of melt composition on trace element partitioning: an experimental investigation of the activity coefficients of $\mathrm{FeO}, \mathrm{NiO}, \mathrm{CoO}, \mathrm{MoO} 2$ and $\mathrm{MoO} 3$ in silicate melts. Chem Geol 186:151-181. doi:10.1016/ s0009-2541(01)00414-4

O'Neill HSC, Wall V (1987) The Olivine-Orthopyroxene-Spinel oxygen geobarometer, the nickel precipitation curve, and the oxygen fugacity of the Earth's Upper Mantle. J Petrol 28:1169-1191

Righter K, Leeman WP, Hervig RL (2006) Partitioning of Ni, Co and $\mathrm{V}$ between spinel-structured oxides and silicate melts: importance of spinel composition. Chem Geol 227:1-25. doi:10.1016/j.chemgeo.2005.05.011

Ripley EM, Brophy JG (1995) Solubility of copper in a sulfur-free mafic melt. Geochim Cosmochim Acta 59:5027-5030

Sarbas B, Nohl U (2008) The GEOROC database as part of a growing geoinformatics network (abstract). Geoinformatics Conference, Potsdam, Germany

Simon AC, Candela PA, Piccoli PM, Mengason M, Englander L (2008) The effect of crystal-melt partitioning on the budgets of $\mathrm{Cu}, \mathrm{Au}$, and Ag. Am Mineral 93:1437-1448

Spandler C, O’Neill HSC (2010) Diffusion and partition coefficients of minor and trace elements in San Carlos olivine at 1,300 C with some geochemical implications. Contrib Mineral Petrol 159:791-818
Spandler C, O’Neill HSC, Kamenetsky VS (2007) Survival times of anomalous melt inclusions from element diffusion in olivine and chromite. Nature 447:303-306

Toplis M (2005) The thermodynamics of iron and magnesium partitioning between olivine and liquid: criteria for assessing and predicting equilibrium in natural and experimental systems. Contrib Miner Petrol 149:22-39

Toplis MJ, Corgne A (2002) An experimental study of element partitioning between magnetite, clinopyroxene and iron-bearing silicate liquids with particular emphasis on vanadium. Contrib Mineral Petrol 144:22-37. doi:10.1007/s00410-002-0382-5

Toplis MJ, Libourel G, Carroll MR (1994) The role of phosphorus in crystallization processes of basalt: an experimental-study. Geochim Cosmochim Acta 58:797-810. doi:10.1016/0016-7037(94)90506-1

Turnock A (1966) Fe-Nb Oxides: phase Relations at $1180^{\circ}$ C. J Am Ceramic Soc 49:177-180

Wijbrans C, Klemme S, Berndt J, Vollmer C (2015) Experimental determination of trace element partition coefficients between spinel and silicate melt: the influence of chemical composition and oxygen fugacity. Contrib Mineral Petrol 169:1-33

Wu C, Mason TO (1981) Thermopower measurement of cation distribution in magnetite. J Am Ceramic Soc 64:520-522

Zacharias J, Wilkinson J (2007) ExLAM 2000: Excel VBA application for processing of transient signals from laser ablation (LAICP-MS) of fluid inclusions and solid phases (abstract). ECROFIXIX Biennial Conference on European Current Research on Fluid Inclusions, Bern, Switzerland 